Geórgia Reis Prado

\title{
ESTUDO DA RESISTÊNCIA de $D$. radiodurans à ação combinada de RADIAÇÕES IONIZANTES com CAMPOS ELÉTRICOS OU MAGNÉTICOS EXÓGENOS
}

Tese apresentada ao Programa de PósGraduação Interunidades em Biotecnologia USP/Instituto Butantan/IPT para obtenção do título de Doutor em Biotecnologia. 
Geórgia Reis Prado

\section{ESTUDO DA RESISTÊNCIA de $D$. radiodurans à ação combinada de RADIAÇÕES IONIZANTES com CAMPOS ELÉTRICOS OU MAGNÉTICOS EXÓGENOS}

Tese apresentada ao Programa de PósGraduação Interunidades em Biotecnologia USP/Instituto Butantan/IPT para obtenção do título de Doutor em Biotecnologia.

Área de Concentração: Biotecnologia

Orientador: João Dias de Toledo Arruda Neto

Co-orientadora: Soraia Attie Calil Jorge 
DADOS DE CATALOGAÇÃO NA PUBLICAÇÃO (CIP)

Serviço de Biblioteca e Informação Biomédica do

Instituto de Ciências Biomédicas da Universidade de São Paulo

(C) reprodução total

Prado, Geórgia Reis.

Estudo da resistência de $D$. radiodurans à ação combinada de radiações ionizantes com campos elétricos ou magnéticos exógenos / Geórgia Reis Prado. -- São Paulo, 2011.

Orientador: João Dias de Toledo Arruda-Neto.

Tese (Doutorado) - Universidade de São Paulo. Instituto de Ciências Biomédicas. Programa de Pós-Graduação Interunidades em Biotecnologia USP/IPT/Instituto Butantan. Área de concentração: Biotecnologia. Linha de pesquisa: Biofísica celular.

Versão do título para o inglês: Study of resistance of $D$. radiodurans to the combined action of ionizing radiation with an electric or magnetic fields exogenous.

Descritores: 1. Biofísica 2. Radiações ionizantes 3. Campos elétricos e magnéticos 4 . D. radiodurans 5 . Bactérias radioresistentes 6. DNA I. Arruda-Neto, João Dias de Toledo II. Universidade de São Paulo. Instituto de Ciências Biomédicas. Programa de Pós-Graduação Interunidades em Biotecnologia USP/IPT/Instituto Butantan III. Título. 


\section{UNIVERSIDADE DE SÃO PAULO}

Programa de Pós-Graduação Interunidades em Biotecnologia

Universidade de São Paulo, Instituto Butantan, Instituto de Pesquisas Tecnológicas

Candidato(a): $\quad$ Geórgia Reis Prado.

Título da Tese: $\quad$ Estudo da resistência de $D$. radiodurans à ação combinada de radiações ionizantes com campos elétricos ou magnéticos exógenos.

Orientador(a): $\quad$ João Dias de Toledo Arruda-Neto.

A Comissão Julgadora dos trabalhos de Defesa da Tese de Doutorado, em sessão pública realizada a considerou

\section{( ) Aprovado(a) ( ) Reprovado(a)}

$\begin{array}{ll}\text { Examinador(a): } & \begin{array}{l}\text { Assinatura: } \\ \text { Nome: ....... } \\ \\ \text { Instituição: }\end{array} \\ \text { Examinador(a): } & \begin{array}{l}\text { Assinatura: } \\ \text { Nome: ....... } \\ \text { Instituição: }\end{array} \\ \text { Examinador(a): } & \text { Assinatura: } \\ & \text { Nome: ........ } \\ & \text { Instituição: } \\ \text { Examinador(a): } & \begin{array}{l}\text { Assinatura: } \\ \text { Nome: ........ }\end{array} \\ & \text { Instituição: } \\ & \text { Assinatura: } \\ \text { Presidente: } & \text { Nome: ........ } \\ & \text { Instituição: }\end{array}$ 


\section{CERTIFICADO DE ISENÇÃO}

Certificamos que o Protocolo CEP-ICB No 242/08, referente ao projeto intitulado: "Estudo da resistência de D.radiodurans a radiaģão gama, nêutrons e alfas - simulação e proposta de uma nova radioterapia de câncer" sob a responsabilidade de Geórgia Reis Prado, foi analisado na

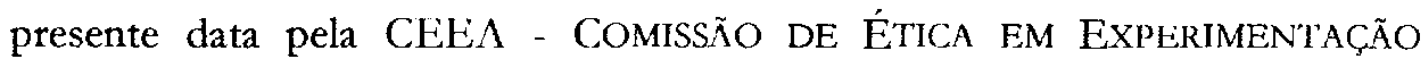
ANIMAL e pela CEPSH - COMISSÃo DE ÉtTiCa EM PESQUISA COM SERES HUMANOS, tendo sido deliberado que o referido projeto não envolve manipulação animal ou humana que justifique uma aprovação quanto aos princípios éticos exigidos por ambas as Comissões.

São Paulo, 19 de março de 2008.

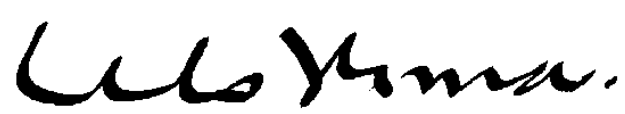

PROF. DR. WO'THAN TAVARFS DE IIMA Coordenador da CEEA - ICB/USP

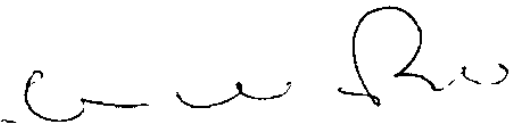

Prof. DR. LuIz Vicente Rizzo Coordenador da CEPsh - ICB/USP 
Fu sou aquela mulher que fez a escalada da montanha da vida, removendo pedras e plantando flores.

(Cora Coralina) 


\section{AGRADECIMENTOS}

A realização deste trabalho contou com o apoio financeiro da Comissão de Energia Nuclear - CNEN e da Fundação de Amparo à Pesquisa do Estado de São Paulo - FAPESP.

Ao meu orientador Professor João Arruda pelo incentivo, por acreditar no meu potencial e saber que por mais que a saudade de casa fosse grande eu jamais desistiria.

A Thati (Thatiane Mendonça) por todo carinho, paciência e cumplicidade durante os dois anos de realização dos meus experimentos. Sua ajuda foi mais que fundamental neste trabalho.

Aos professores e colaboradores José Gregório e Luiziana Ferreira por acreditarem na minha linha de pesquisa e pela confiança em ceder o laboratório de microbiologia a uma Física.

A minha co-orientadora Soraia Attie Calil Jorge pela compreensão e carinho, fundamentais ao meu doutoramento.

Aos técnicos do IPEN Carlos Gaia e Elizabeth Somessari pela competência, disponibilidade, carinho e cuidado em todos os ensaios realizados.

A Deus por ter estado sempre ao meu lado me dando força e coragem, sempre.

Aos meus pais Valmi e Amines que foram capazes de renunciar seus sonhos para que eu realizasse os meus.

A minha querida avó Amélia (in memorian) que faleceu durante meu doutoramento e fazia questão em dizer que eu era a única Doutora da família; e a minha avó Valdeni por tanto amor e carinho. 
Aos queridos técnicos da Física Cacá, Juliana, Marcelo e Roberto pela amizade, e em especial meu queridos amigos Edu e Eliana por tanto carinho.

Cada um, ao seu modo, contribuiu para que eu pudesse encontrar a força e o incentivo necessários para transpor os obstáculos e as dificuldades encontradas. Por isso, aqui vai meu sincero agradecimento a todos que me ajudaram, de alguma forma, a realizar esse trabalho. 
Meu amor, volte logo para casa, nós precísamos de você.

(Minha avó, Valdeni) 


\section{RESUMO}

PRADO, G. R. Estudo da resistência de $D$. radiodurans à ação combinada de radiações ionizantes com campos elétricos ou magnéticos exógenos. 2011. 200 f. Tese (Doutorado em Biotecnologia) - Instituto de Ciências Biomédicas, Universidade de São Paulo, São Paulo, 2011.

O princípio básico da radioterapia é o de maximizar o dano no tumor e de minimizálo nos tecidos sadios vizinhos. Diversas estratégias têm sido realizadas com o intuito de aumentar a radiossensibilidade celular, entre elas a utilização de campos exógenos (campos elétricos e magnético). Neste trabalho estudamos a resistência de Deinococcus radiodurans à ação combinada de radiações convencionais, não convencionais e agentes externos. A $D$. radiodurans é uma bactéria que se destaca pela habilidade extraordinária em suportar efeitos letais e mutagênicos de agentes prejudiciais ao DNA, particularmente a radiação ionizante como gamas e UV, sendo tolerante a este tipo de estresse. Devido a sua elevada radioresistência e rápido crescimento, a $D$. radiodurans tem sido utilizada como modelo de estudo de reparo. Peculiaridades associadas à radioresistência nas fases exponencial e estacionária foram identificadas a partir de curvas de crescimento. Com a obtenção de curvas de sobrevivência foram obtidas informações quanto à radiossensibilidade. Com gamas, a $D$. radiodurans apresentou um ombro de reparo de 2 e $8 \mathrm{kGy}$ nas fases exponencial e estacionária, respectivamente. Nas irradiações com gamas e ajuste da suspensão celular manifestou-se radioresistência similar em ambas as fases de crescimento. Em exposições ao campo elétrico após irradiações com gamas, a $D$. radiodurans apresentou em ambas as fases redução do ombro de reparo. $\mathrm{O}$ ombro de reparo foi de 1 e 4kGy nas fases exponencial e estacionária, respectivamente. Nas exposições ao campo magnético, obtivemos um ombro de 4kGy na fase exponencial e de 6kGy na fase estacionária. Em irradiações com elétrons o ombro de reparo na fase exponencial foi completamente eliminado e na fase estacionária foi de apenas $1 \mathrm{kGy}$. Este trabalho revelou novas e importantes informações referentes à radioresistência da $D$. radiodurans, além de fornecer subsídios para a melhoria de protocolos de radioterapia em associação com outros agentes físicos exógenos. 
Palavras-chave: D. radiodurans. Radiação gama. Feixes de elétrons. Campos elétrico e magnético. Radiossensibilidade. 


\begin{abstract}
PRADO, G. R. Study of resistance of $D$. radiodurans to the combined action of ionizing radiation with an electric or magnetic fields exogenous. 2011. 200 p. Ph. D. Thesis (Biotechnology) - Instituto de Ciências Biomédicas, Universidade de São Paulo, São Paulo, 2011.
\end{abstract}

The key goal in radiotherapy is to maximize damages in a tumor while minimizing them in nearby health tissues. Several strategies have been worked out toward the enhancement of cellular radiosensibility, as the use of exogenous fields. It is studied in this work the resistance of Deinococcus radiodurans to the combined action of conventional and non conventional radiations, with external agents (electric and magnetic fields). $D$. radiodurans is a bacterium having an extraordinary ability to cope with lethal and mutagenic agents harmful to the DNA, particularly ionizing radiations as gammas and UV. Given its high radioresistance and fast growing, D. radiodurans has been used as solid tumors simulators. Peculiarities associated with radioresistance at the exponential and stationary phases were delineated from growing curves. By measuring survival curves information on radiosensibility was obtained. In gamma irradiation $D$. radiodurans exhibited repairing shoulders of 2 and 8 kGy at the exponential and stationary phases, respectively. When gamma irradiations were combined with expositions to the electric field the repairing shoulders were reduced to 1 and $4 \mathrm{kGy}$ at the exponential and stationary phases, respectively. Radioresistance was similar in both growing phases when the number of cells were approximately equalized in these two processes. On the other hand, when gamma irradiations were combined with expositions to the magnetic field the repairing shoulders were reduced to 4 and $6 \mathrm{kGy}$ at the exponential and stationary phases, respectively. In irradiations with electron beams the repairing shoulder at the exponential phase was totally depleted, while at the stationary phase it was only 1 kGy. The findings of this work revealed new and important information on the radioresistance of $D$. radiodurans, while providing hints to the improvement of radiotherapy protocols in association with exogenous physical agents.

Key-words: D. radiodurans. Gamma radiation. Electron beams. Electric and magnetic fields. Radiosensibility. 


\section{LISTA DE FIGURAS}

Figura 1: Faixas das radiações $\alpha, \beta$ e $\gamma$

Figura 2: (a) Representação pictórica do processo de reconhecimento de um DSB por proteínas de reparo. Usualmente essas proteínas possuem grandes momentos de dipolo $\vec{p}$ (representado em $b$ com mais detalhes), que se orientam na direção do sítio danificado pela ação de um campo elétrico estático e endógeno $\left(\vec{E}_{d s}\right)$, campo esse produzido pelo desbalanço de cargas elétricas na dupla fita danificada. (c) Um campo elétrico externo $\left(\vec{E}_{e x t}\right)$ mais intenso do que $\left(\vec{E}_{d s}\right)$ reorientaria o deslocamento das proteínas de reparo ao longo de sua direção impedindo, assim, a consecução do reparo.

Figura 3: Esquema de ação do campo magnético em cargas em movimento: Efeito inibidor do deslocamento de moléculas dipolares provocado pela ação de um campo magnético. A - Proteínas que apresentam seus momentos de dipolo $\vec{p}$ (representado em B com mais detalhes) orientados na direção do sítio danificado (dupla-quebra) pelo campo elétrico $\overrightarrow{E_{d s}}$. C - Um campo magnético externo $\left(B_{\text {ext }}\right)$ induz um binário de forças nas proteínas que se deslocam em direção ao sítio danificado, fazendo-as girar centradas em uma mesma posição. 30

Figura 4: Representação pictória do desdobramento da ATM (b e c) acionado por um pulso elétrico gerando DSB (a), e danos causados pelo campo elétrico - local danificado e proteínas-alvo (c, d).

Figura 5: 1- Representação da curva de sobrevivência da $D$. radiodurans (quadrados) e da E. coli (diamantes) exposta a radiação gamas. 2 Representação da curva de sobrevivência da $D$. radiodurans (quadrados) e da $E$. coli (diamantes) exposta a radiação UV.

Figura 6: Montagem do experimento para a determinação da curva de crescimento da $D$. radiodurans e E. coli. .45

Figura 7: Diluições seriadas. .46

Figura 8: Colônias da $D$. radiodurans. 46

Figura 9: Esquema de preparação das culturas para irradiações. .48

Figura 10: Esquema das irradiações para as linhagens bacterianas em estudo. ....49

Figura 11: Irradiador Gammacel, em detalhe o painel de controle 52

Figura 12: A) Abertura do compartimento em que o material irradiado foi depositado; B) Geometria das amostras no irradiador de $\mathrm{Co}_{60}$. As amostras ficaram num plano horizontal e foram retiradas à medida que acumulavam as 
Figura 13: A) Arranjo do campo elétrico e B) Localização dos tubos com as amostras de $D$. radiodurans submetidas ao campo elétrico....................................54

Figura 14: Capacitor plano de chapas paralelas do Campo Elétrico carregado com cargas de sinais opostos através de um gerador.

Figura 15: Direcionamento do campo elétrico entre um capacitor de chapas planas paralelas. .55

Figura 16: Localização dos tubos com as amostras de $D$. radiodurans submetidas ao campo magnético. .55

Figura 17: Direcionamento do campo magnético e localização das amostras. 56

Figura 18: Irradiador de elétrons (LINAC). A) Esteira por onde as amostras deslizam até o feixe: B) Posição das amostras, abaixo do feixe de elétrons.

Figura 19: Curvas de crescimento da $D$. radiodurans e $E$. coli, obtidas por medidas de DO e incerteza de $0,001 \%$.

Figura 20: Curvas de crescimento da $D$. radiodurans e $E$. coli, obtidas por medidas de UFC/ml.

Figura 21: Curvas de sobrevivência da $D$. radiodurans nas fases estacionária e exponencial sob a ação de radiação gama. Inserção: Curvas de sobrevivência da $D$. radiodurans nas fases estacionária e exponencial sob a ação de radiação gama, escala linear-log.

Figura 22: Curvas de sobrevivência da $E$. coli nas fases estacionária e exponencial sob a ação de radiação gama. Inserção: Curvas de sobrevivência da $E$. coli fases estacionária e exponencial sob a ação de radiação gama, escala linear-log.

Figura 23: Curvas de sobrevivência da $D$. radiodurans nas fases estacionária e exponencial sob a ação de radiação gama com ajuste na suspensão celular. Inserção: Curvas de sobrevivência da $D$. radiodurans fases estacionária e exponencial sob a ação de radiação gama com ajuste da suspensão celular, escala linear-log. .66

Figura 24: Curvas de sobrevivência da $D$. radiodurans na fase estacionária, sob a ação de radiação gama e radiação gama + campo elétrico de $10 \mathrm{~h}$. Inserção: Gráfico Relativo $(\nu+\mathrm{CE} / \nu$ - detalhes no texto) da $D$. radiodurans na fase estacionária, sob a ação radiação gama combinada com campo elétrico de $10 \mathrm{~h}$. 68

Figura 25: Curvas de sobrevivência da $D$. radiodurans na fase exponencial, sob a ação de radiação gama e radiação gama + campo elétrico de $10 \mathrm{~h}$. Inserção: Curvas de sobrevivência da $D$. radiodurans na fase 
exponencial, sob a ação de radiação gama e radiação gama + campo elétrico de $10 \mathrm{~h}$, escala linear-log......

Figura 26: Curvas de sobrevivência da $D$. radiodurans nas fases estacionária e exponencial, sob a ação de radiação gama combinada com campo elétrico de $10 \mathrm{~h}$. Inserção: Curvas de sobrevivência da $D$. radiodurans nas fases estacionária e exponencial, sob a ação de radiação gama e radiação gama + campo elétrico de $10 \mathrm{~h}$, escala linear-log. .70

Figura 27: Curva de sobrevivência de $C$. albicans após irradiação e submetida ao campo elétrico. Fração de células sobreviventes (em escala de linearlog) em função da dose de irradiação gama: $I$ = Irradiada e $I+E F=$ Irradiada e submetida ao campo elétrico -1000 Volts/cm.

Figura 28: Esquema ilustrativo do modelo biofísico da ação do CEE aos fragmentos de DNA.

Figura 29: a) Gel de Eletroforese de campo pulsado de: S - S. cerevisiae, C - D. radiodurans não irradiado, 0; 1,5 h; 3 h e 4,5 h após a irradiação com gamas a 7kGy. b) Gráfico: o eixo y representa o tamanho dos fragmentos de DNA de $D$. radiodurans e o eixo horizontal representa o tempo de exposição após a irradiação com gamas a 7kGy. Curva em preto representa o tamanho dos fragmentos de DNA de $D$. radiodurans sem irradiação e a curva em vermelho representa o tamanho dos fragmentos de DNA de $D$. radiodurans irradiada com gamas a $7 \mathrm{kGy} . . .75$

Figura 30: Curvas de sobrevivência da $D$. radiodurans na fase exponencial, sob a ação de radiação gama e radiação gama combinada com campo magnético por $10 \mathrm{~h}$. Inserção: Curvas de sobrevivência da $D$. radiodurans nas fases exponencial, sob a ação de radiação gama e radiação gama + campo magnético de $10 \mathrm{~h}$, escala linear-log. .76

Figura 31: Curvas de sobrevivência da $D$. radiodurans na fase estacionária, sob a ação de radiação gama e radiação gama combinada com campo magnético de 10h. Inserção: Gráfico Relativo $(\gamma+\mathrm{CM} / \gamma)$ da $D$. radiodurans na fase estacionária, sob a ação radiação gama combinada com campo magnético de $10 \mathrm{~h}$.

Figura 32: Esquema ilustrativo do modelo biofísico da ação do CM aos fragmentos de DNA. .79

Figura 33: Curvas de sobrevivência da $D$. radiodurans na fase exponencial e estacionária, sob a ação de elétrons. Inserção: Curvas de sobrevivência da $D$. radiodurans na fase exponencial e estacionária, sob a ação de elétrons, escala linear-log.

Figura 34: Curvas de sobrevivência da $D$. radiodurans na fase exponencial, sob a ação de gama e elétrons. Inserção: Curvas de sobrevivência da $D$. radiodurans na fase exponencial, sob a ação gama e elétrons, escala linear-log. 
Figura 35: Curvas de sobrevivência da $D$. radiodurans na fase estacionária, sob a ação de gama e elétrons. Inserção: Curvas de sobrevivência da $D$. radiodurans na fase estacionária, sob a ação gama e elétrons, escala

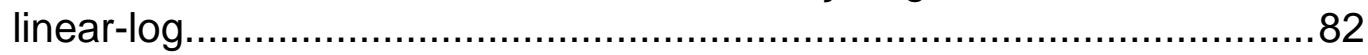

Figura 36: Curvas de sobrevivência de $E$. coli nas fases exponencial e estacionária sob ação combinada de elétrons. Inserção: Curvas de sobrevivência da E. coli nas fases exponencial e estacionária, sob a ação de elétrons, escala linear-log.

Figura 37: Distribuição de fragmentos de DNA por AFS a uma dose de 7kGy. .......86

Figura 38: Distribuição de fragmentos de DNA por AFS a uma dose de 8kGy. .......86 


\section{LISTA DE TABELAS}

Tabela 1 - Espécies de Bactérias resistentes à radiação ionizante.

Tabela 2 - Quebras de dupla fita induzidas em E. coli e D. radiodurans. 36

Tabela 3 - Condições de cultivo de linhagens bacterianas. 44

Tabela 4 - Experimentos e condições de cada irradiação. 49

Tabela 5 - Características da centrífuga .50

Tabela 6 - Características dos tubos de $2 \mathrm{ml}$. .50

Tabela 7 - Características da GammaCell. .53

Tabela 8 - Características do Linac. 57

Tabela 9 - Características Dos feixes de elétrons. 57

Tabela 10 - Características das amostras para o Linac. .58

Tabela 11 - Limites das fases exponencial e estacionária. .62

Tabela 12 - Taxa entre as duas curvas de sobrevivência (figura 24 - inserção). .....69

Tabela 13 - Taxa entre as duas curvas de sobrevivência (figura 31 - inserção). .....78 


\section{LISTA DE SIGLAS E ABREVIATURAS}

AFS - Atomic Force Spectrometry

AmBe - Amerício Berílio

ATCC - American Type Culture Collection

BNCT - Boron neutron capture therapy

CE - campo elétrico

CEE - campo elétrico estático

$\mathrm{CM}$ - campo magnético

DNA - ácido desoxirribonucléico

$\mathrm{DO}_{600}$ - densidade ótica em $600 \mathrm{~nm}$

DSB - double-strand breaks - quebra dupla de DNA

FEB - frequência extremamente baixa

LET - transferência linear de energia

$\mathrm{RI}$ - radiação ionizante

$\mathrm{RT}$ - radioterapia

SSB - single strand breaks - quebra simples de DNA

UFC - unidades formadoras de colônias

UV - ultravioleta 


\section{GLOSSÁRIO DE UNIDADES}

$\mu \mathrm{l}-$ microlitro

g-grama

Gy - unidade de dose de radiação - gray

$\mathrm{Kb}$ - quilobase

$\mathrm{Kpb}$ - quilo pares de base

kGy - unidade de dose de radiação - quilogray

$\mathrm{ml}$ - milititro

mm - milímetro

$\mathrm{Mpb}$ - mega pares de base

$\mathrm{mT}$ - micro tesla

nm - nanômetro

$\mathrm{pb}$ - pares de base

rpm - rotações por minuto

T - Tesla 


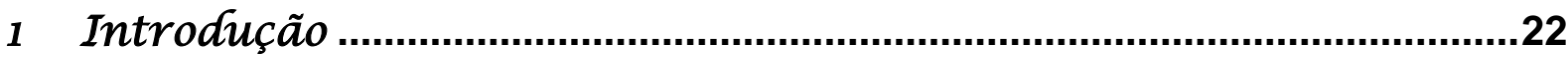

1.1 Radiações lonizantes: Efeitos Biológicos Extra e Intra Celular .....................23

1.2 Radioterapia: Bases Atuais e Necessidades Futuras....................................24

1.3 Efeitos Biológicos Intracelulares de Campos Elétricos e Magnéticos ........27

1.4 Efeito Combinado de Radiação com Campo Elétrico Estático.

1.5 Simulações Radioterápicas com Bactérias - D. radiodurans: Porque Bactérias como Modelo Biológico? .33

1.6 D. radiodurans: Características e Peculiaridades ........................................34

1.7 Motivação para um Estudo da Resposta de D. radiodurans à Ação Combinada de Vários Agentes Físicos Estressantes ..........................................39

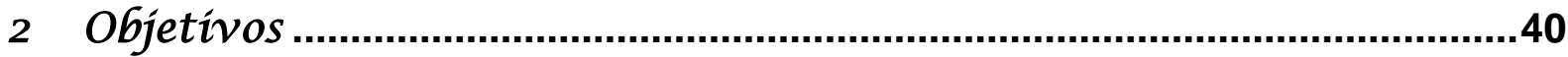

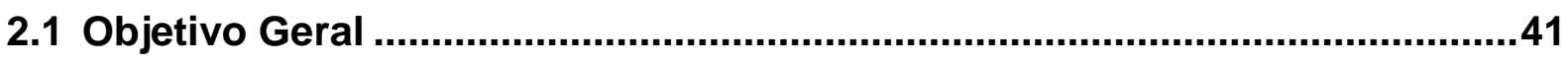

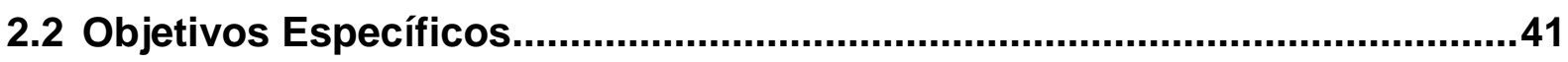

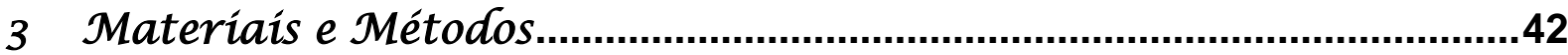

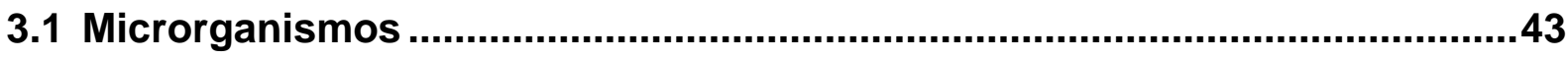

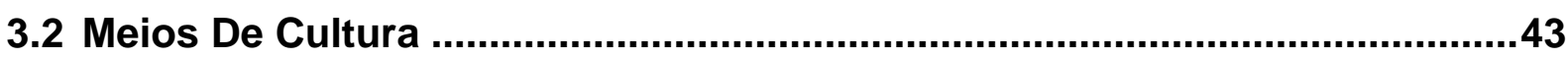

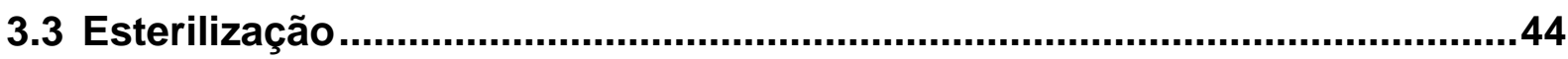

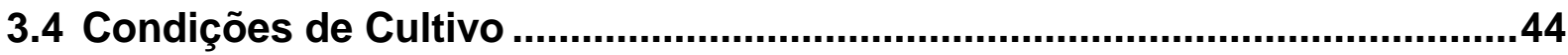

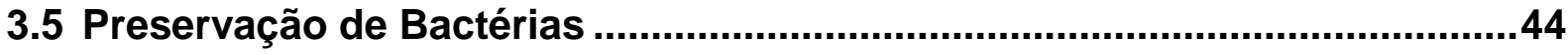

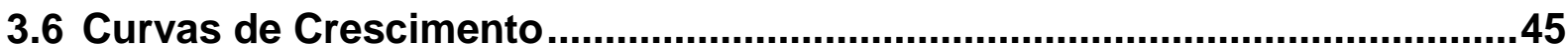

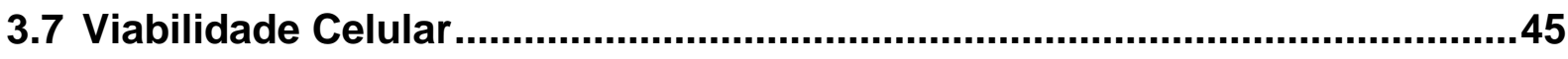

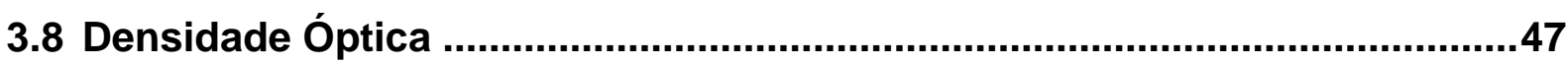

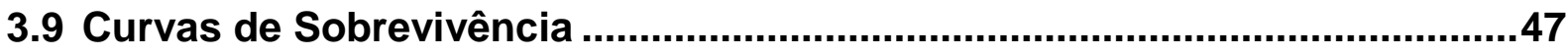

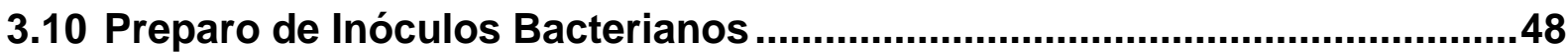

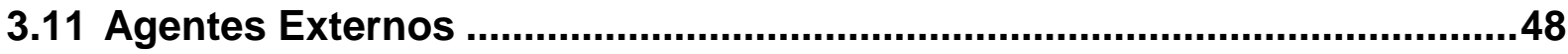

3.12 Preparo para Irradiação com Gamas ......................................................49

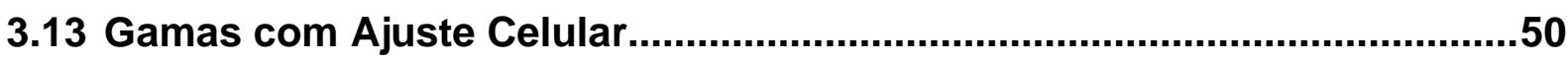

3.14 Características Técnicas da Fonte de Radiação Gama ..............................51

3.15 Gama Combinada com Campos Elétrico e Magnético ..............................53

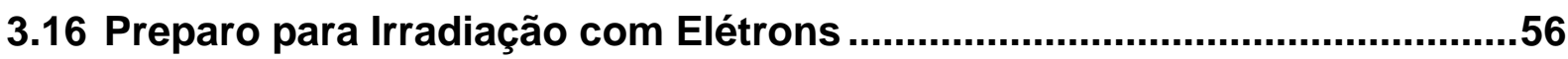

3.17 Características do Acelerador Linear ........................................................56 


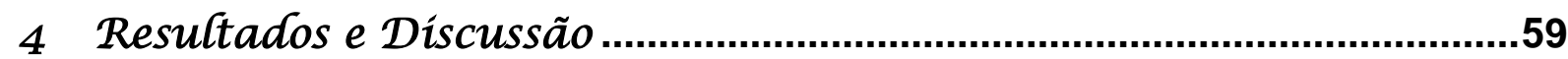

4.1 Irradiações com Gamas e Exposição a Campos Elétricos e Magnéticos....60

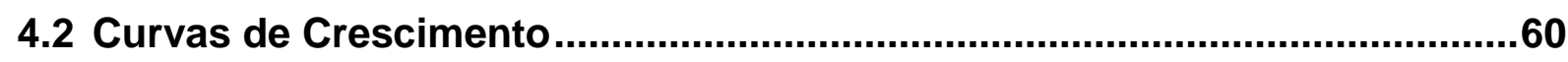

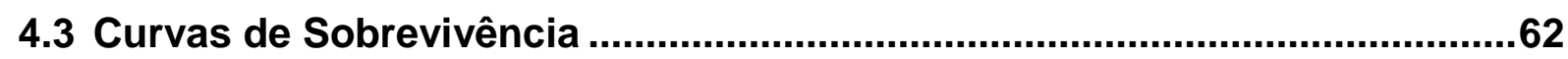

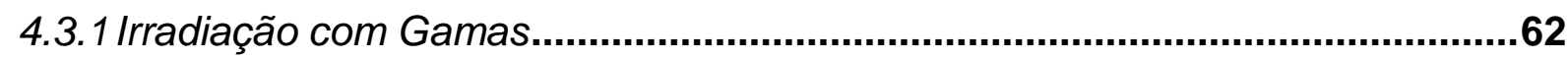

4.3.2 Irradiação com Gamas e Exposição ao Campo Elétrico....................................67

4.3.2.1Proposição de um modelo Biofísico para $\gamma$ + CEE $\quad 72$

4.3.3 Irradiação com Gamas e Exposição ao Campo Magnético ................................75

4.3.3.1Proposição de um modelo Biofísico para $\gamma+\mathrm{CM} \quad \mathbf{7 8}$

4.3.4 Irradiações com Feixes de Elétrons..................................................................79

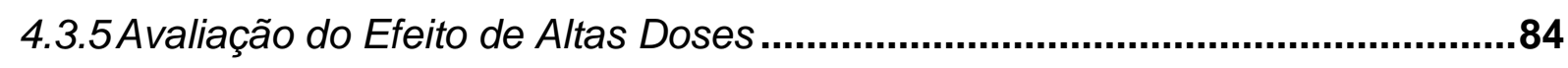

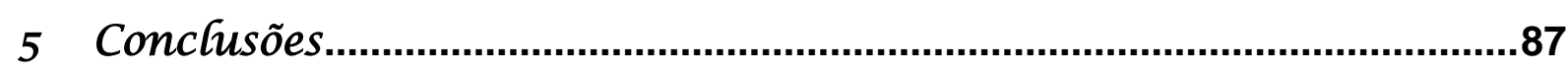

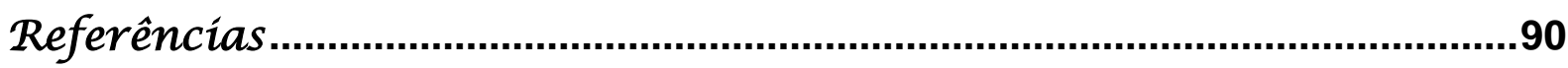

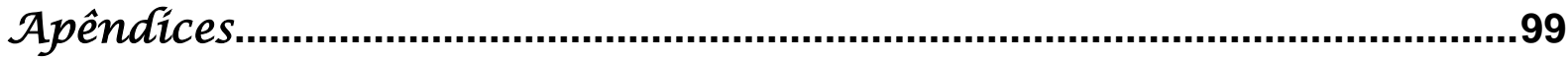

APÊNDICE A - Tabelas de Dados das Figuras..............................................100 


\section{Introdução}




\subsection{Radiações lonizantes: Efeitos Biológicos Extra e Intra Celular}

A radiação ionizante $(\mathrm{Rl})$ é a radiação com energia suficiente para ionizar moléculas. Existem dois tipos de radiação ionizante, ambos produzidos pelo decaimento de elementos radioativos: eletromagnética ( $\mathrm{X}$ e radiação gama, que fazem parte do espectro eletromagnético que inclui a luz visível e ondas de rádio) e de partículas (partículas $\alpha$ e $\beta$ ) (OKUNO, 2006).

A energia depositada (a dose absorvida pela célula ou tecido) é medida em Gray. A radioresistência ou radiossensibilidade de microrganismos é comparada pela da medição da $D_{37}$ (a dose em que $37 \%$ das células sobrevivem). Os íons e radicais livres produzidos com a radiação, passam através da matéria de forma rápida e modificam moléculas. De todos os efeitos dos danos, o genoma tem provavelmente o maior impacto sobre a viabilidade celular. As razões para isso são três. Primeiro, o DNA genômico ocupa a maior fração do volume da célula. Segundo, o genoma está presente em menor número de cópias que outras moléculas. Terceiro, e mais importante, a genoma regula todas as funções celulares, assim a perda de qualquer parcela é catastrófica para um organismo unicelular. A radiação ionizante gera vários tipos de danos ao DNA, como a maior parte do dano resultou da ação de radicais hidroxilas, o espectro de danos é semelhante aos produzidos por danos oxidativos associados ao metabolismo aeróbio (BATTISTA, 2005).

A maioria das lesões é reparada por sistemas de reparo do DNA presente em todas as células, mas as duplas quebras são mais difíceis de reparar e, portanto, o dano é mais letal. As quebras duplas podem resultar em significativa perda de informação genética e, se não forem reparadas, serão impedidas de realizar a replicação do genoma procariótico (MILIAN, 2006).

Desde o descobrimento das RI, há mais de um século, os campos de estudo e aplicações das mesmas têm se desenvolvido enormemente, como é o caso da Radiobiologia. Uma vez conhecida à alta capacidade de penetração da radiação de baixo poder de ionização, esta começou a ser amplamente utilizada nos diagnósticos médicos. Por outro lado, por causa do efeito deletério 
que altas doses podem causar sobre os tecidos vivos, as radiações são também utilizadas na Radioterapia e na Medicina Nuclear para tratamento de tumores. Nestes tratamentos, a radiação interage com o tumor, destruindo as células malignas ou impedindo que cresçam e se reproduzam, mas esta ação pode ser exercida também sobre os tecidos sadios afetados durante 0 tratamento. É interessante notar que tecidos tumorais são mais sensíveis à radiação, já que estes não conseguem reparar os danos produzidos de forma tão eficiente quanto os tecidos normais de forma que terminam sendo destruídos e as células têm seu ciclo replicativo bloqueado (MILIAN, 2006).

A figura 1 mostra as faixas de três diferentes tipos de radiações ionizantes. Os pontos pequenos indicam eventos de deposição de energia (BATTISTA, 2005).

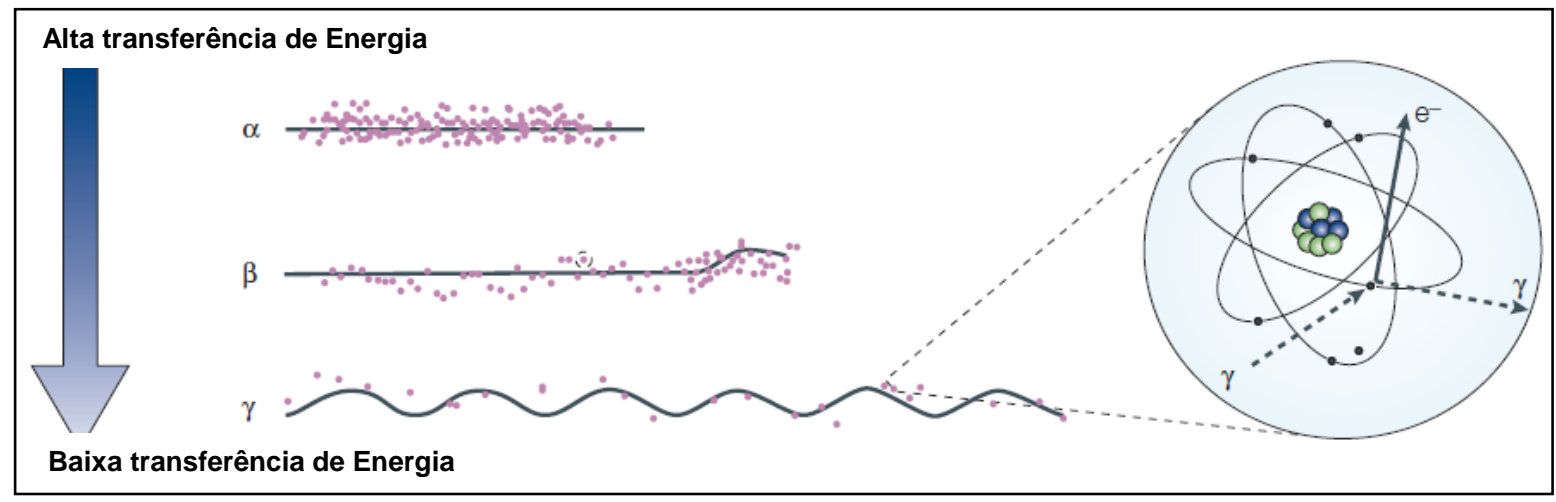

Figura 1: Faixas das radiações $\alpha, \beta$ e $\gamma$.

Fonte: Battista, 1997.

\subsection{Radioterapia: Bases Atuais e Necessidades Futuras}

Segundo recente relatório da Agência Internacional para Pesquisa em Câncer (IARC)/OMS (WORLD CANCER REPORT, 2008), o impacto global do câncer mais que dobrou em 30 anos. O contínuo crescimento populacional, bem como seu envelhecimento, afetará de forma significativa o impacto do 
câncer no mundo. Esse impacto recairá principalmente sobre os países de médio e baixo desenvolvimento. No Brasil, as estimativas do Ministério da Saúde, para o ano de 2010, serão válidas também para o ano de 2011, e apontam para a ocorrência de aproximadamente 500.000 novos casos de câncer. Em 2010, são esperados mais de 230.000 casos novos para o sexo masculino e mais de 250.000 para sexo feminino. Estima-se que o câncer de pele do tipo não melanoma (114 mil casos novos) será o mais incidente na população brasileira, seguido pelos tumores de próstata (52 mil), mama feminina (49 mil), cólon e reto (28 mil), pulmão (28 mil), estômago (21 mil) e colo do útero (18 mil).

Entre as diversas modalidades terapêuticas possíveis, a Radioterapia (RT) é utilizada para uma grande variedade de tumores locais e/ou metastáticos com finalidade curativa ou paliativa. Aproximadamente $50-70 \%$ de todos os pacientes com câncer recebem RT durante $O$ tratamento (MAHRHOFER et al., 2006). Comumente, a RT é prescrita em combinação com cirurgia e/ou quimioterapia, pois estudos demonstraram que estas associações melhoram o controle local do tumor e erradicam micrometástases (KUFE et al., 2003).

Para a realização da radioterapia, os pacientes são submetidos previamente ao planejamento atualmente computadorizado e em três dimensões (3D). A radiação é administrada com o feixe de fótons colimado, isto é, dirigido diretamente para o tumor a ser irradiado, enquanto que o tecido normal recebe a menor dose possível além de proteção de chumbo (NAIR et al., 2001).

As bases da radioterapia moderna se fundamentam no fracionamento e protração da dose, ou seja, são administradas frações de doses diárias ao longo de um tempo. $O$ fracionamento permite que as células nas fases mais sensíveis do ciclo celular (G2/M) sejam destruídas. Posteriormente as células se redistribuem pelo ciclo celular. $\mathrm{Na}$ fração seguinte outras quantidades de células que se encontra nas fases mais sensíveis do ciclo morrem e assim sucessivamente ao longo do tratamento (GELDOF et al., 2003). Entre as frações ocorre o reparo da lesão sub-letal. Neste caso, as células do tecido normal apresentam vantagem quanto ao reparo em comparação às tumorais, pois são mais bem organizadas, quanto ao controle do ciclo celular e contêm 
maior quantidade de enzimas anti-oxidantes como peroxidases e catalases. 0 reparo geralmente ocorre entre 15 minutos a 4 horas após a irradiação.

Outro fator importante é a reoxigenação entre as frações. Estima-se que os tumores humanos têm cerca de $30 \%$ de células hipóxicas e a reoxigenação ocorre em 24 horas. O tempo total do tratamento também é importante, pois as células tumorais podem se dividir e repopular o tumor (FARIA et al., 1994; WITHERS e McBRIDE, 1997).

Considerando-se os aspectos físicos, as radiações ionizantes podem ser classificadas como diretamente ou indiretamente ionizantes. As radiações diretamente ionizantes são as que possuem carga como elétrons, prótons, partículas a e $\beta$ (radiação corpuscular) e as indiretamente ionizantes aquelas que não possuem carga, como UV, raios-X e radiação gama (radiação eletromagnética) e nêutrons. As radiações mais utilizadas na radioterapia são as eletromagnéticas (raios-X e gamas), que produzem efeito biológico ejetando elétrons do meio com o qual interagem. Quando o elétron ejetado promove a lesão celular, é o chamado efeito direto, que corresponde a $30 \%$ do efeito biológico das radiações. O elétron ejetado presente no meio também pode interagir com a água (radiólise da água) produzindo radicais livres e estes promovem a lesão celular. É o efeito indireto e corresponde a $70 \%$ do efeito biológico das radiações (NIKJOO et al., 1994). Como conseqüência da interação com as radiações, as células podem apresentar uma variedade de lesões no DNA (ácido desoxirribonucléico), como bases e açúcares danificados, quebras simples (single-strand breaks - SSB), quebras duplas (double-strand breaks - DSB) e translocações (BELLI et al., 2002; HILL et al., 2004). Biologicamente, entre as alterações radioinduzidas, as quebras duplas do DNA são as mais prejudiciais, podendo promover quebras e rearranjos cromossômicos, deleções, translocações, inversões (mutações estáveis) entre outras lesões que afetam a integridade genômica da célula (MAHRHOFER et al., 2006). A radiação também interage com os lipídios e as proteínas das vias sinalizadoras, além de modular a expressão de genes através de uma variedade de mecanismos incluindo a ativação de fatores de transcrição (McBRIDE e WITHERS, 2004). A ativação radioinduzida destas vias sinalizadoras pode afetar processos como regulação do ciclo celular, reparo do 
DNA, indução da proliferação e repopulação tecidual, diferenciação ou apoptose.

Atualmente há um considerável interesse em desenvolver estratégias que otimize a radioterapia de forma a aumentar a morte de células tumorais e preservar ao máximo o tecido normal adjacente (LI et al., 2005; NAIR et al., 2001; RAMSAY e BIRRELL, 1995). Entre as novas possibilidades de adjuvância terapêutica estudadas, encontra-se a utilização de agentes físicos exógenos como os campos elétricos e magnéticos (AHBOM et al., 2000; GREENLAND et al., 2000; KOYAMA et al., 2005; WERTHEIMER e LEEPER, 1979). Estes constantes estudos também permitem aprimorar técnicas amplamente utilizadas em diversas áreas médicas.

\subsection{Efeitos Biológicos Intracelulares de Campos Elétricos e Magnéticos}

Campo elétrico é o campo de força provocado por cargas elétricas ou por um sistema de cargas, que estão sujeitas a uma força elétrica. Uma característica fundamental de campos elétricos é que em qualquer ponto do espaço, eles têm uma orientação definida correspondente ao sentido da força que eles exercem sobre elementos polares.

Atualmente há poucos trabalhos sobre os efeitos biológicos do campo elétrico estático (CEE) em sistemas vivos. Mesmo assim são controversos e não demonstram sua ação combinada com agentes danificadores de DNA. Kermanshahi e Sailani (2005) demonstraram o efeito do tratamento com campo elétrico estático em dois importantes patógenos, sugerindo que o CEE sozinho é capaz de inibir o crescimento de Escherichia coli e Staphylococcus aureus. Entretanto, este estudo não relata quais os mecanismos de ação deste campo exógeno.

Em Kirson et al. (2004), experimentos realizados com campos elétricos de baixa intensidade e frequência intermediária inibiu o crescimento e a proliferação de células cancerosas, enquanto que, as células e tecidos não cancerosos não foram afetados. Entretanto, para diferentes tipos de células 
cancerosas, há necessidade de aplicação de campos elétricos de intensidades e frequências específicas.

Muitas moléculas, como as de água e de proteínas formam dipolos elétricos em seus estados naturais (sem campo). Dessa forma, ao colocar-se, por exemplo, uma proteína de reparo sob ação desse campo externo não há força resultante, mas há um torque que tende a girar a proteína de modo que o dipolo se alinhe com o campo (Figura 2) (ARRUDA et al., 2010).

Campos elétricos estáticos intensos podem causar trocas nos canais da membrana, conformação de enzimas ou membranas, alterações na forma das proteínas receptoras e de células, ou a neutralização ao redor de células individuais. A intensidade da força produzida pelo campo elétrico é essencial para determinar se a configuração das proteínas ou estruturas celulares será alterada (REPACHOLI e GREENEBAUM, 1999). 


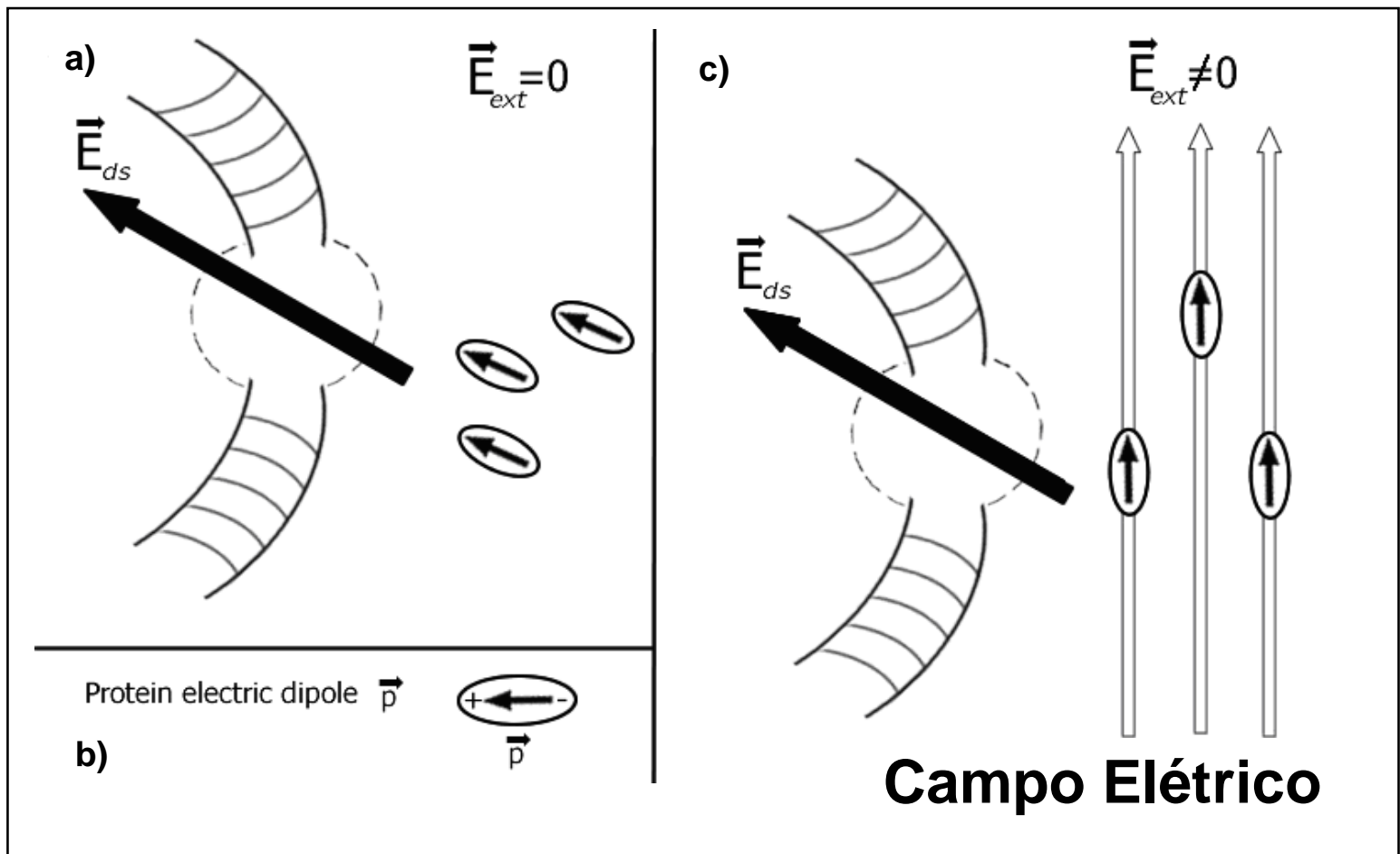

Figura 2: (a) Representação pictórica do processo de reconhecimento de um DSB por proteínas de reparo. Usualmente essas proteínas possuem grandes momentos de dipolo $\vec{p}$ (representado em $b$ com mais detalhes), que se orientam na direção do sítio danificado pela ação de um campo elétrico estático e endógeno $\left(\vec{E}_{d s}\right)$, campo esse produzido pelo desbalanço de cargas elétricas na dupla fita danificada. (c) Um campo elétrico externo $\left(\vec{E}_{e x t}\right)$ mais intenso do que $\left(\vec{E}_{d s}\right)$ reorientaria o deslocamento das proteínas de reparo ao longo de sua direção impedindo, assim, a consecução do reparo.

Fonte: Arruda-Neto et al., 2009.

Em relação ao campo magnético (CM), este é produzido por um ímã ou por cargas elétricas em movimento. Quando uma carga elétrica em movimento está sob ação exclusiva de um $\mathrm{CM}$ ela descreve um movimento circular uniforme.

Segundo Repacholi e Greenebaum (1999) os campos magnéticos estáticos exercem forças sobre íons em movimento em soluções, originando a indução de campos elétricos e correntes (indução magnética). Os CM uniformes produzem torques sob certas moléculas e em alguns materiais ferromagnéticos (efeito magneto-mecânico). Ou mesmo, os CM podem alterar os níveis energéticos e a orientação da rotação dos elétrons (interações eletrônicas). A figura 3 ilustra a ação de um CM agindo sob as proteínas de reparo. 


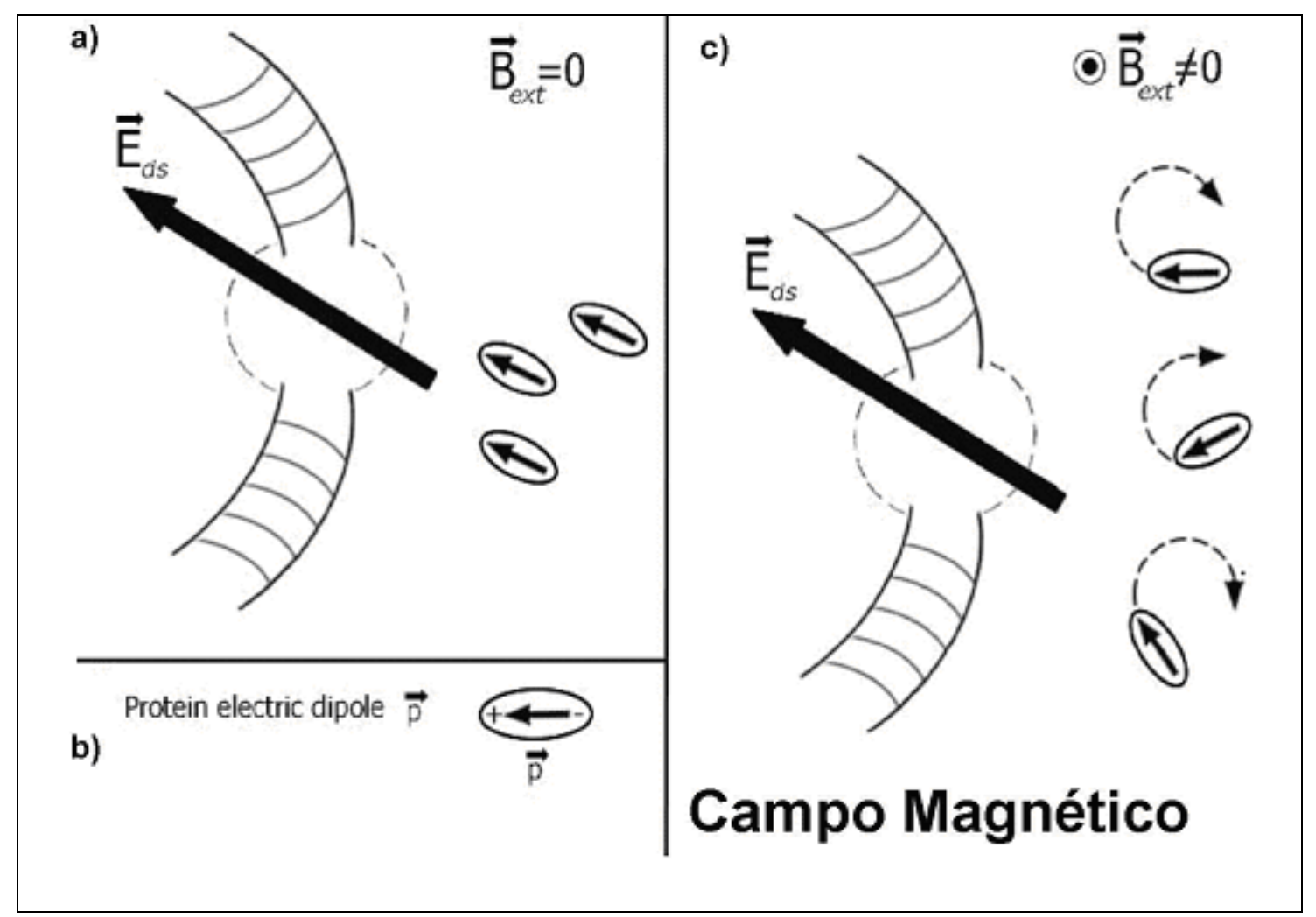

Figura 3: Esquema de ação do campo magnético em cargas em movimento: Efeito inibidor do deslocamento de moléculas dipolares provocado pela ação de um campo magnético. A - Proteínas que apresentam seus momentos de dipolo $\vec{p}$ (representado em B com mais detalhes) orientados na direção do sítio danificado (dupla-quebra) pelo campo elétrico $\overrightarrow{E_{d g}}$. C - Um campo magnético externo $\left(\mathrm{B}_{\text {ext }}\right)$ induz um binário de forças nas proteínas que se deslocam em direção ao sítio danificado, fazendo-as girar centradas em uma mesma posição.

Fonte: Arruda-Neto et al., 2009 e Hobbie et al., 1997.

Koyama et al. (2005) demonstraram que devido à exposição a $5 \mathrm{mT}$ de $\mathrm{CM}$ de frequência extremamente baixa (FEB) imediatamente após irradiação com raio-X ocorreu aumento do número de mutações em plasmídeos de Escherichia coli. Takashima et al. (2003) sugerem que o bloqueio em G1 induzido por doses de radiação ultravioleta (UV) seja inibido pela exposição de Saccharomyces cerevisiae a um campo magnético com FEB de $30 \mathrm{mT}$, em células proficientes e deficientes em reparo. Outros trabalhos investigaram os efeitos de um campo eletromagnético terapêutico (15 mT de amplitude, 120 pulsos/seg), sozinho e em combinação com outros tipos de radiação, como por exemplo a radiação gama utilizada em RT. Os experimentos foram realizados 
in vivo em camundongos nude xenoimplantados com células MDA-MB231linhagem celular humana de câncer de mama (CAMERON et al., 2005). A terapia com radiação associada à exposição ao campo eletromagnético suprimiu o crescimento dos vasos sanguíneos e a repopulação do tumor após a radiação, resultando em uma menor incidência de metástase tumoral. Diversos outros estudos apontam que vários agentes genotóxicos, como raios gama (WALLECZEK et al., 1999) e raios-X (MIYAKOSHI et al., 2000) entre outros, tiveram seu efeito melhorado pela exposição a CM de FEB. Estes resultados sugerem que há chances do $\mathrm{CM}$ de FEB dificultar o processo de reparo do DNA (TAKASHIMA et al., 2003).

\subsection{Efeito Combinado de Radiação com Campo Elétrico Estático}

Segundo um modelo biofísico proposto por nosso grupo de pesquisa (ARRUDA-NETO et al., 2010), a aplicação de um CEE à cultura de células irradiadas deveria interferir negativamente no mecanismo de reparo. Neste caso, um campo externo tenderia a alinhar as proteínas ao longo de sua direção impedindo-as de alcançar o sítio danificado. Essas enzimas de reparo localizam pares de base danificados, num universo de 2 a 3 bilhões de pares de base, por orientação elétrica. Estudos sobre a viabilidade das células procarióticas e eucarióticas simultaneamente expostas à radiação ionizante e de campo elétrico estático têm gerado resultados interessantes e intrigantes. Este estudo foi realizado com o procarioto Microcystis panniformis - uma cianobactéria resistente à radiação e ao calor, com o eucarioto Cândida albicans (fungo) e com células humanas (ARRUDA et al., 2009).

Num estudo com procarioto, Microcystis panniformis, Silva (2006) associou a radiação gama ( $3 \mathrm{kGy}$ ) com um campo elétrico estático de baixa intensidade $(20 \mathrm{~V} / \mathrm{cm})$ por $2 \mathrm{~h}$. Os dados evidenciaram que o efeito combinado da radiação com o agente físico utilizado aumentou 12 vezes a taxa de morte celular em relação às amostras que foram apenas irradiadas. No caso do fungo, Cândida albicans, Louvison (2007) irradiou as células com raios gama 
em doses de 1-4 kGy e submeteu-as a um campo elétrico estático de $180 \mathrm{~V} / \mathrm{cm}$ por $1 \mathrm{~h}$ e $30 \mathrm{~min}$. Os resultados revelaram eliminação do ombro de reparo na curva de sobrevivência das células de $C$. albicans expostas à radiação e a campo elétrico. Estes dois conjuntos de dados puderam evidenciar que 0 campo elétrico estático aumentou a radiossensibilidade destes dois microrganismos. Em células humanas, a citotoxicidade do CEE associado à radiação gamas é da ordem de $12 \%$, de acordo com medidas de viabilidade e foi constatado que a exposição ao CEE por $1 \mathrm{~h}$ com doses de 2 Gy altera a quantidade de histonas H2AX fosforiladas na linhagem normal MRC5, interferindo assim, no processo de reparo das DSBs (figura 4). A análise e interpretação do ciclo celular também indicou que o CEE interferiu no processo de reparo do DNA, notadamente pelo maior acúmulo de células observado na fase $S$ (MORON, 2008).

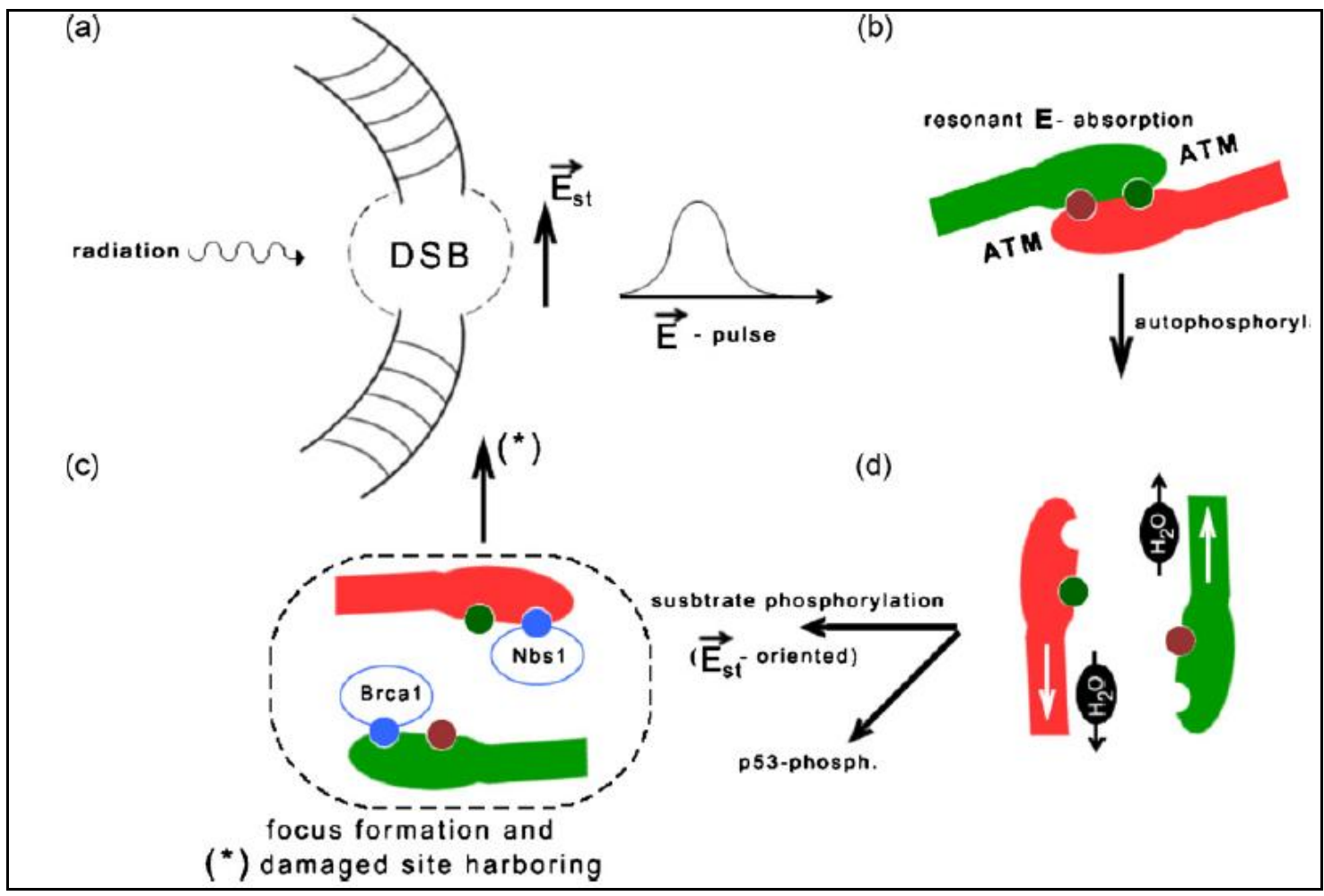

Figura 4: Representação pictória do desdobramento da ATM (b e c) acionado por um pulso elétrico gerando DSB (a), e danos causados pelo campo elétrico - local danificado e proteínas-alvo (c, d).

Fonte: Arruda-Neto, 2010. 
Nestes estudos, ficou comprovado que o campo elétrico aplicado isoladamente não é citotóxico, porém a combinação dos agentes físicos - radiação ionizante e campo elétrico estático - aumenta a morte celular (SILVA, 2006; LOUVISON, 2007; MORON, 2008). Assim realizamos experimentos combinando radiação ionizante e campo elétrico estático.

\subsection{Simulações Radioterápicas com Bactérias - D. radiodurans: Porque Bactérias como Modelo Biológico?}

A sensibilidade dos órgãos do corpo humano está relacionada ao tipo de células que os compõem. A taxa de reprodução das células que formam um órgão não é o único critério para determinar a sensibilidade geral. A importância relativa do órgão para o bem estar do corpo também é importante. A camada externa de células se reproduz rapidamente e também tem um bom suprimento de sangue e oxigênio. As células são mais sensíveis quando estão se reproduzindo e a presença de oxigênio aumenta a sensibilidade à radiação. Células com oxigênio insuficiente tendem a ser inativas, tais como as células localizadas no interior do tumor maligno. Quando o tumor é exposto à radiação, a camada externa de células que estão se dividindo é destruída, fazendo com que o tumor diminua de tamanho. Se o tumor receber uma alta dose para destruí-lo completamente, o paciente também poderá morrer. Assim, é aplicada uma dose baixa no tumor a cada dia, possibilitando que o tecido sadio tenha chance de se recuperar de qualquer dano enquanto, gradualmente, diminui o tumor altamente sensível. Em tratamentos 'in vitro' foi constatado que células de tumores malignos são mais sensíveis à radiação do que no corpo humano (MORON, 2008).

Imamura et al. (2002) utilizou céulas de $D$. radiodurans como modelo para estudo de reparo, por ser de fácil manipulação, ao contrário de células humanas ("in vitro"), possuírem crescimento rápido e por serem resistentes a radiação e a tratamento térmico. 


\subsection{D. radiodurans: Características e Peculiaridades}

A bactéria do gênero Deinococcus, Deinococcus radiodurans, é o extremófilo mais conhecido, entre poucos organismos, que podem sobreviver a exposições extremamente elevadas de radiações ionizantes, vácuo, temperatura, dessecação, peróxido de hidrogênio e vários agentes que causam danos ao DNA (ZAHRADKA, 2006). Por exibir uma extraordinária capacidade em resistir aos efeitos letais e mutagênicos de agentes que danificam o DNA, particularmente os efeitos de radiações ionizantes, a $D$. radiodurans tornou-se o organismo radioresistente mais intrigante da literatura (BATTISTA, 1997) e classificado como o mais resistente do mundo. Estes agentes causam quebras ao genoma do seu DNA em centenas de fragmentos, surpreendentemente; esses fragmentos são facilmente reconectados (ZAHRADKA, 2006).

$\mathrm{Na}$ tabela 1, apresentamos uma lista com seis espécies de bactérias que são resistentes a radiação ionizante, seus filos e $D_{10} . A D_{10}$, representada à dose em que $10 \%$ das células sobrevivem a um evento letal, neste caso, radiação ionizante, ou seja, dose necessária a levas a morte de 90\% da população. A família Deinococcaceae é o filo mais conhecido da lista e estimula estudos a mais de cinco décadas (BATTISTA, 2005).

Tabela 1 - Espécies de Bactérias resistentes à radiação ionizante.

\begin{tabular}{lcl}
\hline \multicolumn{1}{c}{ Espécies } & $\mathbf{D}_{10}$ & \multicolumn{1}{c}{ Filo } \\
Methylobacterium radiotolerans & $1000 \mathrm{~Gy}$ & $\alpha$-Proteobactéria \\
Kocuria rósea & $2000 \mathrm{~Gy}$ & Actinobacteria \\
Acinetobacter radioresistens & $2000 \mathrm{~Gy}$ & $\gamma$-Proteobacteria \\
Kineococcus radiotolerans & $2000 \mathrm{~Gy}$ & Actinobacteria \\
Hymenobacter actinosclerus & $2000 \mathrm{~Gy}$ & Actibobacteria \\
Chroococcidiopsis spp. & $4000 \mathrm{~Gy}$ & Cyanobactéria \\
Rubrobacter xylanophilus & $5500 \mathrm{~Gy}$ & Actinobacteria \\
Deinococcus radiodurans $\mathrm{R} 1$ & $10000 \mathrm{~Gy}$ & Deinococcus \\
& &
\end{tabular}

Fonte: Battista, 2005.

A $D$. radiodurans é o organismo mais tolerante a danos ao DNA já identificado. Entretanto, pouco é conhecido sobre a base bioquímica para este 
fenômeno; no entanto, as evidências disponíveis indicam que o reparo eficiente dos danos ao DNA é, em grande parte, responsável pela radioresistência da $D$. radiodurans. Obviamente, uma explicação desta tolerância aos danos de DNA não pode ser desenvolvido unicamente com base nas estratégias de reparo de DNA dos organismos mais radiossensíveis. A capacidade de sobreviver aos danos do DNA sugere que (A) empregam mecanismos de reparo que são fundamentalmente diferentes de outros procariontes, ou que (B) elas têm a capacidade de potencializar a eficácia dos convencionais complementos de proteínas de reparo do DNA (BATTISTA, 1997).

Embora a $D$. radiodurans tenha sido estudada ao longo dos últimos 40 anos, o conhecimento é mínimo sobre as estratégias de sobrevivência empregadas por este organismo em tolerar os danos ao DNA, isto quando comparamos aos diversos estudos com os organismos procarióticos e eucarióticos mais estudados [por exemplo, Escherichia coli (E. coli) e Saccharomyces cerevisiae (S. cerevisiae)]. A ausência de estudos sobre a $D$. radiodurans dificultou o andamento de novos trabalhos; como consequência, poucos laboratórios fizeram esforços para estudá-la, sufocando assim por muito tempo novos estudos. Porém, o interesse em relação a $D$. radiodurans parece estar crescendo, como é exemplificado pelo número de artigos de revisão publicados nos últimos anos e sobre este organismo e sua capacidade de reparação do DNA. Entre 1956 e 1992, apenas um artigo foi publicado sobre a radiobiologia de $D$. radiodurans, de 1992 a 1997, cinco revisões foram publicadas, e desde então este número vem crescendo (BATTISTA, 1997).

A maioria dos estudos realizados com a $D$. radiodurans teve como foco principal a sua tolerância aos danos no DNA induzidos por radiação gama e luz ultravioleta (UV). Todos apontam a $D$. radiodurans como o organismo mais resistente já identificado, sobrevivendo sem perda de sua viabilidade a doses entre 5 e $7 \mathrm{kGy}$, enquanto a $E$. coli, por exemplo, não suporta a doses maiores do que $0,5 \mathrm{kGy}$ para irradiações com gama (BATTISTA, 2005).

A curva de sobrevivência a UV da $D$. radiodurans e $E$. coli são comparadas na figura 5. A E. coli exibe um declive exponencial de viabilidade, enquanto que a $D$. radiodurans tem ombro de resistência que estende a 500 $\mathrm{J} / \mathrm{m}^{2}$. A $D_{37}$ para radiação UV é de aproximadamente $30 \mathrm{~J} / \mathrm{m}^{2}$ para $E$. coli e 
entre 550 e $600 \mathrm{~J} / \mathrm{m}^{2}$ para o crescimento exponencial das culturas de $D$. radiodurans $\mathrm{R} 1$. As doses de radiação UV que a $D$. radiodurans tolera causam uma grande quantidade de danos ao DNA. Para $500 \mathrm{~J} / \mathrm{m}^{2}$, por exemplo, é estimado uma média de 1 lesão para cada 600 pares de base (BATTISTA, 1997).

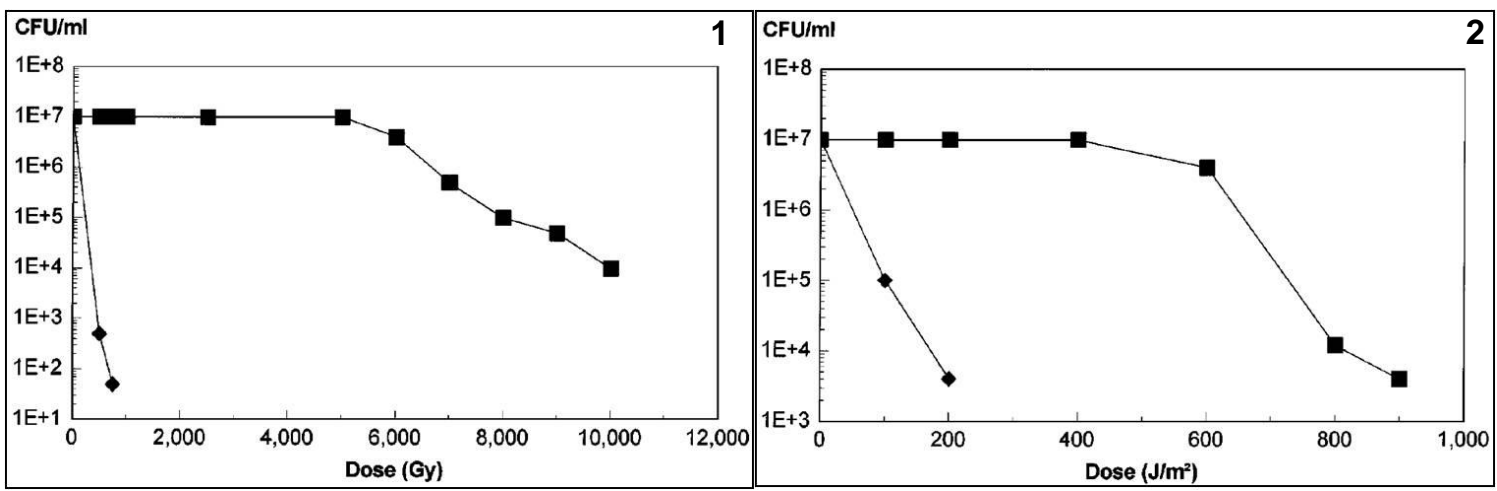

Figura 5: 1- Representação da curva de sobrevivência da $D$. radiodurans (quadrados) e da $E$. coli (diamantes) exposta a radiação gamas. 2 - Representação da curva de sobrevivência da $D$. radiodurans (quadrados) e da $E$. coli (diamantes) exposta a radiação UV.

Fonte: Battista, 1997.

Para doses acima de 7 kGy, a sobrevivência de $D$. radiodurans diminui muito rapidamente. Em termos de danos ao DNA, 6 kGy de irradiação gama pode induzir aproximadamente 200 (DSB) de DNA e acima de 3.000 (SSB), e mais de 1000 locais de danos de bases por genoma da $D$. radiodurans. O tipo selvagem de $D$. radiodurans é também extremamente resistente a radiação UV, sobrevivendo a doses tão elevadas quanto $1000 \mathrm{~J} / \mathrm{m}^{2}$. (BATTISTA, 1997).

A tabela 2 compara o número de quebras duplas no DNA da $E$. coli e $D$. radiodurans $\mathrm{R} 1$ com radiação gama em $\mathrm{D}_{37}$, ou seja, a dose em que apenas 37\% das células sobrevivem (BATTISTA, 2005).

Tabela 2 - Quebras de dupla fita induzidas em E. coli e D. radiodurans.

\begin{tabular}{|c|c|c|c|}
\hline Espécies & élulas por Genoma & $\begin{array}{c}\text { Quebras duplas de } \\
\text { DNA }\left(D_{37}\right)\end{array}$ & $\begin{array}{l}\text { Distância Média } \\
\text { entre lesões }\end{array}$ \\
\hline Escherichia coli K12 & $4-5$ & $8-9$ & $530 \mathrm{kpb}$ \\
\hline Deinococcus radiodurans $\mathrm{R} 1$ & $8-10$ & 275 & $10 \mathrm{kpb}$ \\
\hline
\end{tabular}

Fonte: Battista, 2005. 
A diferença é impressionante; a $D$. radiodurans tolera 30 vezes mais quebras duplas no DNA do que a $E$. coli. Claramente, a $D$. radiodurans possui mecanismos para evitar os efeitos letais das quebras de fitas duplas, ou seja, mecanismos de reparo muito eficientes, produzido por radiação ionizante, o que a $E$. coli não possui.

A maioria das células resistentes às radiações ionizantes é capaz de acumular cerca de 300 vezes mais manganês $(\mathrm{Mn})$ do que as células mais sensíveis às radiações ionizantes (DALY et al., 2004). Os depósitos de manganês estão espalhados em diferentes regiões do planeta. O Programa de Perfuração no Oceano (ODP) é uma organização internacional que tem conduzido centenas de expedições para pesquisa básica sobre a história do assoalho oceânico em diversas partes do mundo. Recentemente, O ODP conduziu um levantamento de uma grande variedade de sedimentos marítimos (D'HONDT et al., 2004). Curiosamente, microrganismos anaeróbios e hipertermofílicos pertencentes ao gênero Deinococcus foram isolados de fontes hidrotermais com profundidades entre $65 \mathrm{~m}$ e $129 \mathrm{~m}$ (abaixo do assoalho oceânico), onde a temperatura varia de $76{ }^{\circ} \mathrm{C}$ a $91^{\circ} \mathrm{C}$ (KIMURA et al., 2003). Estes resultados sugerem que uma espécie ancestral resistente a radiação ionizante, compartilhada por espécies do gênero Deinococcus e outras espécies anaeróbias hipertermofílicas podem ter existido em sítios ricos em Mn, com altos níveis de radiação (PAULINO-LIMA, 2010).

Estudos sobre a $D$. radiodurans revelaram que esse organismo é altamente eficiente no reparo de DNA danificado. $D$. radiodurans dispõe de várias enzimas diferentes de reparo de DNA. Além da enzima de reparo de DNA, RecA, D. radiodurans possui sistemas de DNA independentes de RecA capazes de promover o reparo de rupturas em DNA de fita simples ou dupla, além da excisão e do reparo de bases incorretamente incorporadas. De fato, os processos de reparo são tão eficientes, que o cromossomo pode ser reorganizado até mesmo a partir de um estado fragmentado (MADIGAN, 2004).

Acredita-se também que o arranjo peculiar do DNA nas células de $D$. radiodurans desempenha um papel na resistência à radiação. As células de $D$. radiodurans estão sempre presentes em pares ou tétrades (MADIGAN, 2004). 
Vários são os mecanismos celulares que contribuem para a alta resistência à radiação, podendo ser classificados em (i) mecanismos passivos, como a produção de carotenóides que funcionam como escudo contra as radiações não ionizantes (ultravioleta), e (ii) os mecanismos ativos que incluem a reparação de danos no DNA (GHOSAL et al., 2005). Os mecanismos ativos compreendem pelo menos duas categorias (MAKAROVA et al., 2001; BATTISTA, 2005; MAKAROVA et al., 2007): (i) um subconjunto de genes que codificam proteínas com funções ainda desconhecidas que podem aumentar muito a eficiência dos mecanismos de reparação do DNA, e (ii) complexos de manganês ( $\mathrm{Mn})$ não-enzimáticos presentes em microrganismos radioresistentes que protegem as enzimas contra a oxidação durante a irradiação (DALY et al., 2004), preservando os sistemas de reparação do DNA que acabam funcionando com eficiência muito maior do que em microrganismos radiosensíveis (HE, 2009). Essas duas categorias possuem um denominador comum: a forte correlação positiva entre a resistência à radiação ionizante e a tolerância à dessecação (SGHAIER et al., 2007). Atualmente, a comunidade científica assume que a resistência à radiação é uma conseqüência da adaptação à dessecação (hipótese da adaptação à dessecação), uma vez que o principal tipo de dano celular provocado por estes dois tipos de estresses é o mesmo, ou seja, quebra de fita dupla no DNA (PAULINO-LIMA, 2010).

Essa hipótese afirma que a resistência à radiação ionizante de $D$. radiodurans é uma consequência da sua adaptação à dessecação. No entanto, não há dados genômicos ou experimentais sugerindo que a tolerância à dessecação é antecedente à resistência à radiação ionizante. Resumidamente, os dados apresentados por Mattimore e Battista (1996), apenas sugerem uma forte correlação positiva entre estes dois fenótipos. De fato, um co-autor da hipótese da adaptação à dessecação mostrou que a inativação de DRB0118, uma proteína constitutivamente expressa, sensibiliza $D$. radiodurans à dessecação, mas não à radiação ionizante (BATTISTA et al., 2001). Além disso, a hipótese da adaptação a dessecação (MATTIMORE e BATTISTA, 1996) não explica a resistência extrema à radiação ionizante observada em vários membros do domínio Archaea (KOPYLOV et al., 1993). A hipótese 
alternativa, de que a tolerância de $D$. radiodurans à dessecação pode ser uma conseqüência da adaptação desse organismo à radiação ionizante (hipótese da adaptação à radiação) é também apoiada por várias linhas de evidências, devendo ser investigada com igual teor (SGHAIER et al., 2007).

\subsection{Motivação para um Estudo da Resposta de $D$. radiodurans à Ação Combinada de Vários Agentes Físicos Estressantes}

A Deinococcus radiodurans constitui um modelo biológico viável para o estudo de reparo (IMAMURA, 2002). Este estudo pode ser usado para esclarecer os mecanismos de reparo de diversos organismos a partir deste modelo, além de poder ser amplamente utilizado em oncologia.

Como os tumores in vivo, a $D$. radiodurans é resistente à ação de radiação, mais especificamente a radiação gama (BATTISTA, 2005). Existe consenso quanto à necessidade de minimizar os efeitos ou lesões aos tecidos sadios adjacentes, um objetivo ainda não atingido. Por outro lado, há evidências de que a associação de radiação com outros agentes físicos exógenos, como campos elétricos e magnéticos, aumenta significativamente a radiossensibilidade celular in vitro (ARRUDA-NETO, 2009; ARRUDA-NETO, 2010; SILVA, 2006; LOUVISON, 2007; MORON, 2008). Esses resultados, se verificados in vivo, poderiam servir de base para a elaboração de novos protocolos radioterápicos que empregassem baixos níveis de dose.

Contudo, o estudo de tumores in vivo apresenta inúmeras dificuldades e incertezas, principalmente devido à necessidade de utilização em grande número de animais, esbarrando sempre em entraves impostos pelos Comitês de Ética.

Portanto, estudaremos a viabilidade da bactéria radioresistente Deinococcus radiodurans como modelo de estudo de reparo a ação combinada de radiações ionizantes com campos elétricos e magnéticos. 
2Objetivos 


\subsection{Objetivo Geral}

Estudo detalhado do comportamento da bactéria radioresistente $D$. radiodurans quando exposta a radiações convencionais (gamas), não convencionais (elétrons) e outros estresses exógenos (campos elétricos e magnéticos). Propor, a partir dos resultados obtidos, 0 uso desse microrganismo como modelo bacteriano em oncologia e medicina regenerativa.

\subsection{Objetivos Específicos}

Os objetivos específicos deste estudo são:

1- Delineação das fases de crescimento de Escherichia coli e Deinococcus radiodurans, exponencial e estacionária via medidas de curvas crescimento dessas linhagens bacterianas.

2- Determinar a radioresistência de Deinococcus radiodurans através de curvas de sobrevivência utilizando diferentes tipos de radiações (gamas e elétrons).

3- Determinar a ocorrência ou não de efeitos sinergéticos entre exposição da Deinococcus radiodurans à radiação gama e a aplicação de agentes físicos exógenos (campos elétrico e magnético).

4- Estudar as peculiaridades radiosensíveis nas fases de crescimento exponencial e estacionária da linhagem de $D$. radiodurans por meio de medidas de radiossensibilidade com gamas, com ajuste na suspensão celular. 


\section{Materíaís e Métodos}




\subsection{Microrganismos}

Neste estudo foram utilizadas a cepa selvagem GY 9613 (R1) da bactéria Deinococcus radiodurans (cedida pelo Dr. Carlos Eduardo Bonacossa de Almeida do Instituto de Radioproteção e Dosimetria do Rio de Janeiro/IRDRJ) e a linhagem ATCC 11229 da bactéria Escherichia coli.

\subsection{Meios De Cultura}

Os seguintes meios de cultura foram utilizados neste estudo.

\section{TGY (ANDERSON et al., 1956)}

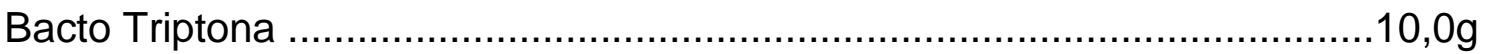

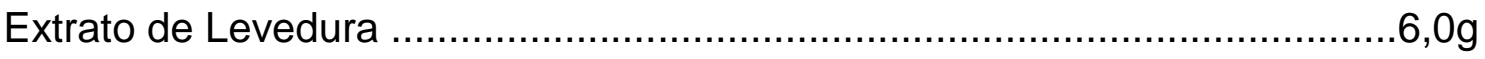

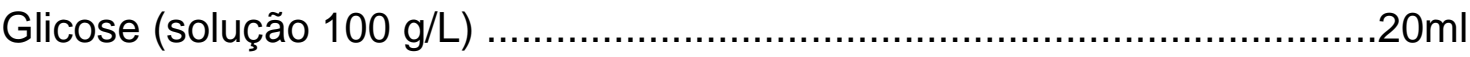

Agar (para meios sólidos) ……….........................................................16g

Água destilada q.s.p. ..............................................................1000ml

\section{LB (MILLER, 1992)}

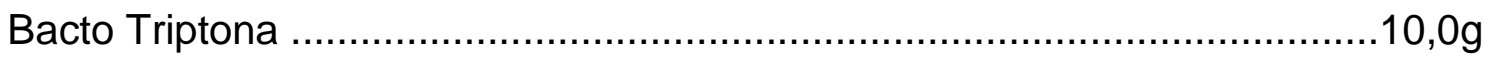

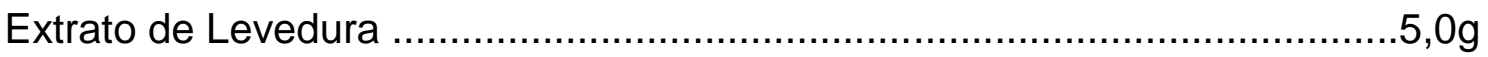

$\mathrm{NaCl}$

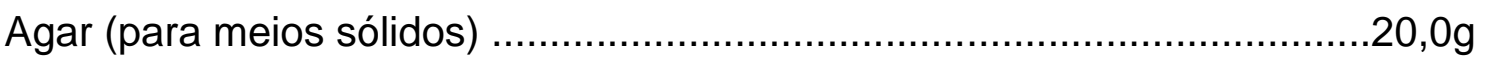


Água destilada q.s.p.

$.1000 \mathrm{ml}$

\subsection{Esterilização}

Materiais e meios de cultura foram esterilizados em autoclave a $121{ }^{\circ} \mathrm{C}$, por 15 minutos.

\subsection{Condições de Cultivo}

As condições de cultivo de cada uma das linhagens bacterianas estão apresentadas na tabela 3 . As culturas foram incubadas em estufa bacteriológica (Fanem, 502) ou agitador rotativo (Tecnal, TE420).

Tabela 3 - Condições de cultivo de linhagens bacterianas.

\begin{tabular}{cccc}
\hline Linhagem bacteriana & $\begin{array}{c}\text { Meio de } \\
\text { cultura }\end{array}$ & $\begin{array}{c}\text { Temperatura } \\
\left({ }^{\circ} \mathbf{C}\right)\end{array}$ & $\begin{array}{c}\text { Agitação } \\
(\mathbf{r p m})\end{array}$ \\
\hline D. radiodurans & TGY & 30 & 200 \\
\hline E. coli & LB & 37 & 200 \\
\hline
\end{tabular}

\subsection{Preservação de Bactérias}

As bactérias acima citadas foram criopreservadas em freezer $-80{ }^{\circ} \mathrm{C}$ suspensas em solução de glicerol. Cada linhagem bacteriana foi incubada em meio sólido segundo suas respectivas características de cultivo (tabela 3) em estufa bacteriológica, por 24 horas. Este cultivo foi utilizado para inocular um novo meio de cultura, sendo então incubado até atingir a fase estacionária. Em seguida, as culturas foram diluídas 1:1 em solução de glicerol a $20 \%(\mathrm{~m} / \mathrm{v})$. A suspensão de células em glicerol foi mantida em congelador $-15{ }^{\circ} \mathrm{C}$ por 1 hora sendo então transferida para freezer $-80^{\circ} \mathrm{C}$. 


\subsection{Curvas de Crescimento}

Para o estabelecimento da curva de crescimento das culturas bacterianas citadas acima, as linhagens criopreservadas (figura 6) foram inoculadas no seu respectivo meio de cultura (TGY e LB) e incubadas por 24 horas em agitador rotativo em suas respectivas condições de cultivo (tabela 3 ). Essa cultura foi utilizada para inocular um novo meio de cultura; este "novo" inóculo correspondeu a 10\% do volume final do novo meio (TGY e LB). A curva de crescimento foi obtida a partir de determinações periódicas (a cada 2 horas) de viabilidade celular (UFC/ml) e densidade ótica a $600 \mathrm{~nm}\left(\mathrm{DO}_{600}\right)$.

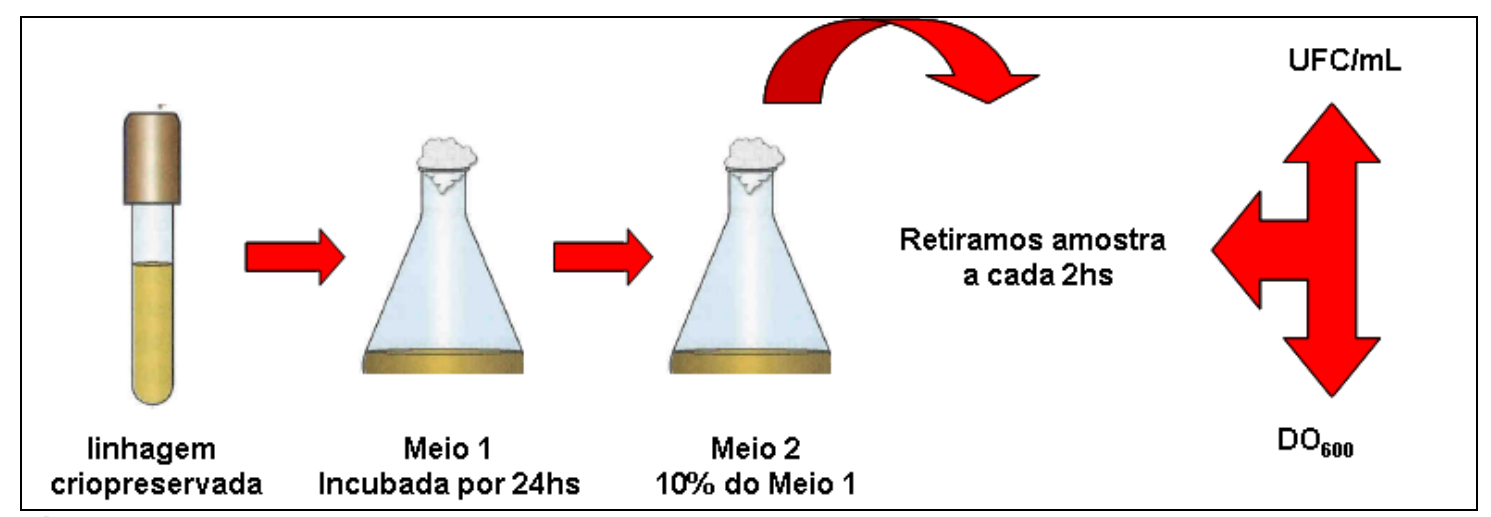

Figura 6: Montagem do experimento para a determinação da curva de crescimento da $D$. radiodurans e E. coli.

\subsection{Viabilidade Celular}

A viabilidade celular foi obtida a partir de diluições decimais em solução salina ( $\mathrm{NaCl} 0,85 \%)$, seguidas da inoculação de $100 \mu \mathrm{l}$ da cultura crescida em placas de Petri contendo o meio de cultura sólido (TGY e LB). As placas foram incubadas em estufa bacteriológica de acordo com as características de cada bactéria (tabela 3). A figura 7 esquematiza este procedimento. 


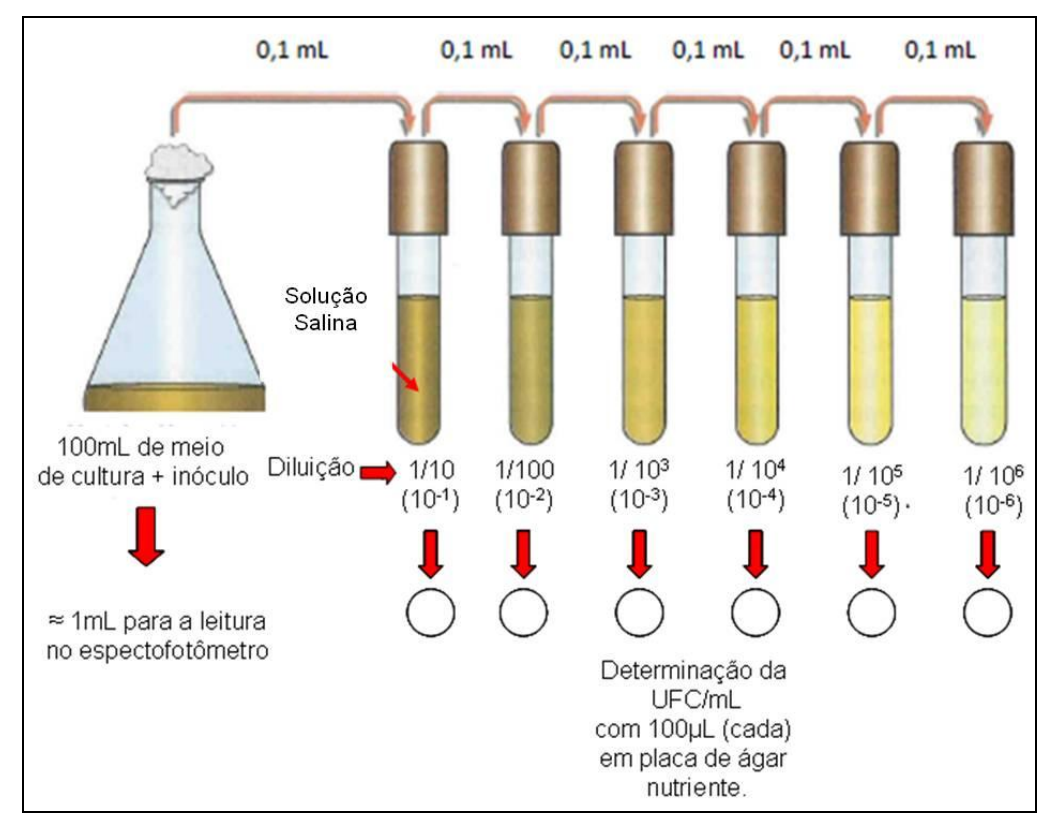

Figura 7: Diluições seriadas.

Após incubação (figura 8), houve a contagem do número de colônias que foi determinada pela média do número de colônias por diluição. A viabilidade celular foi estabelecida pela fórmula a seguir.

Viabilidade Celular $=\underline{\text { Número Médio de Colônias x } 10 \quad(U F C / m I)}$

\section{Diluição}

As determinações foram sempre realizadas em triplicata.

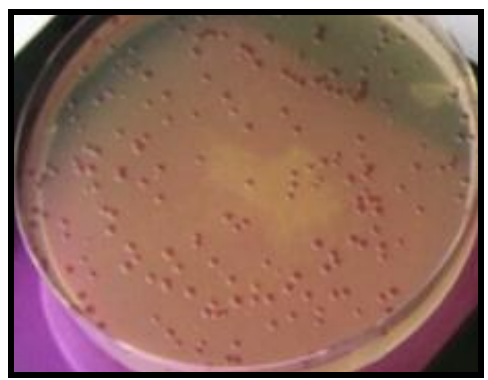

Figura 8: Colônias da D. radiodurans. 


\subsection{Densidade Óptica}

A densidade óptica foi determinada em espectrofotômetro (Varian, 50 Bio) a $600 \mathrm{~nm}\left(\mathrm{DO}_{600}\right)$. Sempre que $\mathrm{DO}_{600}$ se aproximava de 1,0 foi realizada diluição em meio de cultura para que a leitura fosse realizada na faixa de $0,2 \mathrm{e}$ 0,8 unidades de absorbância.

Foram retiradas amostras do meio crescido a cada 2 horas por 24 horas para a leitura da absorbância.

Com os dados de viabilidade celular (UFC/ml) e densidade de absorbância $\left(\mathrm{DO}_{600}\right)$, foi construída a curva de crescimento.

Definida a curva de crescimento, estipulamos a partir da construção do gráfico as fases exponencial e estacionária, das bactérias utilizadas em nosso estudo.

\subsection{Curvas de Sobrevivência}

Para a determinação das curvas de sobrevivência as linhagens celulares de $D$. radiodurans e $E$. coli foram cultivadas conforme descrito anteriormente.

Para irradiações com gamas foram utilizadas amostras líquidas em tubos de $2 \mathrm{ml}$. Após a irradiação, as amostras foram diluídas, plaqueadas e levadas a estufa.

Nas irradiações com elétrons, utilizamos amostras plaqueadas em placas de Petri contendo ágar. Após as irradiações, as amostras foram incubadas em estufa bacteriológica.

Para avaliar a relação entre a dose da radiação e a proporção de células que sobreviveram, calculamos a viabilidade celular (VC), que indica a porcentagem de células plaqueadas que sobreviveram à dose aplicada (equação do item 3.7). 


\subsection{Preparo de Inóculos Bacterianos}

De uma cultura crescida $24 \mathrm{~h}$ foi retirado $10 \%$ em relação ao volume do novo meio de cultura e inoculado até alcançar as fases exponencial e estacionária de cada bactéria. As amostras preparadas para as irradiações seguiram o esquema da figura 9 .

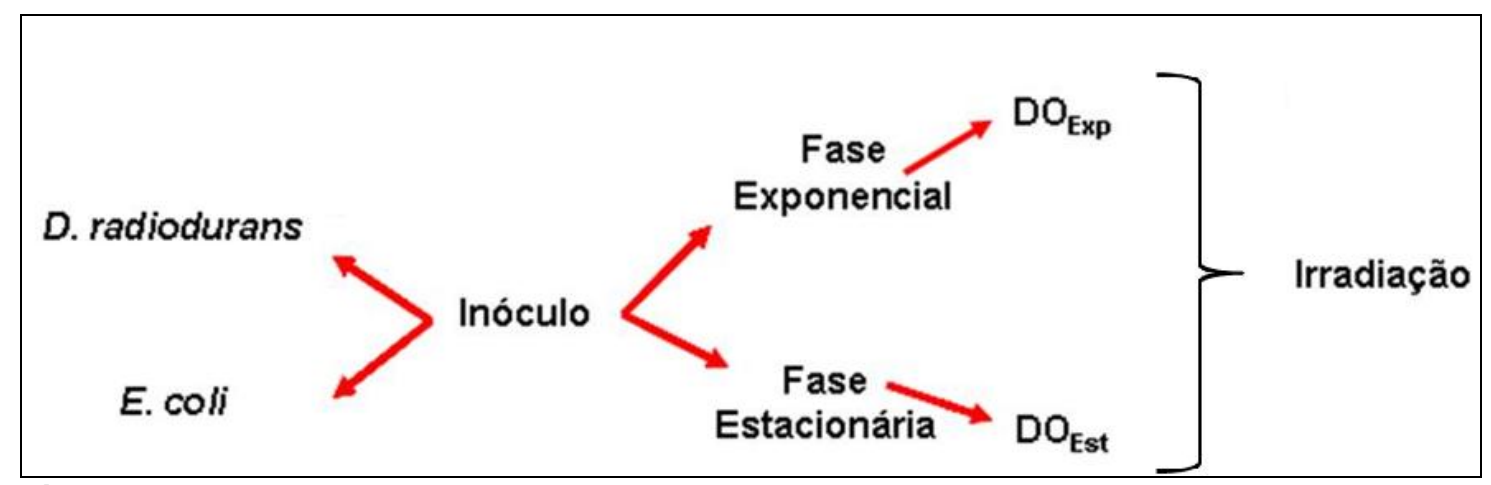

Figura 9: Esquema de preparação das culturas para irradiações.

\subsection{Agentes Externos}

As irradiações foram realizadas nas linhagens de $D$. radiodurans e $E$. coli de acordo com o esquema apresentado na figura 10. 


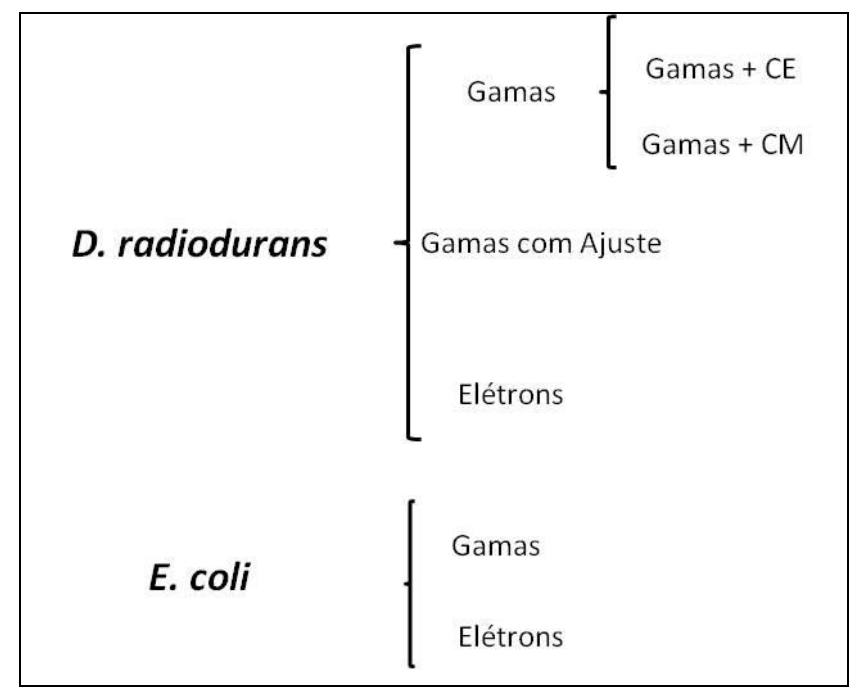

Figura 10: Esquema das irradiações para as linhagens bacterianas em estudo.

Apresentamos de forma detalhada na tabela 4, todos os experimentos realizados com as linhagens bacterianas envolvidas no estudo.

Tabela 4 - Experimentos e condições de cada irradiação.

\begin{tabular}{|c|c|c|c|c|c|}
\hline \multirow{2}{*}{ Agente Externo } & \multicolumn{2}{|c|}{ D. radiodurans } & \multicolumn{2}{|c|}{ E. coli } & \multirow{2}{*}{$\begin{array}{l}\text { Meio de } \\
\text { cultura }\end{array}$} \\
\hline & Faixa & Intervalo & Faixa & Intervalo & \\
\hline Gamas & $1-12$ kGy & $1 \mathrm{kGy}$ & $0,5-4 k G y$ & 0,5 kGy & líquido \\
\hline Gamas + Campo Elétrico (10 h) & 2-8 kGy & 2 kGy & - & - & líquido \\
\hline Gamas + Campo Magnético (10 h) & 2-8 kGy & 2 kGy & - & - & líquido \\
\hline Elétrons & $1-12 \mathrm{kGy}$ & $1 \mathrm{kGy}$ & $0,5-4 k G y$ & $0,5 \mathrm{kGy}$ & sólido \\
\hline Gamas (com ajuste) & $1-12$ kGy & $1 \mathrm{kGy}$ & - & - & líquido \\
\hline
\end{tabular}

\subsection{Preparo para Irradiação com Gamas}

Retirou-se uma amostra de cada cultura em sua respectiva fase de crescimento (fase exponencial e estacionária) para o preparo para a irradiação.

As amostras foram ressuspendidas em tubo de $25 \mathrm{ml}$ em centrífuga (vide tabela 5). Foi desprezado o sobrenadante e as células foram lavadas em solução salina $(0,85 \%)$. 
Tabela 5 - Características da centrífuga.

\begin{tabular}{c|c|c}
\hline Rotações (rpm) & Tempo & Temperatura \\
\hline 8000 & $10 \mathrm{~min}$ & $5^{\circ} \mathrm{C}$ \\
\hline
\end{tabular}

Após a lavagem das células, as amostras (em meio líquido) foram acondicionadas em tubos de $2 \mathrm{ml}$ para serem irradiadas com gamas. As características dos tubos utilizados para as irradiações com gamas e exposição aos campos exógenos são especificadas na tabela 6 .

Tabela 6 - Características dos tubos de $2 \mathrm{ml}$.

\begin{tabular}{c|c}
\hline Formato & cônico \\
\hline Diâmetro externo & $10,5 \mathrm{~mm}$ \\
\hline Diâmetro interno & $9,0 \mathrm{~mm}$ \\
\hline Espessura & $1,0 \mathrm{~mm}$ \\
\hline Altura externa & $39,5 \mathrm{~mm}$ \\
\hline
\end{tabular}

\subsection{Gamas com Ajuste Celular}

Este método de ajuste da concentração celular para as fases exponencial e estacionária foi utilizado apenas para a $D$. radiodurans. $O$ preparo do inóculo bacteriano foi descrito no item 3.10 e na tabela 5 .

Visando obter a mesma concentração celular nas fases exponencial e estacionária $\left(10^{8} \mathrm{cel} / \mathrm{ml}\right)$ foram realizadas leituras em espectrofotômetro e diluições em salina para obter-se uma densidade ótica (DO) aproximada.

Em seguida, as amostras foram resuspendidas em salina (tabela 5), com a mesma concentração celular em um volume final de $25 \mathrm{ml}$. Acondicionadas em tubos de $2 \mathrm{ml}$ as amostras foram levadas para a irradiação com gamas.

Foram realizados dois métodos com gamas:

Método 1 - sem ajuste da concentração celular para as fases exponencial e estacionária (item 3.12). 
Método 2 - com ajuste da concentração celular para as fases exponencial e estacionária (descrito acima, item 3.13).

\subsection{Características Técnicas da Fonte de Radiação Gama}

As amostras em tubos de $2 \mathrm{ml}$ foram irradiadas com gamas em doses que variaram entre 1-12 kGy para $D$. radiodurans e 0,5-4 kGy para a E. coli.

As amostras foram irradiadas no CTR-IPEN, Centro de Tecnologia das Radiações, do Instituto de Pesquisas Energéticas e Nucleares, da Comissão Nacional de Energia Nuclear - CNEN.

O CTR projetou e construiu com tecnologia própria, um irradiador

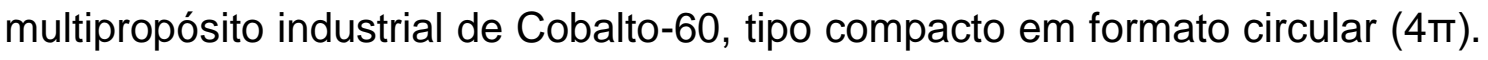
Assim, todas as amostras recebem a mesma dose de forma homogênea (figuras 11 e 12). 


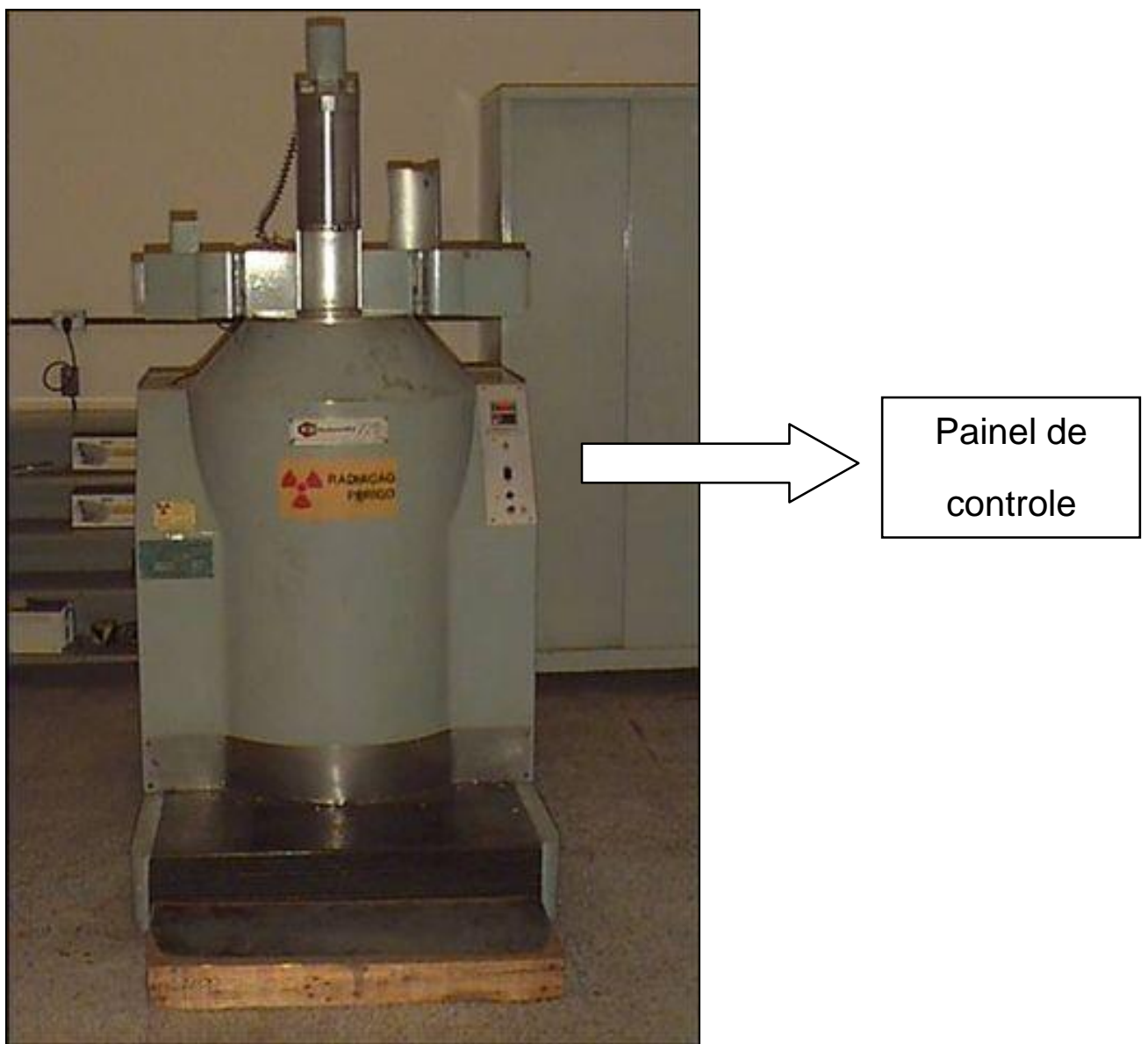

Figura 11: Irradiador Gammacel, em detalhe o painel de controle.

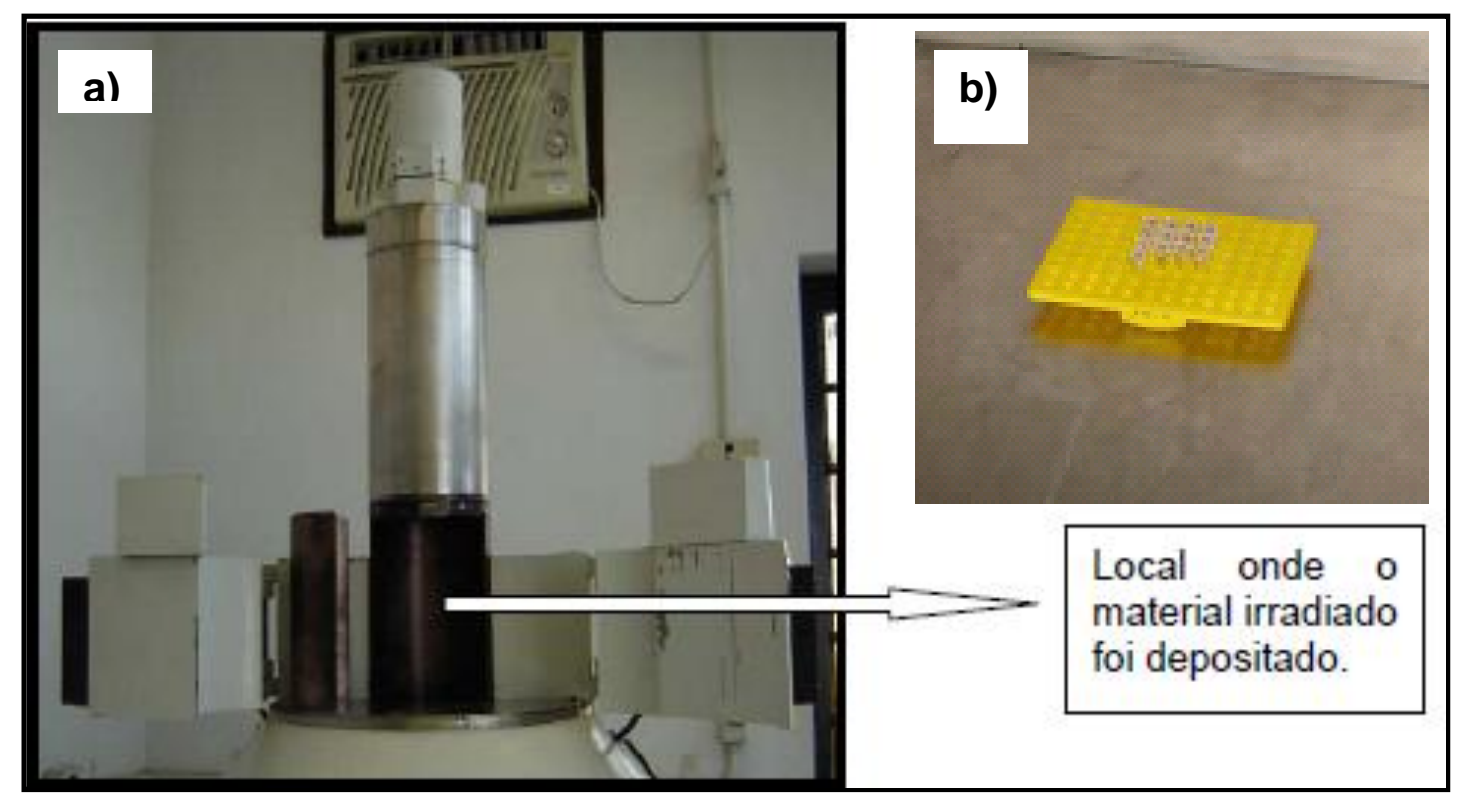

Figura 12: A) Abertura do compartimento em que o material irradiado foi depositado; B) Geometria das amostras no irradiador de $\mathrm{Co}_{60}$. As amostras ficaram num plano horizontal e foram retiradas à medida que acumulavam as doses predefinidas para cada uma. 
Nestas irradiações, utilizou-se o suporte apresentado na figura 12 (lado B), que foi colocado ao centro da fonte de radiação gama.

Após irradiação com gamas, uma parte das amostras contidas em tubos de $2 \mathrm{ml}$ foram plaqueadas para obtenção das curvas de sobrevivência com gamas e as duas outras partes foram submetidas aos campos elétricos e magnéticos, separadamente. $\mathrm{Na}$ tabela 7 , estão apresentadas as características da fonte de gamas.

Tabela 7 - Características da GammaCell.

\begin{tabular}{l|l}
\hline Capacidade Total & $37 \mathrm{PBq}$ (1 milhão de Curies) \\
\hline Atividade Inicial de Operação & $3,7 \mathrm{PBq}(100 \mathrm{kCi})$ \\
\hline Sistema de Irradiação & Product overlapping source \\
\hline Capacidade da Câmara & $4,32 \mathrm{~m}^{3}$ \\
\hline Energia Co-60 & $1,25 \mathrm{MeV}$ \\
\hline Tempo a cada 2kGy & $50 \mathrm{~min}$ \\
\hline Taxa de Dose & $2,4 \mathrm{kGy} / \mathrm{h}$ \\
\hline Formato da Fonte & $4 \pi$ \\
\hline
\end{tabular}

\subsection{Gama Combinada com Campos Elétrico e Magnético}

Após serem irradiadas com gamas, uma parte das amostras em tubos de $2 \mathrm{ml}$ foi plaqueada em meio sólido para obtenção da curva de sobrevivência com gamas; a segunda parte das amostras irradiadas foi submetida ao campo elétrico (figuras 13-15) e a última parte submetida ao campo magnético (figuras 16 e 17).

O sistema de tratamento com campo elétrico estático (CEE) foi desenvolvido usando uma fonte de alta voltagem que opera entre 0 e $10 \mathrm{kV}$. Esta fonte foi conectada através de dois eletrodos a um capacitor de placas circulares paralelas de alumínio ( $25 \mathrm{~cm}^{2}$ de diâmetro) com um intervalo de $1 \mathrm{~cm}$ entre as placas.

As amostras ficaram expostas ao campo elétrico de intensidade de 2 $\mathrm{kV} / \mathrm{cm}$ e magnético de 0,4 Tesla por 10 horas ininterruptamente. Em todos os casos, as amostras ficaram em temperatura ambiente para excluir efeitos térmicos. 
Este procedimento foi realizado pelos métodos citados no item 3.10.

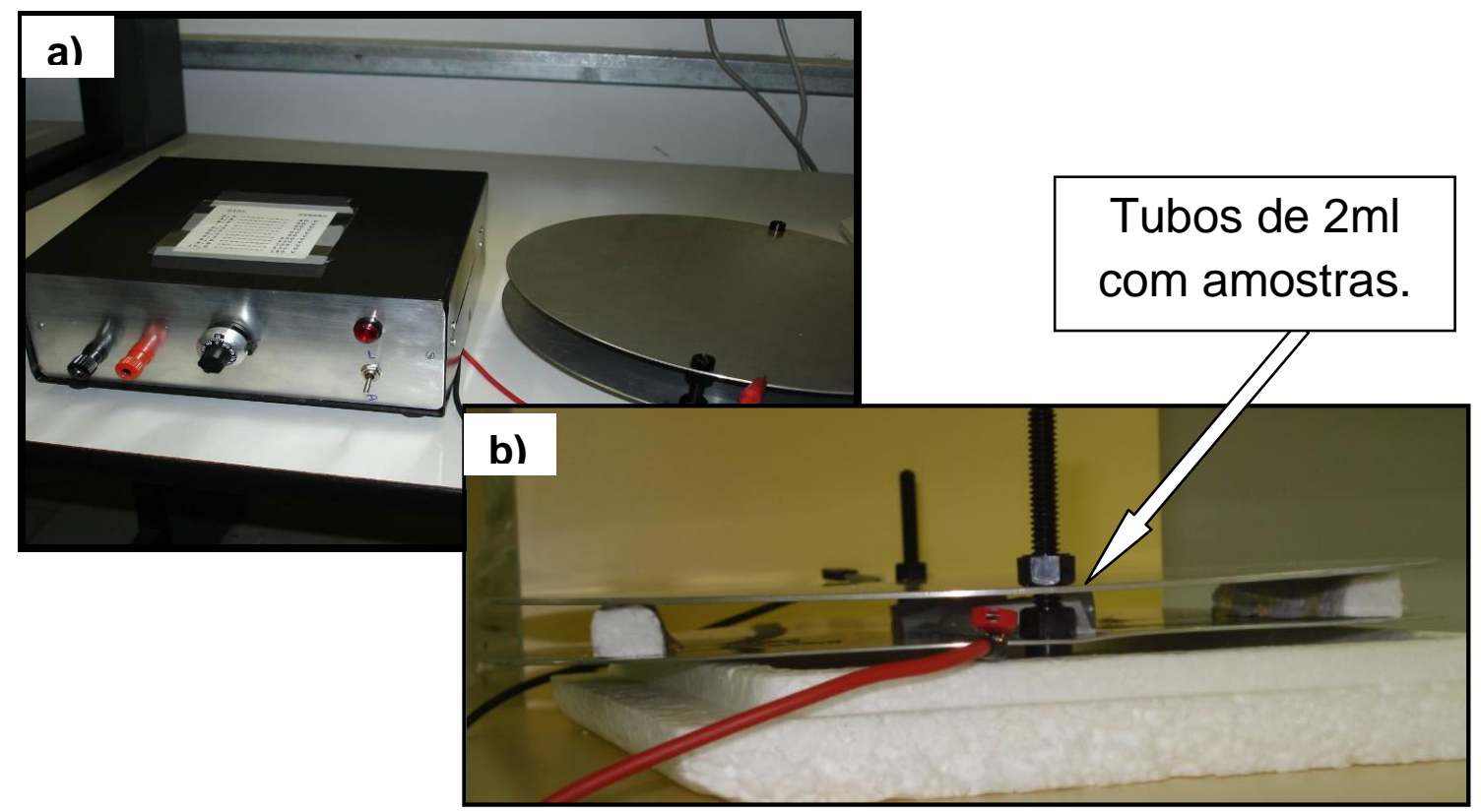

Figura 13: A) Arranjo do campo elétrico e B) Localização dos tubos com as amostras de $D$. radiodurans submetidas ao campo elétrico.

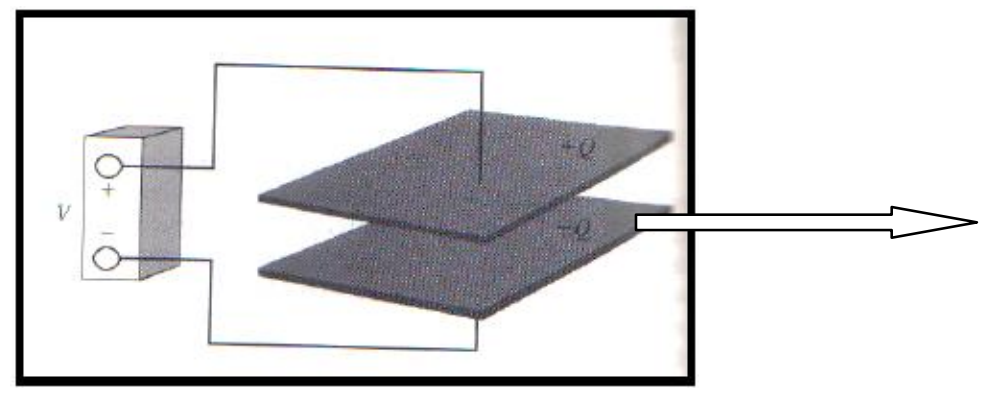

\begin{tabular}{|c|}
\hline Local onde o \\
material foi \\
depositado para \\
ação do campo \\
elétrico. \\
\hline
\end{tabular}

Figura 14: Capacitor plano de chapas paralelas do Campo Elétrico carregado com cargas de sinais opostos através de um gerador.

Fonte: Tipler, 1995. 


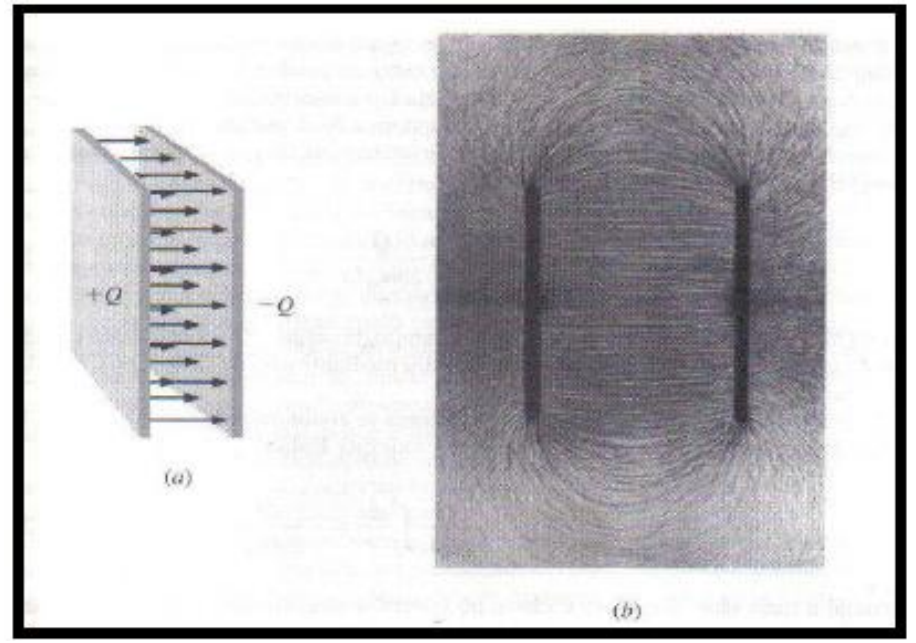

Figura 15: Direcionamento do campo elétrico entre um capacitor de chapas planas paralelas. Fonte: Tipler, 1995.

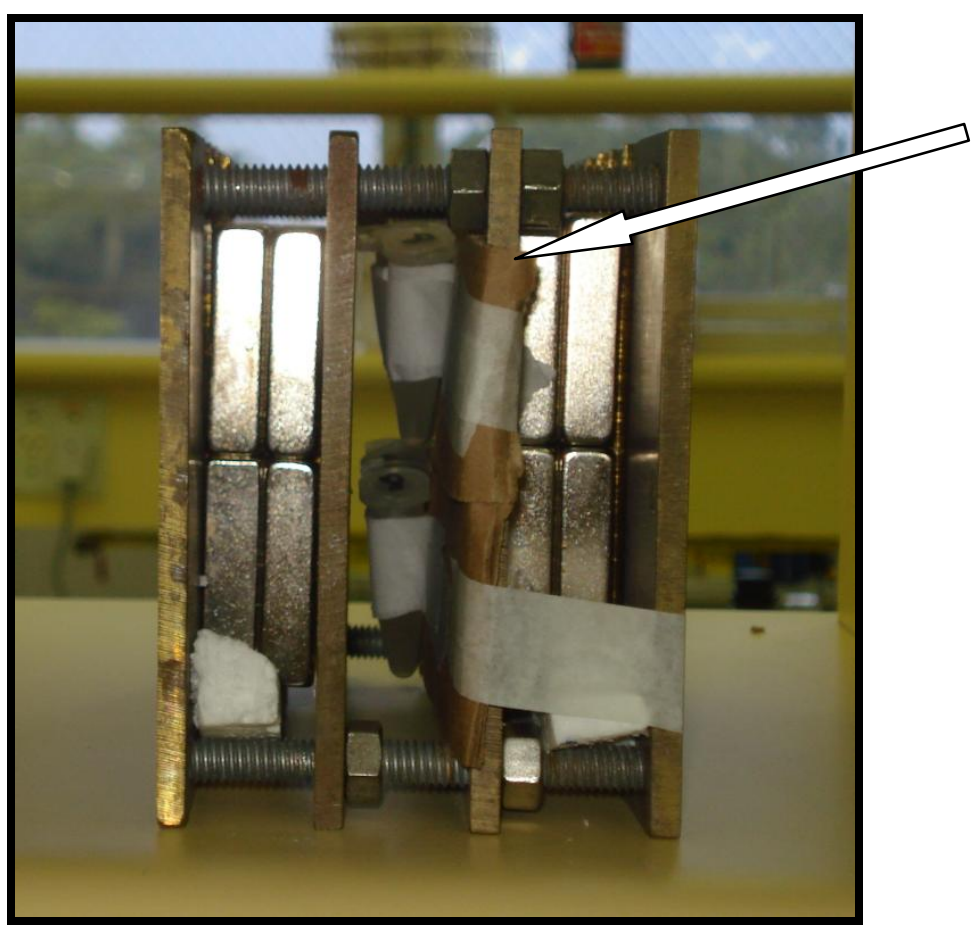

Tubos de $2 \mathrm{ml}$ com amostras.

Figura 16: Localização dos tubos com as amostras de $D$. radiodurans submetidas ao campo magnético. 


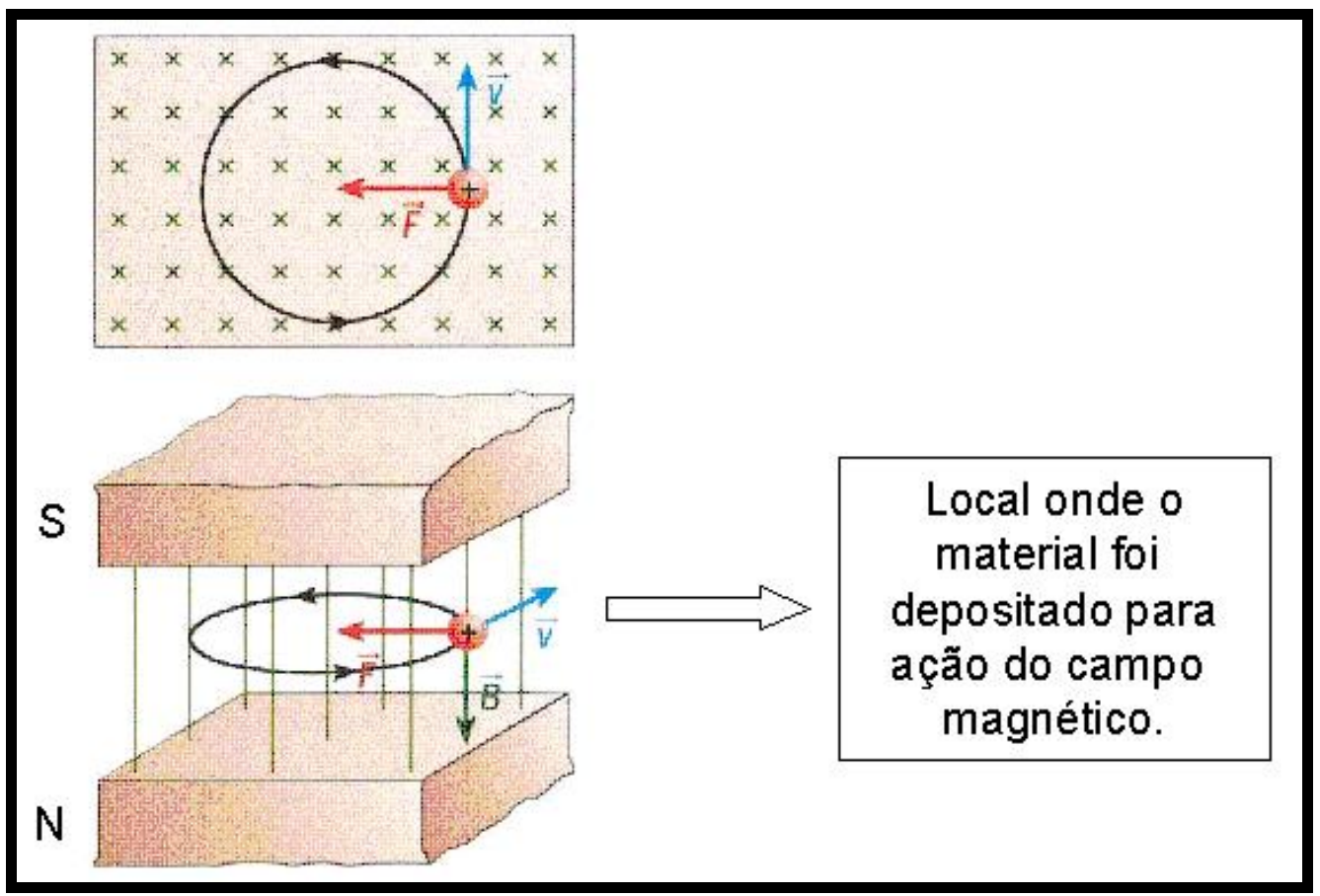

Figura 17: Direcionamento do campo magnético e localização das amostras.

\subsection{Preparo para Irradiação com Elétrons}

Após o preparo dos inóculos bacterianos (item 3.10), foram realizadas diluições seriadas e em seguida, as amostras foram plaqueadas (volume de $100 \mu \mathrm{l})$ em seu respectivo meio de cultura sólido. Em seguida, retirou-se a tampa, e as placas Petri foram embaladas com plástico filme e levadas para irradiação no acelerador linear.

\subsection{Características do Acelerador Linear}

As amostras expostas a elétrons também foram irradiadas no CTRIPEN, Centro de Tecnologia das Radiações, do Instituto de Pesquisas Energéticas e Nucleares, da Comissão Nacional de Energia Nuclear - CNEN.

Após atingirem as fases exponencial e estacionária, as amostras passaram pelo processo de diluição seriada e plaqueamento em seu respectivo 
meio de cultura sólido para em seguida serem irradiadas em acelerador de elétrons (figura 18), conforme características apresentadas nas tabelas 8 e 9.
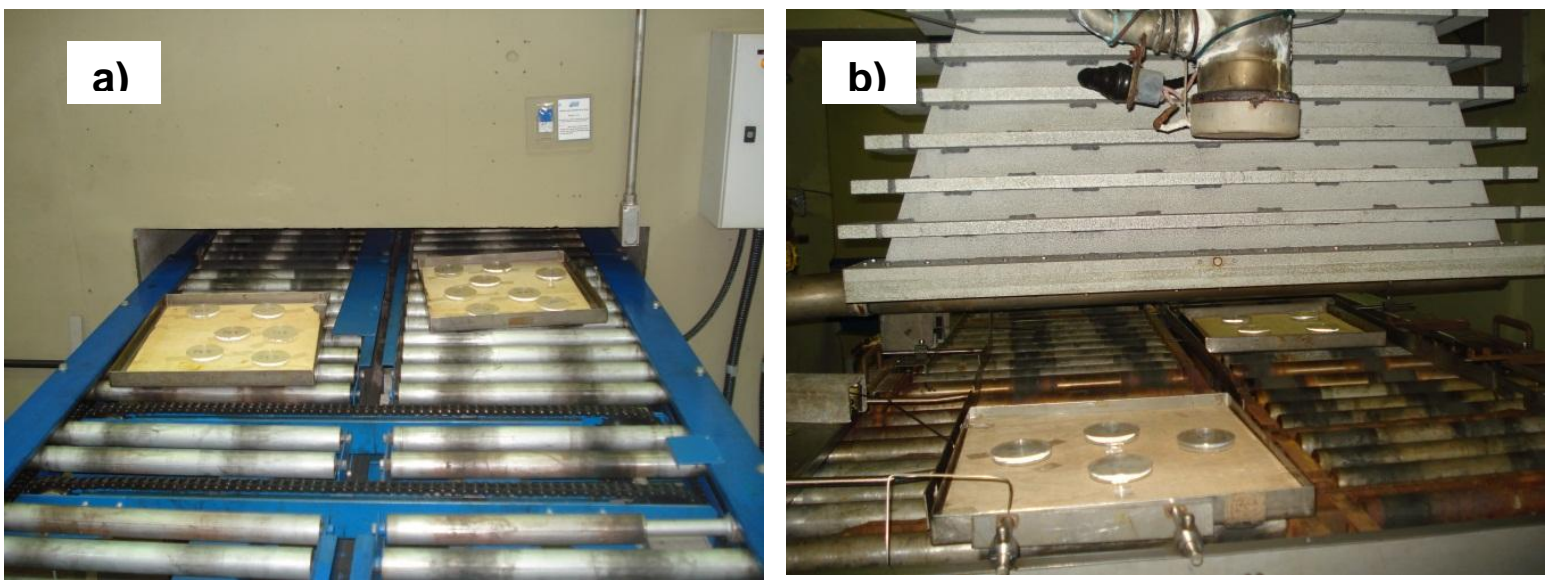

Figura 18: Irradiador de elétrons (LINAC). A) Esteira por onde as amostras deslizam até o feixe: B) Posição das amostras, abaixo do feixe de elétrons.

Tabela 8 - Características do Linac.

\begin{tabular}{l|l}
\hline MODELO & Dynamitron DC 1500/25/4 - job 188 \\
\hline FABRICANTE & Radiation Dynamics Inc. \\
\hline ENERGIA & $1,174 \mathrm{MeV}$ \\
\hline FABRICANTE & RDI RADIATION DYNAMICS, INC \\
\hline LARGURA de VARREDURA do FEIXE & $60 \mathrm{~cm}$ (mínima) a $120 \mathrm{~cm}$ (máxima) \\
\hline ESPESSURA do FEIXE: & $\pm 25,4 \mathrm{~mm}$ \\
\hline FREQÜÉNCIA da VARREDURA & $100 \mathrm{~Hz}$ \\
\hline
\end{tabular}

Tabela 9 - Características Dos feixes de elétrons.

\begin{tabular}{|c|c|c|c|}
\hline \multicolumn{4}{|c|}{ Stopping Power $\left(\mathrm{MeV} \mathrm{cm}^{2} / \mathrm{g}\right)$} \\
\hline Energia (MeV) & Colisão & Radioativo & Tota \\
\hline 1,00 & 1,849 & $1,280 \times 10^{-2}$ & 1,861 \\
\hline 1,25 & 1,828 & $1,600 \times 10^{-2}$ & 1,844 \\
\hline
\end{tabular}

Fonte: http://physics.nist.gov/cgi-bin/Star/e_table-u.pl

As amostras em meio sólido submetidas à irradiação com elétrons seguiram as condições especificadas na tabela 10: 
Tabela 10 - Características das amostras para o Linac.

\begin{tabular}{c|c|c}
\cline { 2 - 3 } & D. radiodurans & E. coli \\
\hline Densidade da amostra & $1 \mathrm{~g} / \mathrm{cm}^{3}$ & $1 \mathrm{~g} / \mathrm{cm}^{3}$ \\
\hline Espessura da amostra & $3 \mathrm{~mm}$ & $3 \mathrm{~mm}$ \\
\hline Densidade do Ágar & $1 \mathrm{~g} / \mathrm{cm}^{-1}$ & $1 \mathrm{~g} / \mathrm{cm}^{-1}$ \\
\hline Dose por passada & $0,5 \mathrm{kGy}$ & $0,29 \mathrm{kGy}$ \\
\hline Faixa de Dose & $1-12 \mathrm{kGy}$ & $0,5-4 \mathrm{kGy}$ \\
\hline Taxa de dose & $8,07 \mathrm{kGy} / \mathrm{h}$ & $4,68 \mathrm{kGy} / \mathrm{h}$ \\
\hline Número de passadas & 24 passadas & $14 \mathrm{passadas}$ \\
\hline Tempo de 1 passada & $0,223 \mathrm{~s}$ & $0,223 \mathrm{~s}$ \\
\hline Velocidade da esteira & $6,72 \mathrm{~m} / \mathrm{min}$ & $6,72 \mathrm{~m} / \mathrm{min}$ \\
\hline Corrente do Feixe & $0,49 \mathrm{~mA}$ & $0,31 \mathrm{~mA}$ \\
\hline Largura do Feixe & $100 \mathrm{~cm}$ & $112 \mathrm{~cm}$ \\
\hline \multicolumn{2}{|c}{}
\end{tabular}




\section{Resultados e Díscussão}


O estudo da resistência e sensibilidade da bactéria $D$. radiodurans a diferentes tipos de agentes físicos externos foi realizado por meio de análise de viabilidade celular nas fases de crescimento exponencial e estacionária, com a obtenção das respectivas curvas de crescimento.

Os resultados serão apresentados em 2 partes:

(i) irradiações com gamas e exposição a campos elétricos e magnéticos; e

(ii) irradiações com feixes de elétrons.

\subsection{Irradiações com Gamas e Exposição a Campos Elétricos e Magnéticos}

\subsection{Curvas de Crescimento}

As bactérias das cepas de $E$. coli e de $D$. radiodurans foram cultivadas em meio LB e TGY, respectivamente. As amostras foram colhidas a cada hora para medida de DO e plaqueadas para verificarmos o número de colônias obtidas (UFC/ml).

As figuras 19 e 20 representam as curvas de viabilidade obtidas por medidas de DO e UFC/ml, respectivamente. As barras de erro exibidas nessas figuras correspondem às incertezas estatísticas das medidas, realizadas em triplicata. 


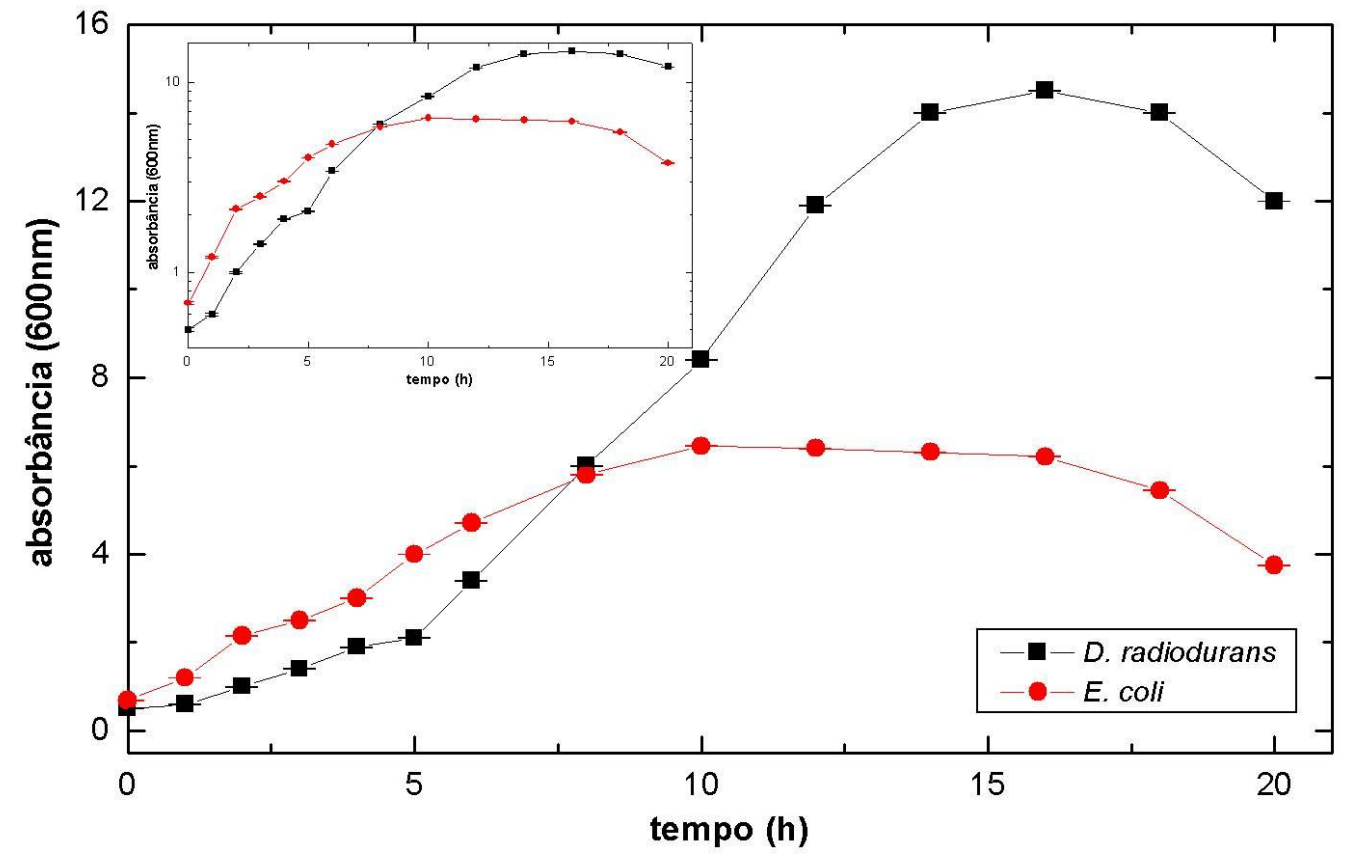

Figura 19: Curvas de crescimento da $D$. radiodurans e $E$. coli, obtidas por medidas de DO e incerteza de $0,001 \%$. Inserção: Curvas de crescimento da $D$. radiodurans e $E$. coli, obtidas por medidas de DO e incerteza de $0,001 \%$, escala linear-log.

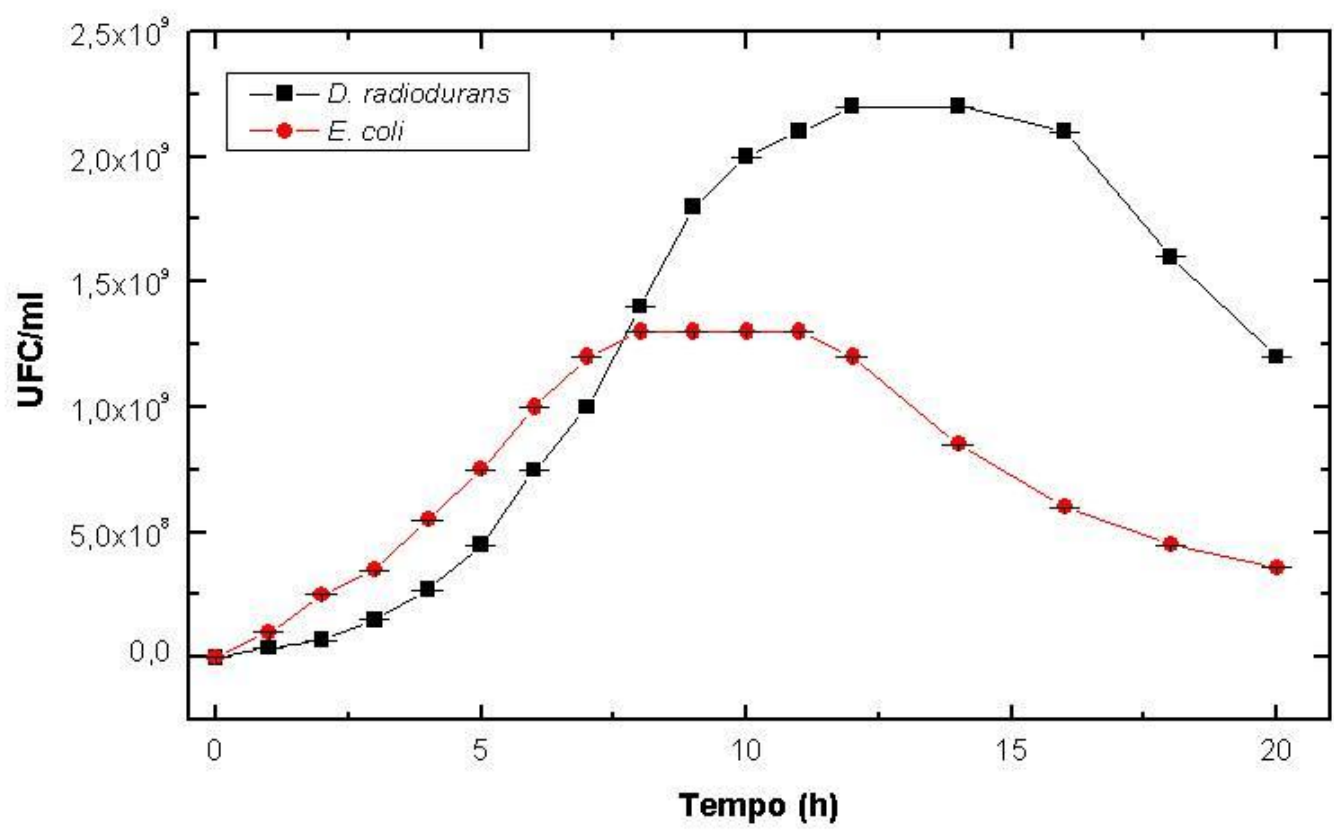

Figura 20: Curvas de crescimento da D. radiodurans e E. coli, obtidas por medidas de UFC/ml. 
A partir desses dados delineamos a fase exponencial e estacionária das linhagens bacterianas. As fases estabelecidas estão apresentadas na tabela 11:

Tabela 11 - Limites das fases exponencial e estacionária.

\begin{tabular}{c|c|c}
\hline Bactéria & Fase Exponencial & Fase Estacionária \\
\hline D. radiodurans & $4-10$ horas & $12-18$ horas \\
\hline E. coli & $4-8$ horas & $10-16$ horas \\
\hline
\end{tabular}

\subsection{Curvas de Sobrevivência}

\subsubsection{Irradiação com Gamas}

Uma vez delineada as fases de interesse do estudo passamos a irradiar as bactérias com gamas, em doses entre 0-12 kGy, e a partir de tempos de crescimento correspondentes ao início das fases exponencial e estacionária (tabela 11) $4 \mathrm{~h}$ e $14 \mathrm{~h}$ para a $D$. radiodurans, respectivamente.

Observamos na figura 21 que na fase estacionária a bactéria $D$. radiodurans, exposta à radiação gama, apresentou um ombro (conhecido como ombro de reparo, que representa a dose em que houve perda de $50 \%$ da viabilidade celular) estendendo-se de 0 a 8 kGy, em concordância com a literatura (NAIR et al., 2001). 


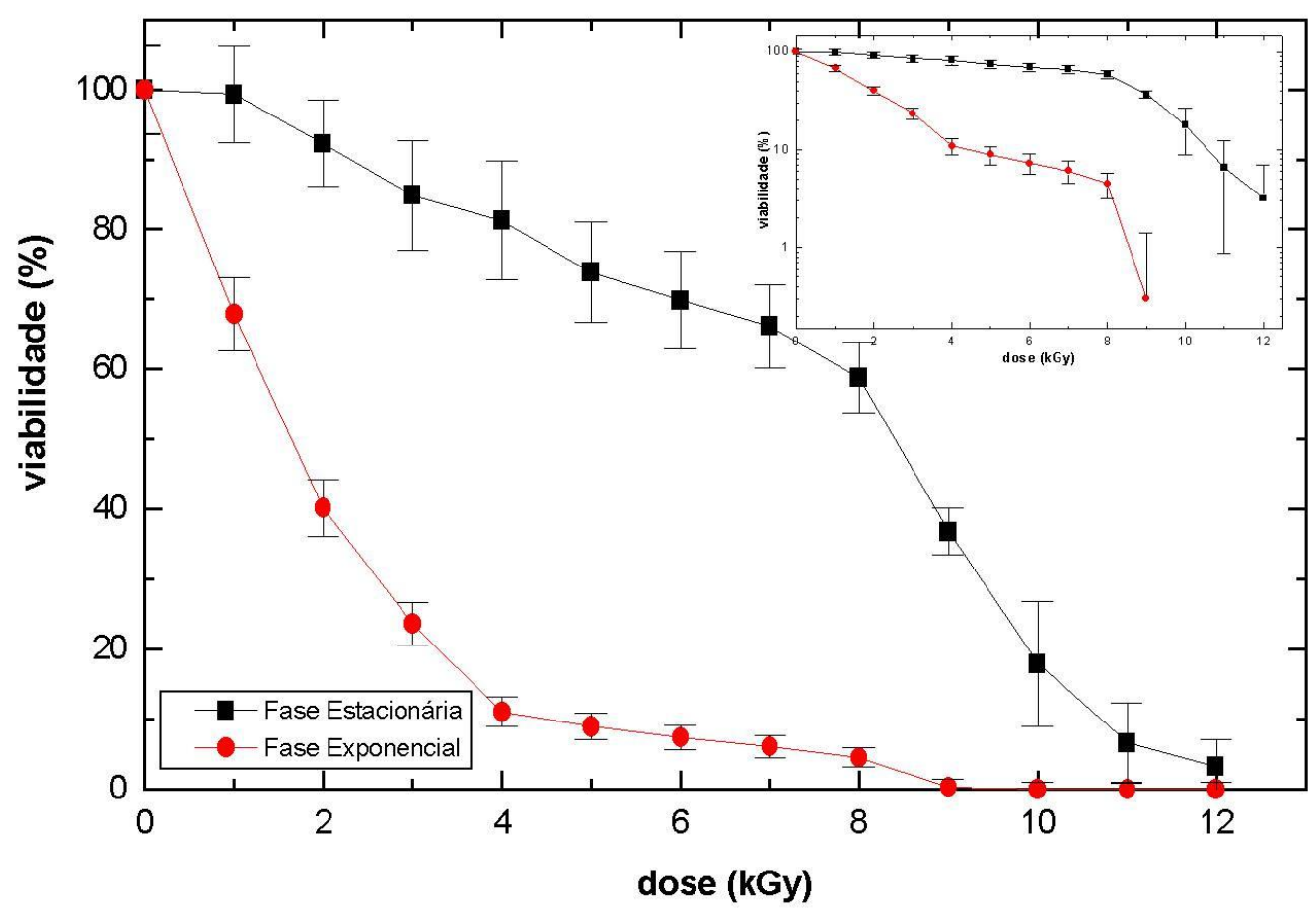

Figura 21: Curvas de sobrevivência da $D$. radiodurans nas fases estacionária e exponencial sob a ação de radiação gama. Inserção: Curvas de sobrevivência da $D$. radiodurans nas fases estacionária e exponencial sob a ação de radiação gama, escala linear-log.

Observamos, outrossim, que na fase estacionária para uma queda de $10 \%$ da população inicial é necessária uma dose de 3 kGy e na fase exponencial de apenas de $1 \mathrm{kGy}$. Observamos ainda que na fase exponencial a $D$. radiodurans é mais sensível à radiação gama comparativamente à fase estacionária, apresentando um ombro de apenas 2 kGy. Entretanto, ao observar a inserção da figura acima em escala linear-log constatamos que a $D$. radiodurans na fase exponencial não exibe visivelmente ombro de reparo.

$\mathrm{Na}$ fase exponencial as células estão em replicação muito ativa, ou seja, para cada tempo de geração há uma duplicação de todo o material celular. Nessas condições a célula pode possuir inclusive mais de uma cópia do material genético (MORON, 2008). No estado estacionário as células podem ainda estar se multiplicando, porém numa taxa muito menor que as células no 
estado exponencial (MORON, 2008; RAMSAY et al., 1995).

Escolhemos a $E$. coli como controle negativo para a $D$. radiodurans, seguindo os mesmos procedimentos para irradiações nas fases exponencial e estacionária. Observamos que com apenas 0,5 kGy houve uma queda de aproximadamente $50 \%$ da viabilidade celular (figura 22, mostrando ser essa bactéria bastante radiossensível, e em acordo com dados existentes na literatura (BATTISTA, 1997). A resposta da $E$. coli nas fases exponencial e estacionária é muito similar. Essa circunstância é decorrência da grande radiossensibilidade da bactéria ( $D_{0}$ de $3 \mathrm{kG}$, aproximadamente), diminuindo em muito as diferenças entre as fases.

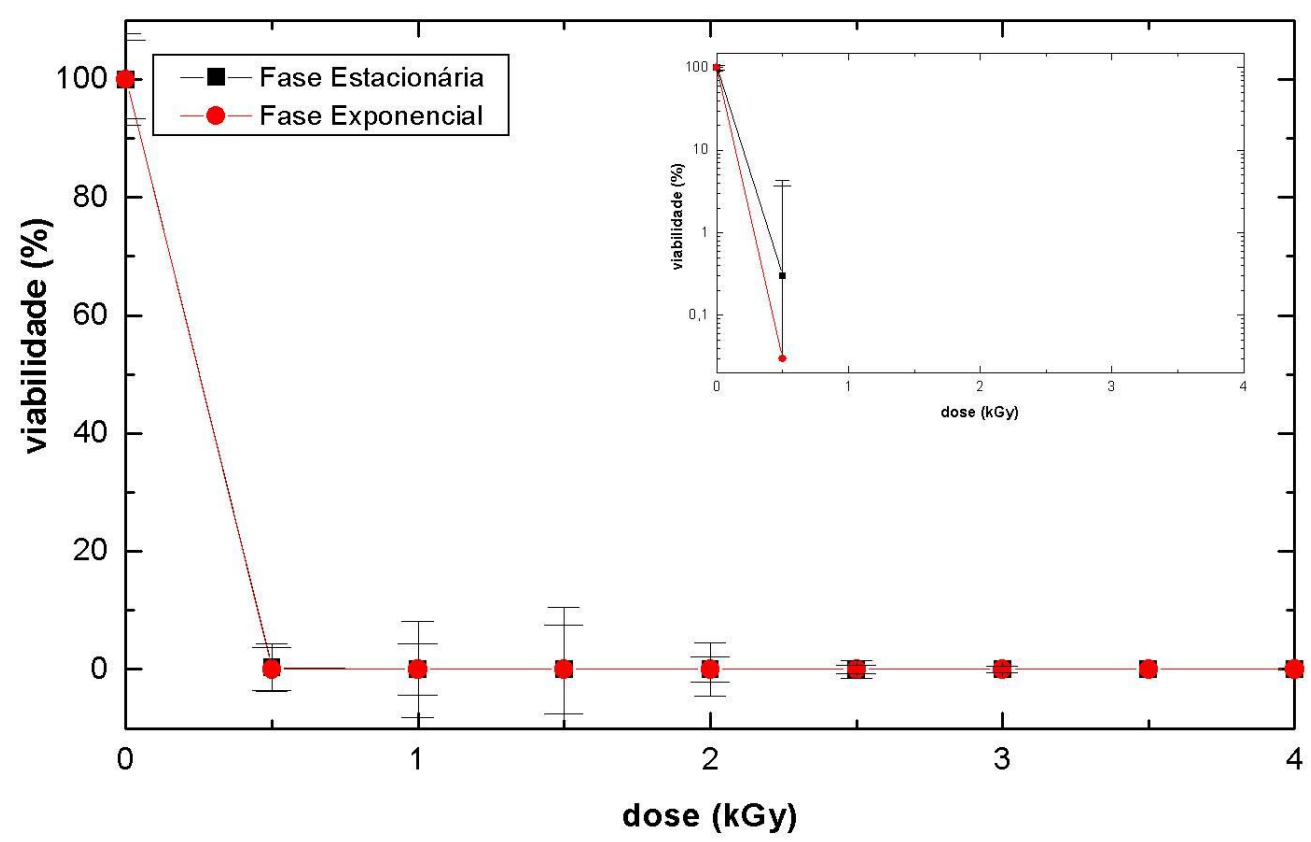

Figura 22: Curvas de sobrevivência da E. coli nas fases estacionária e exponencial sob a ação de radiação gama. Inserção: Curvas de sobrevivência da $E$. coli fases estacionária e exponencial sob a ação de radiação gama, escala linear-log.

Para atingir a dose de 8 kGy a GammaCell leva aproximadamente 4 horas (taxa de dose $2 \mathrm{kGy} /$ hora, aproximadamente). 
Sukhi et al. (2009) realizaram experimentos com a $D$. radiodurans $\mathrm{R} 1 \mathrm{em}$ diferentes fases e tempos de crescimento. Foram utilizadas amostras no início da fase exponencial, $4 \mathrm{~h}$, no meio da fase exponencial, $6 \mathrm{~h}$ e $8 \mathrm{~h}$, no final da fase estacionária, $18 \mathrm{~h}$, e nos tempos de 38 e $48 \mathrm{~h}$, denominados pelos autores (Sukhi et al., 2009) de "fase estacionária tardia". Eles Observaram que a $D$. radiodurans $\mathrm{R} 1$ apresentou a mesma radioresistência para o início e meio da fase exponencial (4, 6 e 8 h) e para o final da fase estacionária (18 h). Entretanto, na "fase estacionária tardia" (38 e 48 h) a bactéria apresentou grande sensibilidade, contradizendo o estudo de Keller e Maxcy (1984), que afirma que o meio da fase estacionária é mais resistente do que a fase exponencial. Entretanto, no seu estudo, Sukhi et al. (2009) irradiaram as amostras fazendo antes um ajuste da suspensão celular de forma que a concentração inicial fosse aproximadamente a mesma $\left(10^{8} \mathrm{cel} / \mathrm{ml}\right)$ para as fases exponencial e estacionária. A razão para este comportamento "anômalo", nas palavras de Sukhi, ou seja, mesma radioresistência em diferentes fases do crescimento, não foi identificada em seu estudo. Esses autores argumentaram que talvez a explicação fosse obtida através de estudos envolvendo a fisiologia de $D$. radiodurans.

Para verificar a consistência dos resultados de Sukhi et al., 2009 em relação a este estudo, também realizamos irradiações com o mesmo ajuste da suspensão celular. Contudo, foram estabelecidos os seguintes tempos de cultivo para irradiações nas fases de crescimento: meio da fase exponencial (8 h) e final da fase estacionária (18 h). Os resultados são apresentados na figura 23. 


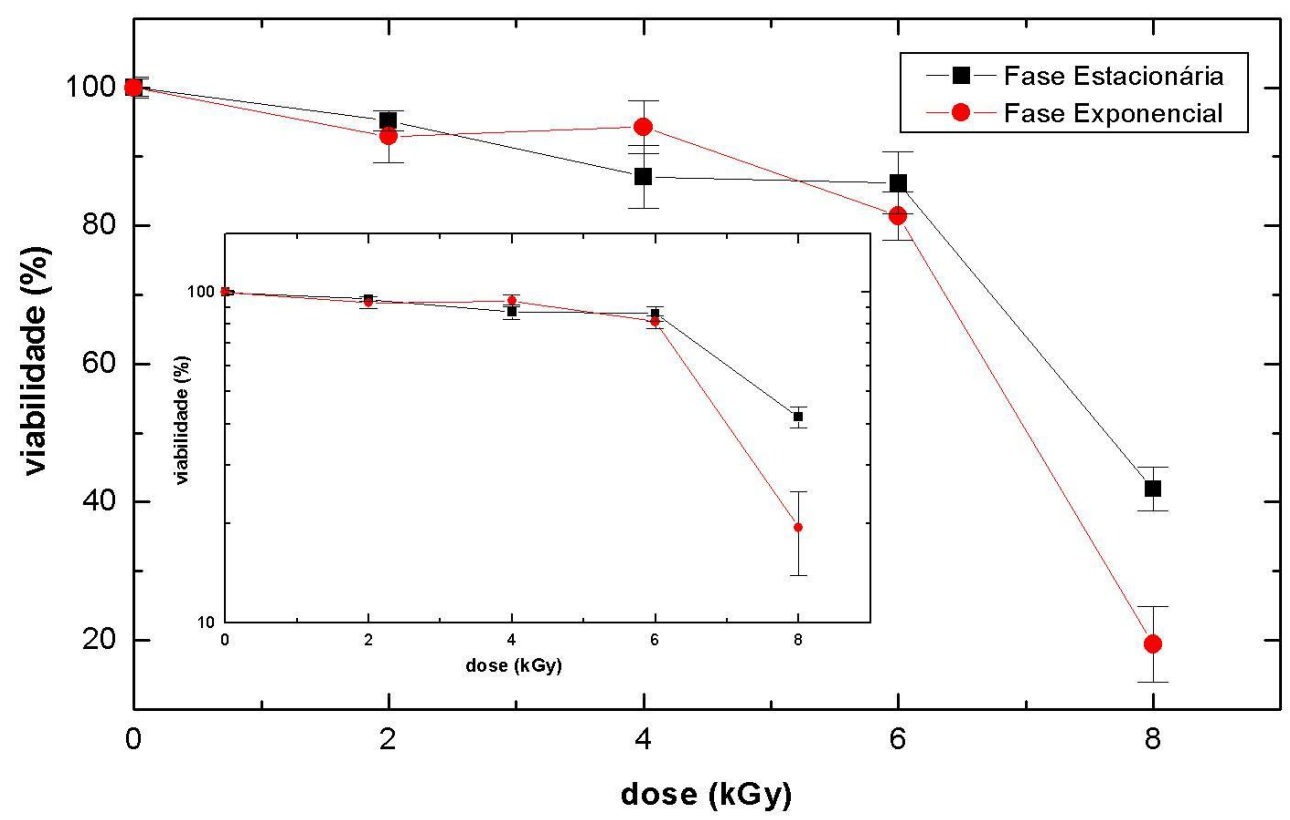

Figura 23: Curvas de sobrevivência da $D$. radiodurans nas fases estacionária e exponencial sob a ação de radiação gama com ajuste na suspensão celular. Inserção: Curvas de sobrevivência da $D$. radiodurans fases estacionária e exponencial sob a ação de radiação gama com ajuste da suspensão celular, escala linear-log.

Observamos que com ajuste celular a $D$. radiodurans apresenta um ombro de reparo de $6 \mathrm{kGy}$ em ambas as fases de crescimento, ou seja, radioresistência similar em ambas as fases [meio da fase exponencial $(8 \mathrm{~h}) \mathrm{e}$ final da fase estacionária $(18 \mathrm{~h})$ ]. Porém, nas irradiações realizadas sem 0 ajuste celular (figura 21), a $D$. radiodurans apresenta maior radioresistência no início da fase estacionária (14 h) do que no início da fase exponencial $(4 \mathrm{~h})$, corroborando o estudo de Keller e Maxcy (1984). Isso significa que o número de células presente nas amostras irradiadas é o fator determinante da resistência de $D$. radiodurans, e não a fase de crescimento específica. É importante observar que o ombro de reparo na fase estacionária não é sensível ao ajuste celular, enquanto que na fase exponencial o ombro triplicou quando procedeu-se ao ajuste celular.

Se refletirmos em relação à radioterapia aplicada em tumores, os resultados apresentados com ajuste da suspensão celular não representam a 
realidade de um tumor sólido, pois um tumor pode se apresentar em diferentes partes do corpo ou se espalhar por todo o corpo (metástase), e assim, não é possível regular o número de células que ele possui, ao contrário dos resultados com ajuste celular. Assim, nossos ensaios foram realizados sem ajuste da suspensão celular.

\subsubsection{Irradiação com Gamas e Exposição ao Campo Elétrico}

A utilização simultânea de irradiação com agentes físicos exógenos (como campos elétricos estáticos e calor) foi estudada teoricamente com modelos biofísicos (ARRUDA-NETO et al., 2009). De acordo com esses resultados teóricos, os agentes físicos mencionados atuariam nas células irradiadas no sentido de dificultar (atrasar ou impedir) os mecanismos de reparo. Com isso, seria acionado o mecanismo de morte programada diminuindo, consequentemente, a radioresistência do microrganismo.

A ação de campos elétricos exógenos, seguindo exposição da $D$. radiodurans à radiação gama, foi quantificada com a aplicação de um campo de $2 \mathrm{kV} / \mathrm{cm}$ ininterruptamente por 10 horas, e com doses entre 0 e 8 kGy (limites do ombro de reparo). Nessa faixa de dose a $D$. radiodurans é muito proficiente em reparo constituindo, portanto, um teste extremo para a citotoxicidade do campo elétrico.

A figura 24 mostra resultados para a $D$. radiodurans na fase estacionária, submetida à radiação gama com doses de 2 a 8 kGy e em seguida exposta ao campo elétrico por $10 \mathrm{~h}$. 


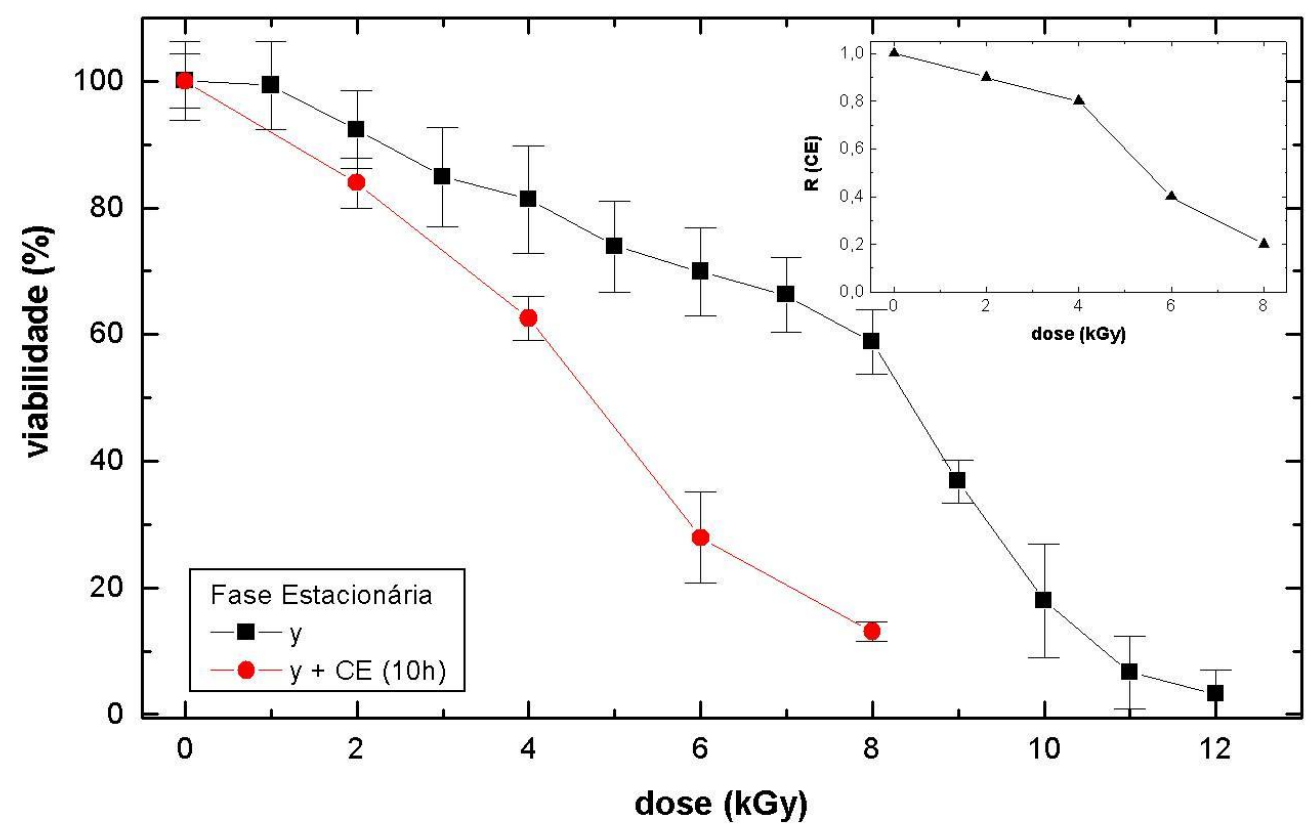

Figura 24: Curvas de sobrevivência da $D$. radiodurans na fase estacionária, sob a ação de radiação gama e radiação gama + campo elétrico de $10 \mathrm{~h}$. Inserção: Gráfico Relativo $(\gamma+\mathrm{CE} / \gamma$ - detalhes no texto) da $D$. radiodurans na fase estacionária, sob a ação radiação gama combinada com campo elétrico de $10 \mathrm{~h}$.

Observamos que o ombro de reparo que se manifestava até 8 kGy, somente com radiação gama, diminuiu para $4 \mathrm{kGy}$ com a ação do campo elétrico (CE) - redução de $50 \%$-, além de uma queda abrupta em doses acima de 4 kGy. Isso demonstra que o campo elétrico combinado com radiação gama ( $\gamma$ ) é bastante citotóxico para $D$. radiodurans na fase estacionária. Na inserção (figura 24) temos a razão entre as duas curvas de sobrevivência: $R=S(y+C E) / S(y)$, em que $\mathrm{S}(\gamma+\mathrm{CE})$ e $\mathrm{S}(\gamma)$ representam às viabilidades celulares correspondentes as irradiações com e sem aplicação do campo elétrico, respectivamente. Em $8 \mathrm{kGy}$, por exemplo, temos $R \approx 0,2$, ou seja, o CE foi responsável por uma perda adicional de viabilidade de aproximadamente $80 \%$ nessa dose (tabela 12 ). 
Tabela 12 - Taxa entre as duas curvas de sobrevivência (figura 24 - inserção).

\begin{tabular}{c|c|c|c|c|c}
\cline { 2 - 6 } & \multicolumn{5}{c}{ Gráfico Relativo: $\gamma+\mathbf{C E} / \gamma$} \\
\hline Dose (kGy) & $\mathbf{0}$ & $\mathbf{2}$ & $\mathbf{4}$ & $\mathbf{6}$ & $\mathbf{8}$ \\
\hline Fase Estacionária & 1,00 & 0,91 & 0,77 & 0,40 & 0,20 \\
\hline
\end{tabular}

Na figura 25 apresentamos resultados de irradiação na fase exponencial e exposição ao campo elétrico por $10 \mathrm{~h}$. Observamos que nessa fase o efeito isolado da radiação gama já foi bastante citotóxico (ombro de $2 \mathrm{kGy}$ ), tornando assim o efeito do campo elétrico muito pequeno (ombro de $1 \mathrm{kGy}$ ), como era de se esperar.

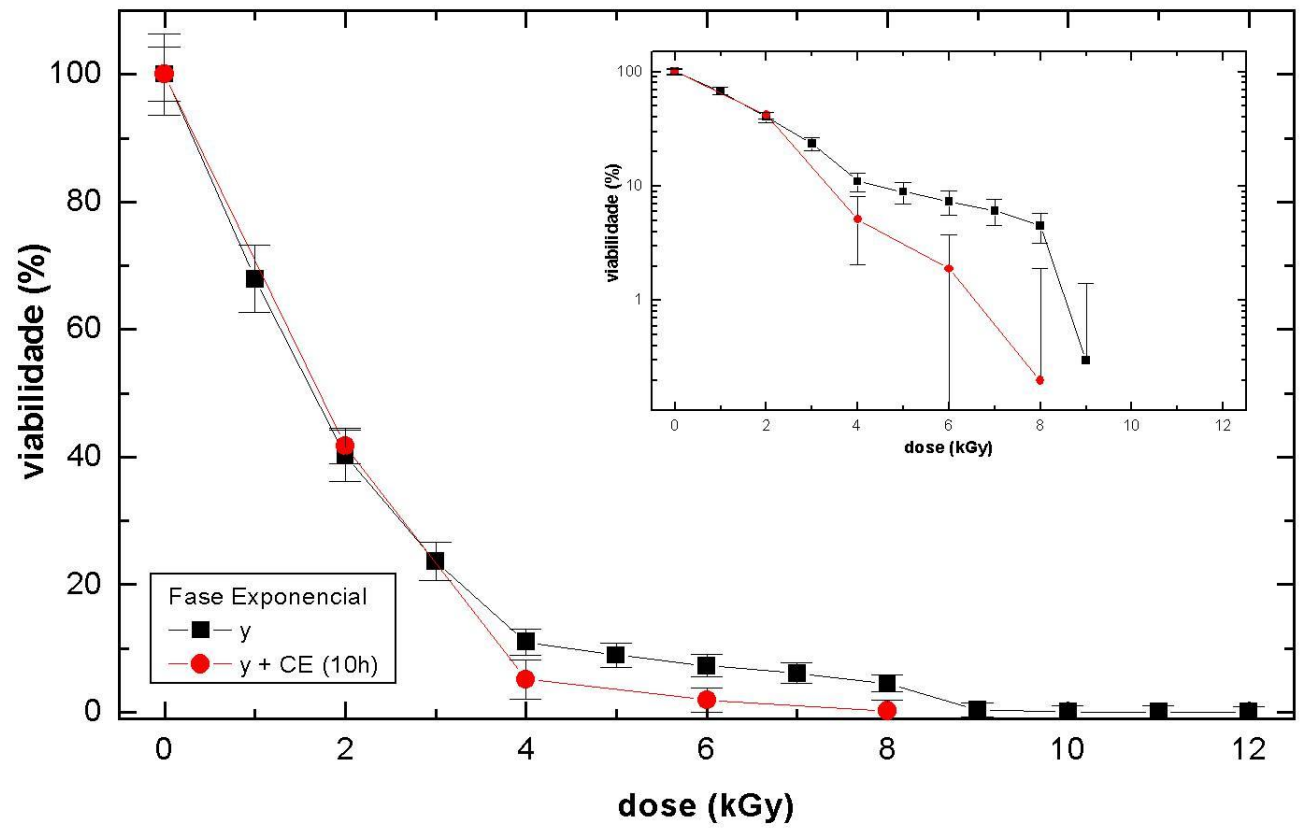

Figura 25: Curvas de sobrevivência da $D$. radiodurans na fase exponencial, sob a ação de radiação gama e radiação gama + campo elétrico de $10 \mathrm{~h}$. Inserção: Curvas de sobrevivência da $D$. radiodurans na fase exponencial, sob a ação de radiação gama e radiação gama + campo elétrico de $10 \mathrm{~h}$, escala linear-log.

A fim de visualizarmos melhor os dados discutidos acima (figuras $24 \mathrm{e}$ 25) apresentamos na figura 26 os resultados da combinação de radiação gama com campo elétrico por $10 \mathrm{~h}$ para a $D$. radiodurans nas fases exponencial e 
estacionária.

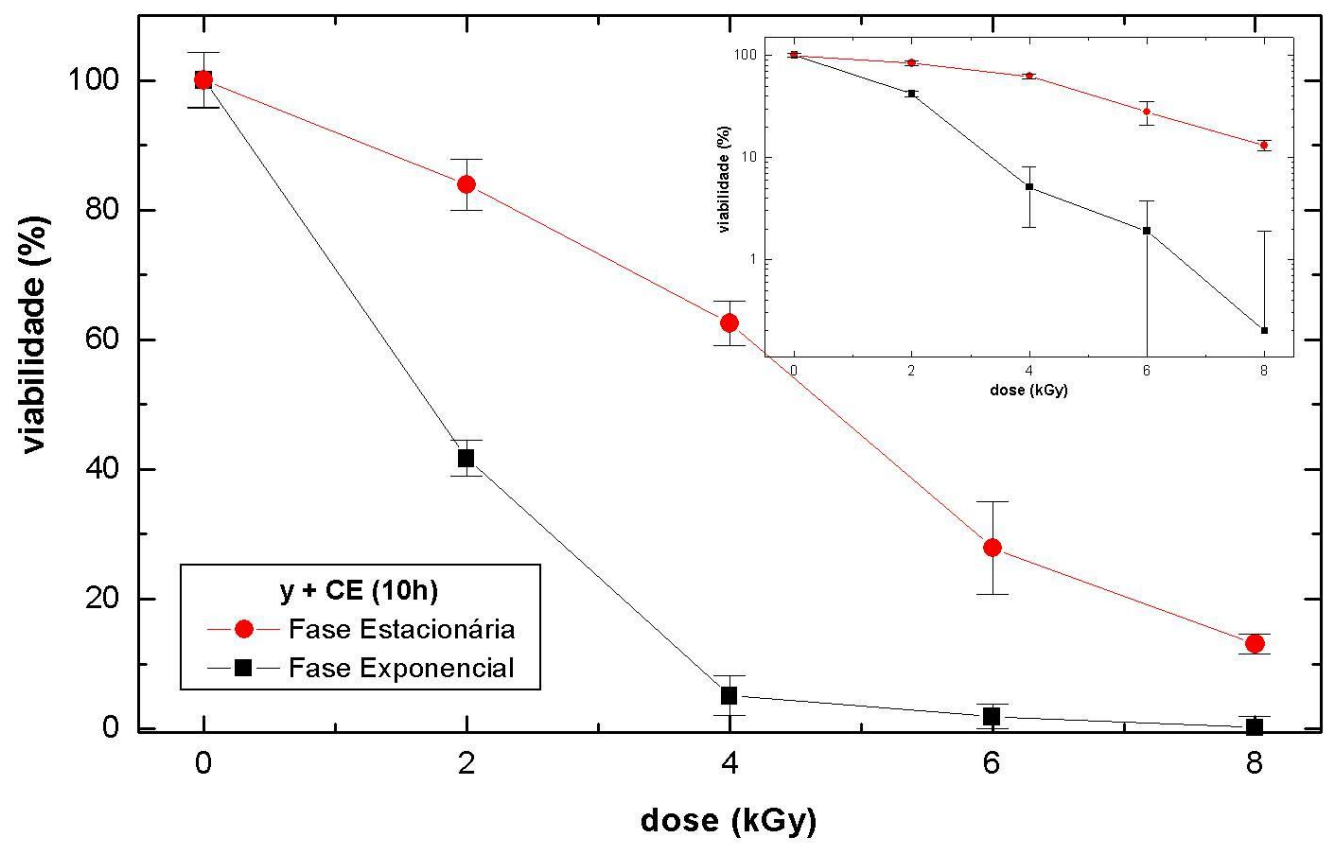

Figura 26: Curvas de sobrevivência da $D$. radiodurans nas fases estacionária e exponencial, sob a ação de radiação gama combinada com campo elétrico de $10 \mathrm{~h}$. Inserção: Curvas de sobrevivência da $D$. radiodurans nas fases estacionária e exponencial, sob a ação de radiação gama e radiação gama + campo elétrico de $10 \mathrm{~h}$, escala linear-log.

$\mathrm{Na}$ associação de gamas e CE obteve-se uma apreciável redução do ombro de reparo. $\mathrm{Na}$ inserção da figura 26 fica claro a manifestação do ombro de 4 kGy e 1 kGy nas fases exponencial e estacionária, respectivamente.

Contudo, a ausência de ombro de reparo já foi observada em eucarioto simples, Candida albicans. A curva de sobrevivência das amostras de C. albicans irradiadas e submetidas à ação de um campo elétrico com intensidade de $1.000 \mathrm{~V} / \mathrm{cm}$ (figura 27), revela que a ação combinada de irradiação com campo elétrico provoca maior e apreciável aumento de morte celular. No intervalo de doses 1-3 KGy ocorreu, em média, 40\% de morte celular, duas vezes mais do que o verificado somente com irradiação. (LOUVISON, 2007). Isso mostra que o efeito de radiações como gamas, não distingue organismo, 
trata-se de um "efeito universal" (figura 27).

Telló et al. (2004) explicam como ações combinadas de quimioterapia e de campo elétrico podem ser úteis na regressão e cura de tumores cancerígenos, pois esses fatores influenciam o ciclo celular e o perfil do potencial da membrana celular. Com isso, haveria alterações no crescimento e divisão celular.

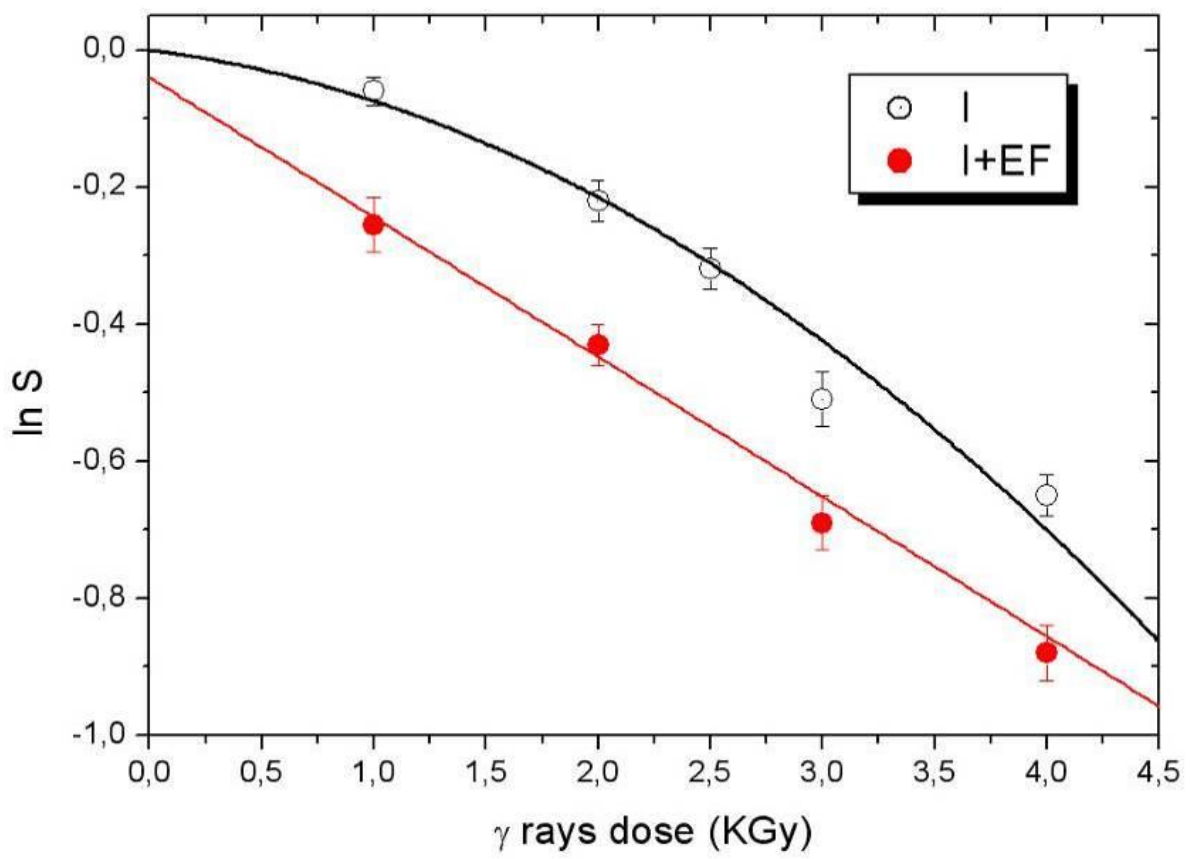

Figura 27: Curva de sobrevivência de $C$. albicans após irradiação e submetida ao campo elétrico. Fração de células sobreviventes (em escala de linear-log) em função da dose de irradiação gama: $\mathbf{I}$ = Irradiada e I+EF = Irradiada e submetida ao campo elétrico - 1000 Volts/cm.

Fonte: Louvison, 2007.

Nessa intensidade, o campo elétrico exerceu um papel citotóxico somente quando associado ao tratamento com irradiação gama. Essa circunstância sugere que o campo elétrico deve interferir nos processos de recuperação das células quando estas são submetidas a estresses radiológicos. Provavelmente o campo elétrico interferiu no processo de reparo, quando houve quebra da dupla fita, conforme mostra o esquema da figura 2 (CEE), onde ele reorienta e impede que as proteínas de reparo alcancem o sítio danificado (LOUVISON, 
2007).

\subsubsection{Proposição de um modelo Biofísico para $\gamma+$ CEE}

$\mathrm{Na}$ figura 28, propomos um modelo biofísico para o comportamento dos fragmentos de DNA de $D$. radiodurans quando expostos ao CEE após irradiação. Os fragmentos de DNA da $D$. radiodurans sem ação de um CEE se reconectam por homologia (considerando a homologia o mecanismo mais provável, figura 28-A). Entretanto, a exposição ao CEE polariza os dipolos elétricos dos fragmentos de DNA e proteínas, dificultando o rejunte, ou seja, o CEE orienta os fragmentos na direção do campo (figura 28-B), dificultando a reconecção de suas extremidades homólogas, impedindo assim, a reconstrução do genoma e o aumento da morte celular. Esste alinhamento é facilitado devido ao DNA da $D$. radiodurans ser circular. A redução do ombro de reparo da $D$. radiodurans as exposições ao CEE comprova este raciocínio.
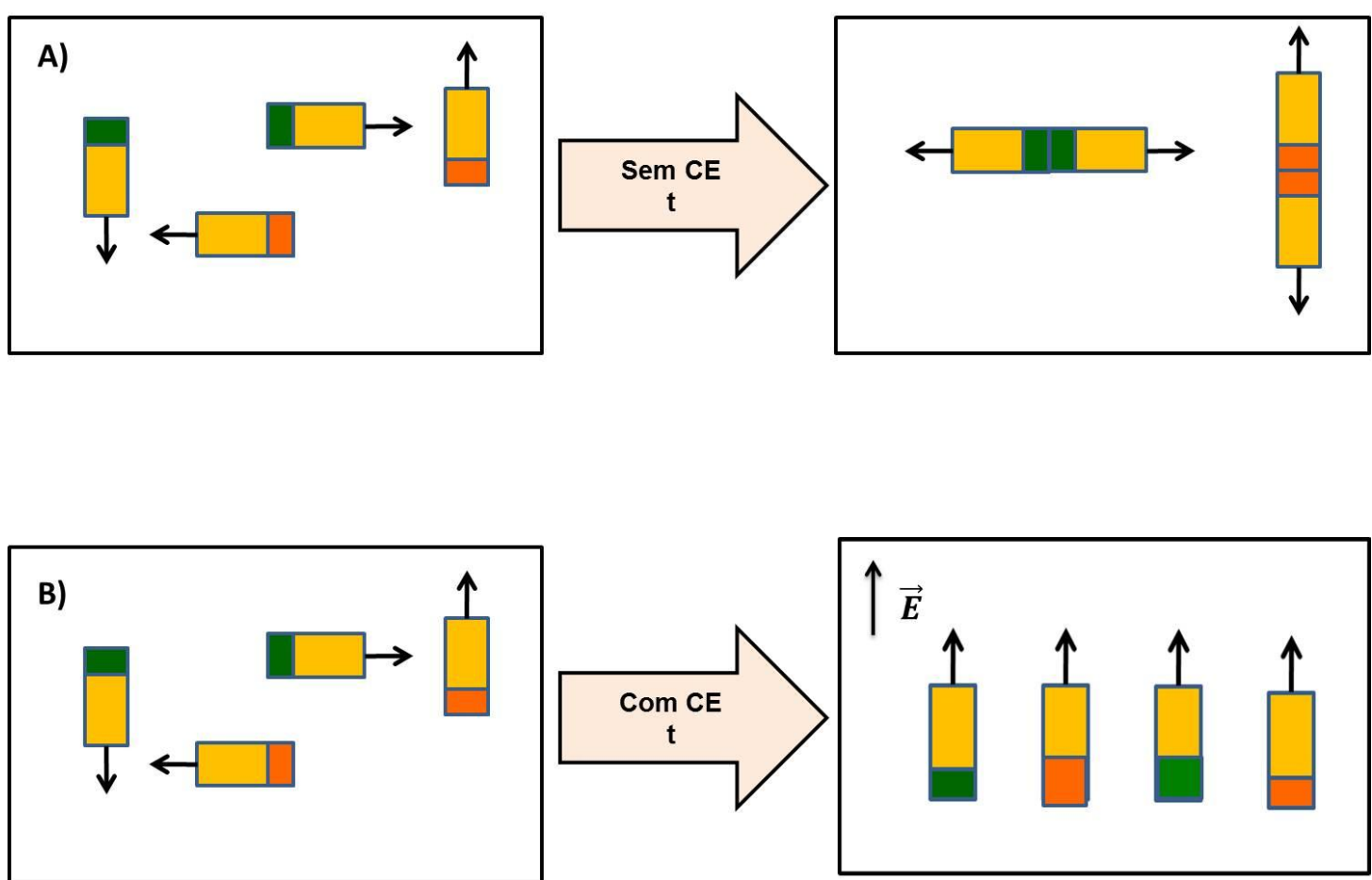

Figura 28: Esquema ilustrativo do modelo biofísico da ação do CEE aos fragmentos de DNA. 
Nos experimentos realizados, observa-se que a $D$. radiodurans apresenta um ombro de reparo de 8 kGy para irradiações com gamas. Entretanto, a ação combinada de gamas e campo elétrico reduz efetivamente 0 ombro para 4 kGy (fase estacionária). Campo elétrico estático sem nenhum tipo de associação, e de intensidade $(2 \mathrm{kV} / \mathrm{cm})$, a mesma utilizada neste estudo, não é citotóxico. A eletroporação só é alcançada com alta intensidade externa em campos pulsados (de várias centenas a milhares de $\mathrm{V} / \mathrm{cm}$ (ARRUDA-NETO, 2009)). Contudo, a ação combinada de radiação gama e campo elétrico apresentou ser altamente citotóxica.

O DNA de $D$. radiodurans apresenta-se ordenado em uma estrutura toroidal, semelhante a um anel (MADIGAN, 2004). O reparo é então facilitado pela fusão de nucleoides de compartimentos adjacentes, pois isso propicia uma plataforma para a recombinação homóloga. A partir dessa extensa recombinação, emerge um único cromossomo reparado, e a célula contendo esse cromossomo é capaz de crescer e dividir-se (ZAHRADKA, 2006).

A alta taxa de reparo aos danos do DNA exige da $D$. radiodurans alta homologia e precisão de seus mecanismos de reparo. Irradiações com altas doses causam centenas de pequenas quebras ao DNA. Pequenos fragmentos possuem pouca inércia e por isso, torna-se mais fácil o alinhamento desses ao campo elétrico, o que seria muito mais difícil ocorrer em fragmentos de um genoma de um eucarioto superior. Este alinhamento deve dificultar a reconexão dos fragmentos, em decorrência da redução da homologia e precisão (ZAHRADKA, 2006). Esse tipo de ação do CEE nos mecanismos de reparo da $D$. radiodurans, nunca foi antes observado em outros procariotos e eucariotos.

De fato, em células humanas a citotoxicidade de CEE associado à radiação gama é da ordem de $12 \%$, de acordo com medidas de viabilidade e foi constatado que a exposição ao CEE por $1 \mathrm{~h}$ com doses de 2 Gy altera a quantidade de histonas H2AX fosforiladas na linhagem normal de células humanas MRC5, interferindo assim, no processo convencional de reparo das quebras da dupla fita de DNA (DSBs). A análise e interpretação do ciclo celular também indicou que o CEE interferiu nesse processo de reparo do DNA, notadamente pelo maior acúmulo de células observado na fase $S$ (MORON, 2008). 
Segundo Zahradka (2006), a resistência de $D$. radiodurans presumivelmente evoluiu sob condições não-reprodutivas, tais como aquelas presentes em regiões áridas como desertos.

A alta resistência a situações extremas acompanhadas por extensos danos ao DNA leva à "Morte clínica" de suas células. Entretanto, em 1,5 h sem ação de agentes físicos e no seu meio de cultura, a bactéria morta "ressuscita", reconstituindo os danos (ZAHRADKA, 2006).

$\mathrm{Na}$ figura abaixo 29, Zahradka (2006), demonstra experimentalmente $\mathrm{O}$ quanto a $D$. radiodurans é eficiente em reparo. Depois de ser irradiada com $7 \mathrm{kGy}$ de gamas, os fragmentos de DNA de cerca de 20-30 Kpb foram analisados em eletroforese de campo pulsado. Observou-se que até 1,5 h após a irradiação não foi visível o reparo dos fragmentos de DNA, entretanto, $1,5 \mathrm{~h}$ após a irradiação, o DNA cromossômico apareceu totalmente remontado ou reconectado, representando uma sobrevivência de $80-90 \%$, remontando o genoma funcional de 3,28 Mpb. 


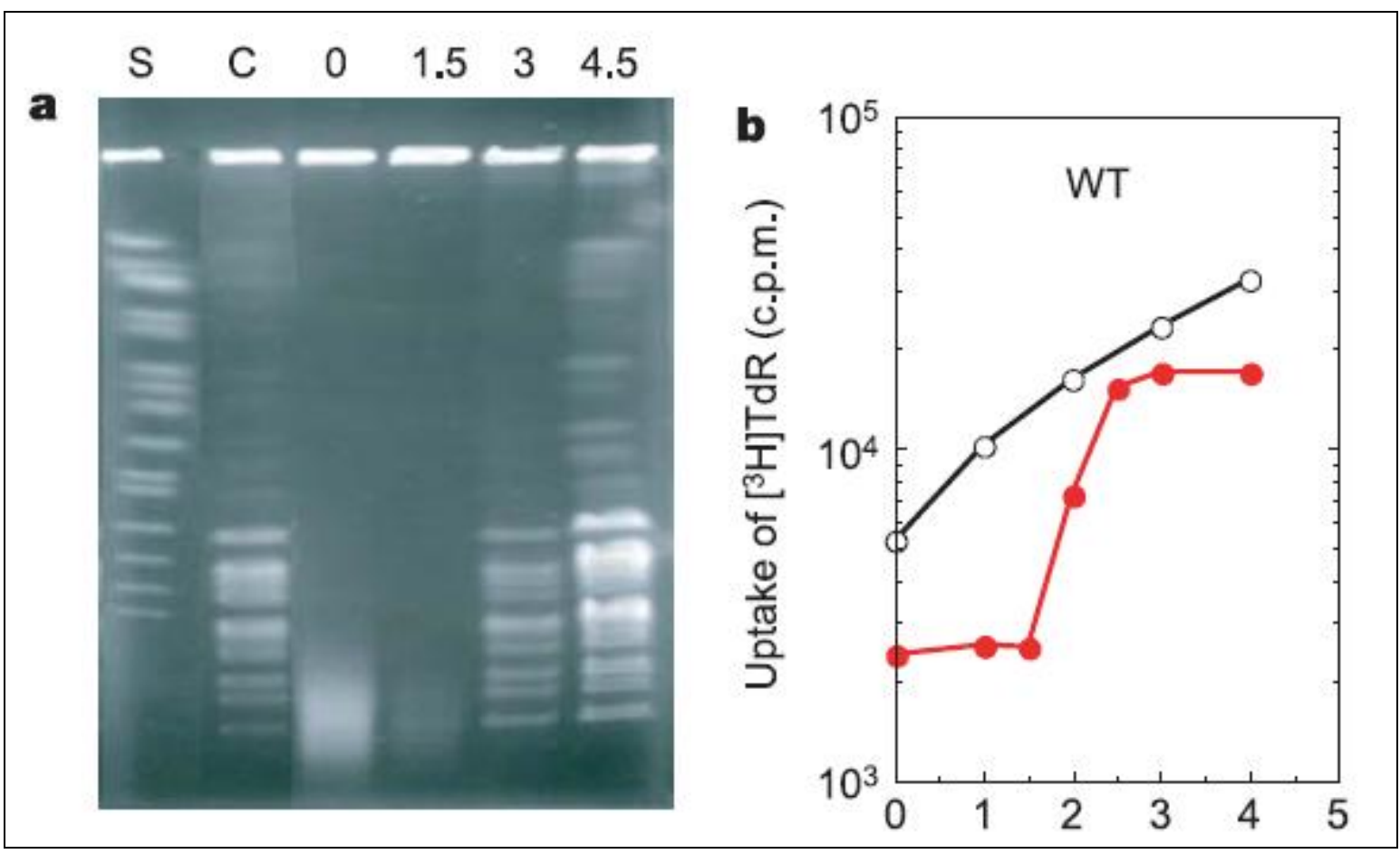

Figura 29: a) Gel de Eletroforese de campo pulsado de: $\mathrm{S}$ - a levedura $S$. cerevisiae, $\mathrm{C}-\mathrm{a}$ bactéria $D$. radiodurans não irradiado, $0 ; 1,5 \mathrm{~h} ; 3 \mathrm{~h}$ e $4,5 \mathrm{~h}$ após a irradiação com gamas a 7kGy. b) Gráfico: o eixo y representa o tamanho dos fragmentos de DNA de $D$. radiodurans e o eixo horizontal representa o tempo de exposição após a irradiação com gamas a $7 \mathrm{kG}$. Curva em preto representa 0 tamanho dos fragmentos de DNA de $D$. radiodurans sem irradiação e a curva em vermelho representa o tamanho dos fragmentos de DNA de $D$. radiodurans irradiada com gamas a 7kGy.

Fonte: Zahradka, 2006.

Explorar os mecanismos de resistência da $D$. radiodurans pode inspirar estudos em oncologia, além de poder ser visualizada como um modelo bacteriano, para neurônios indivisíveis e de vida longa, de grande relevância para abordagens anti-envelhecimento $e$ investigações em medicina regenerativa (ZAHRADKA, 2006).

\subsubsection{Irradiação com Gamas e Exposição ao Campo Magnético}

Continuamos as irradiações da $D$. radiodurans com gamas em doses entre 0 e 8 kGy, seguindo-se de exposição a um campo magnético (CM) de intensidade 0,4 Tesla por $10 \mathrm{~h}$ ininterruptamente. 
As figuras 30 e 31 apresentam as curvas de sobrevivência das fases exponencial e estacionária obtidas. Observa-se na inserção da figura 30 que 0 ombro de reparo manifestado na fase exponencial foi de 4 kGy e na inserção 2 da figura 31 o ombro de reparo foi de 6 kGy.

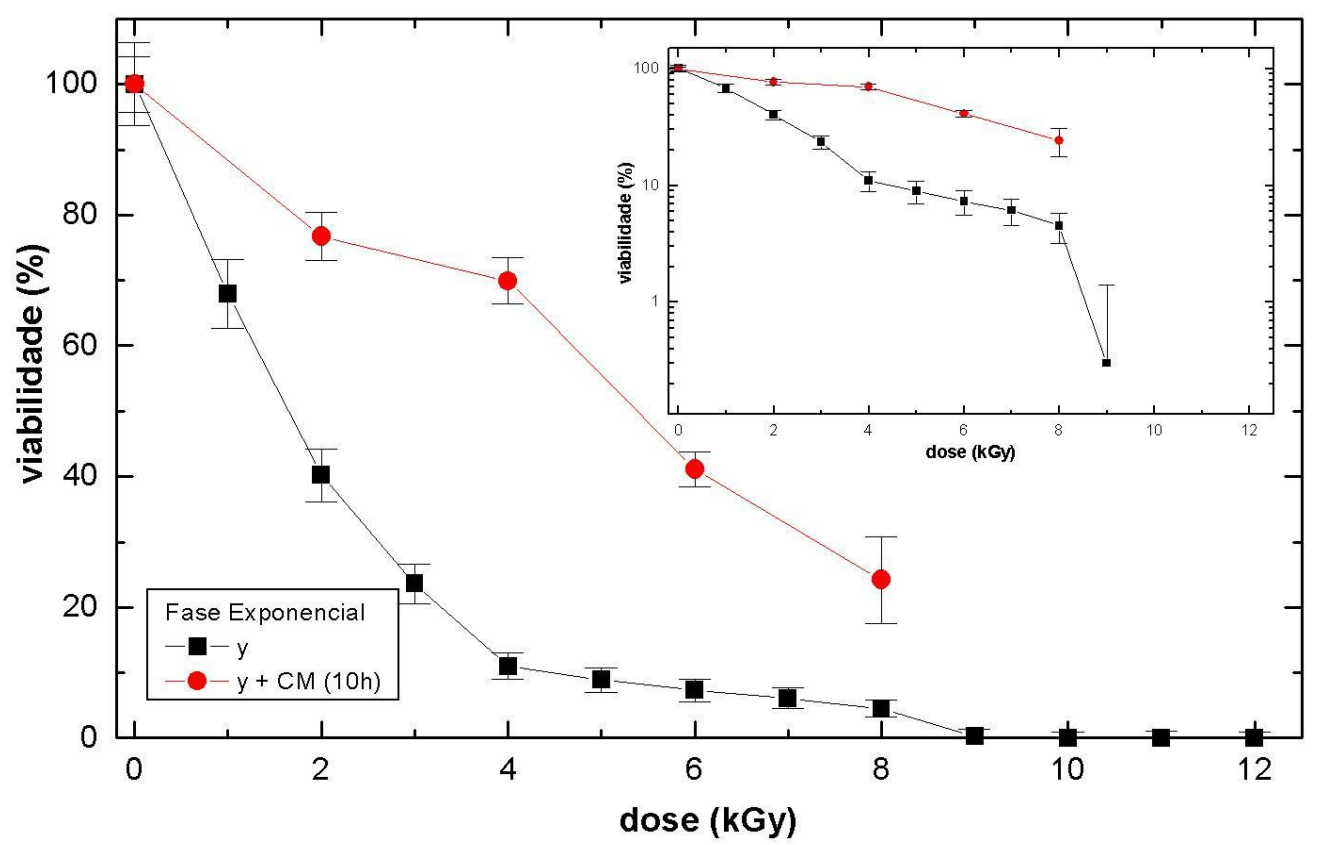

Figura 30: Curvas de sobrevivência da $D$. radiodurans na fase exponencial, sob a ação de radiação gama e radiação gama combinada com campo magnético por $10 \mathrm{~h}$. Inserção: Curvas de sobrevivência da $D$. radiodurans nas fases exponencial, sob a ação de radiação gama e radiação gama + campo magnético de $10 \mathrm{~h}$, escala linear-log. 


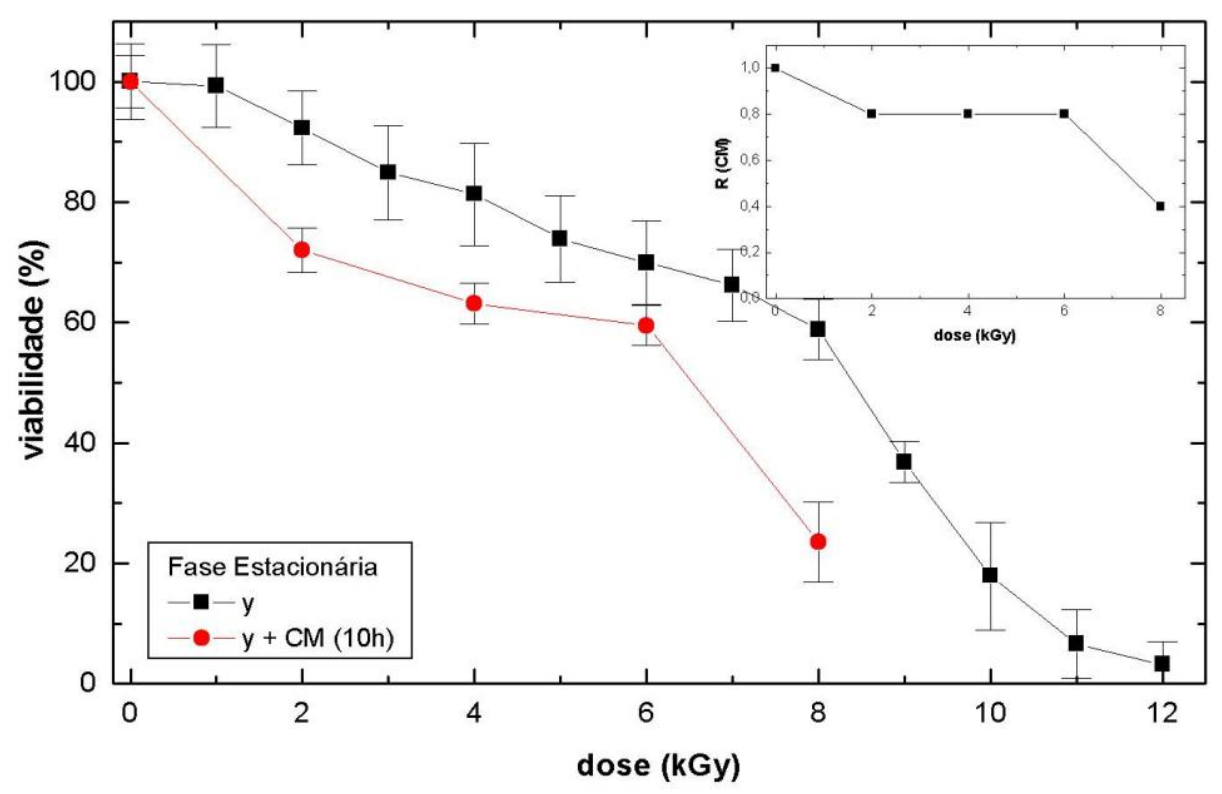

Figura 31: Curvas de sobrevivência da $D$. radiodurans na fase estacionária, sob a ação de radiação gama e radiação gama combinada com campo magnético de $10 \mathrm{~h}$. Inserção: Gráfico Relativo $(\mathrm{y}+\mathrm{CM} / \mathrm{\gamma})$ da $D$. radiodurans na fase estacionária, sob a ação radiação gama combinada com campo magnético de $10 \mathrm{~h}$.

A figura 31 apresenta os resultados na fase estacionária. $\mathrm{Na}$ inserção temos a razão entre as duas curvas de sobrevivência: $R=S(y+C M) / S(y)$, em que $S(\gamma+C M)$ e $S(\gamma)$ representam às viabilidades celulares correspondentes a irradiação com e sem exposição ao campo magnético, respectivamente.

Chama-nos também a atenção o fato de que a ação citotóxica do $\mathrm{CM}$ na fase estacionária provocou redução do ombro de 8 kGy para 6 kGy $(25 \%$ de redução), comparativamente menor à redução provocada pelo CE, de 8 kGy para 4 kGy (50\% de redução).

Em 8 kGy, por exemplo, temos $R \approx 0,4$, ou seja, o CM foi responsável por uma perda adicional de viabilidade de aproximadamente $60 \%$ nessa dose (tabela 13), uma redução menor do que a provocada pelo CE nesta mesma dose $(R \approx 0,4,-80 \%)$. 
Tabela 13 - Taxa entre as duas curvas de sobrevivência (figura 31 - inserção).

\begin{tabular}{c|c|c|c|c|c}
\cline { 2 - 6 } & \multicolumn{5}{c}{ Gráfico Relativo: $\gamma+\mathbf{C M} / \gamma$} \\
\hline Dose (kGy) & $\mathbf{0}$ & $\mathbf{2}$ & $\mathbf{4}$ & $\mathbf{6}$ & $\mathbf{8}$ \\
\hline Fase Estacionária & 1,00 & 0,77 & 0,77 & 0,83 & 0,40 \\
\hline
\end{tabular}

Esta circunstância é notadamente interessante se pensarmos em aplicações radioterápicas associadas a CM, pois a disponibilidade de campos magnéticos intensos é rotineira na área médica de imageologia (por exemplo, em Ressonância Magnética Nuclear).

\subsubsection{Proposição de um modelo Biofísico para $y+$ CM}

$\mathrm{Na}$ figura 32 propomos um outro modelo biofísico, desta vez para o comportamento dos fragmentos de DNA de $D$. radiodurans sob a ação de CM após irradiação. Os fragmentos sem ação do $\mathrm{CM}$ se reconectam por homologia (Figura 32-A). Contudo, a ação do CM produz uma força magnética. Esta força magnética provoca um binário de forças nos dipolos elétricos dos fragmentos. Assim, os fragmentos tendem a girar (figura 32-B), aumentando a homologia, e consequentemente a sobrevivência. $O$ aumento do ombro de reparo da $D$. radiodurans as exposições ao $\mathrm{CM}$ em ambas às fases comprova este raciocínio. 

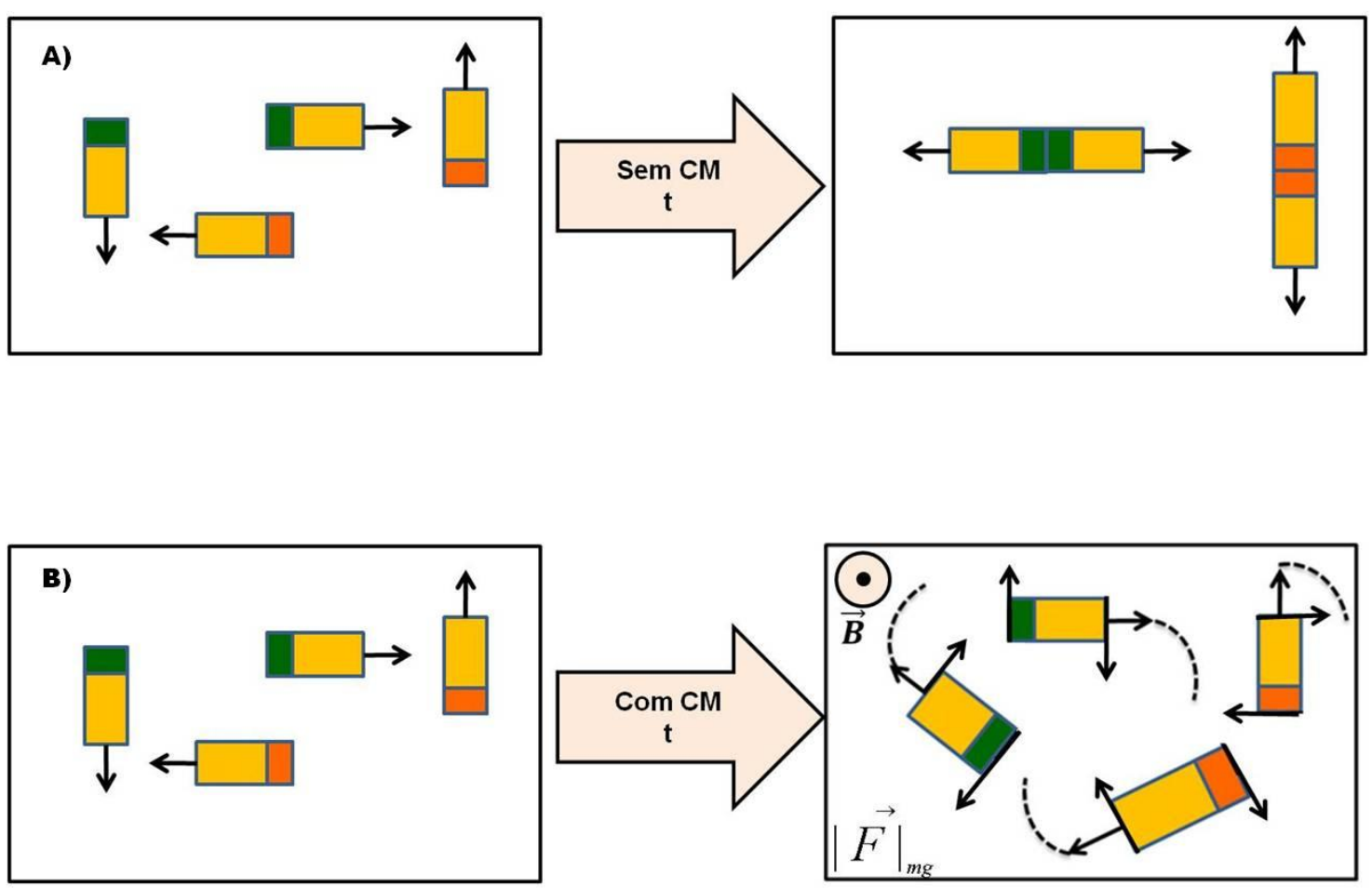

Figura 32: Esquema ilustrativo do modelo biofísico da ação do CM aos fragmentos de DNA.

\subsubsection{Irradiações com Feixes de Elétrons}

Nas irradiações com gamas, reproduzimos a radioresistência da $D$. radiodurans citada na literatura. $\mathrm{Na}$ investigação com outro tipo de radiação optamos por elétrons, pois a fonte disponível, um acelerador de elétrons, permite alcançar altas taxas de dose, o que não é possível com a fonte de gamas. Além disso, nunca foi realizado um ensaio de $D$. radiodurans com feixes de elétrons. Decorrente, possivelmente da necessidade em se dispor de um acelerador de elétrons, equipamento de operação e cuidados muito mais complexos do que uma fonte de Cobalto (gamas), e em geral de difícil acesso para grupos de pesquisas biológicas.

A figura 33 mostra as curvas de sobrevivência da $D$. radiodurans exposta a feixes de elétrons nas fases exponencial e estacionária. Mais uma vez, a fase exponencial foi mais sensível do que a fase estacionária. A inserção mostra a ação efetiva das irradiações com elétrons. O ombro de reparo foi completamente eliminando na fase exponencial e de apenas 1 kGy na 
estacionária.

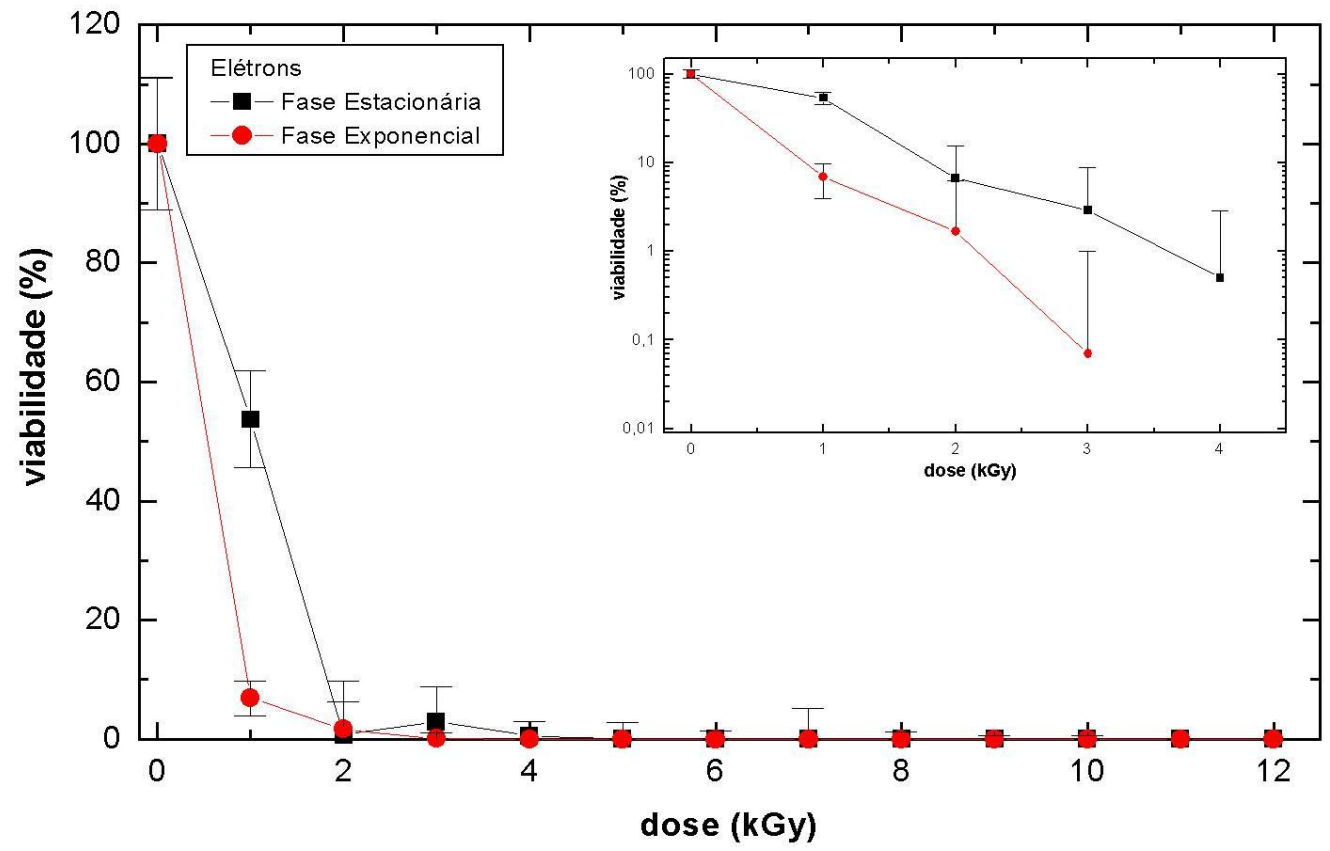

Figura 33: Curvas de sobrevivência da $D$. radiodurans na fase exponencial e estacionária, sob a ação de elétrons. Inserção: Curvas de sobrevivência da $D$. radiodurans na fase exponencial e estacionária, sob a ação de elétrons, escala linear-log.

As figuras 34 e 35 mostram a $D$. radiodurans expostas a gamas e elétrons e gamas nas fases exponencial e estacionária. Estes resultados deixam clara a ação efetiva das irradiações com elétrons em relação a gamas.

Podemos observar na inserção da figura 34 que o ombro de reparo na fase exponencial foi completamente eliminado com elétrons e de apenas 2 kGy com gamas. 


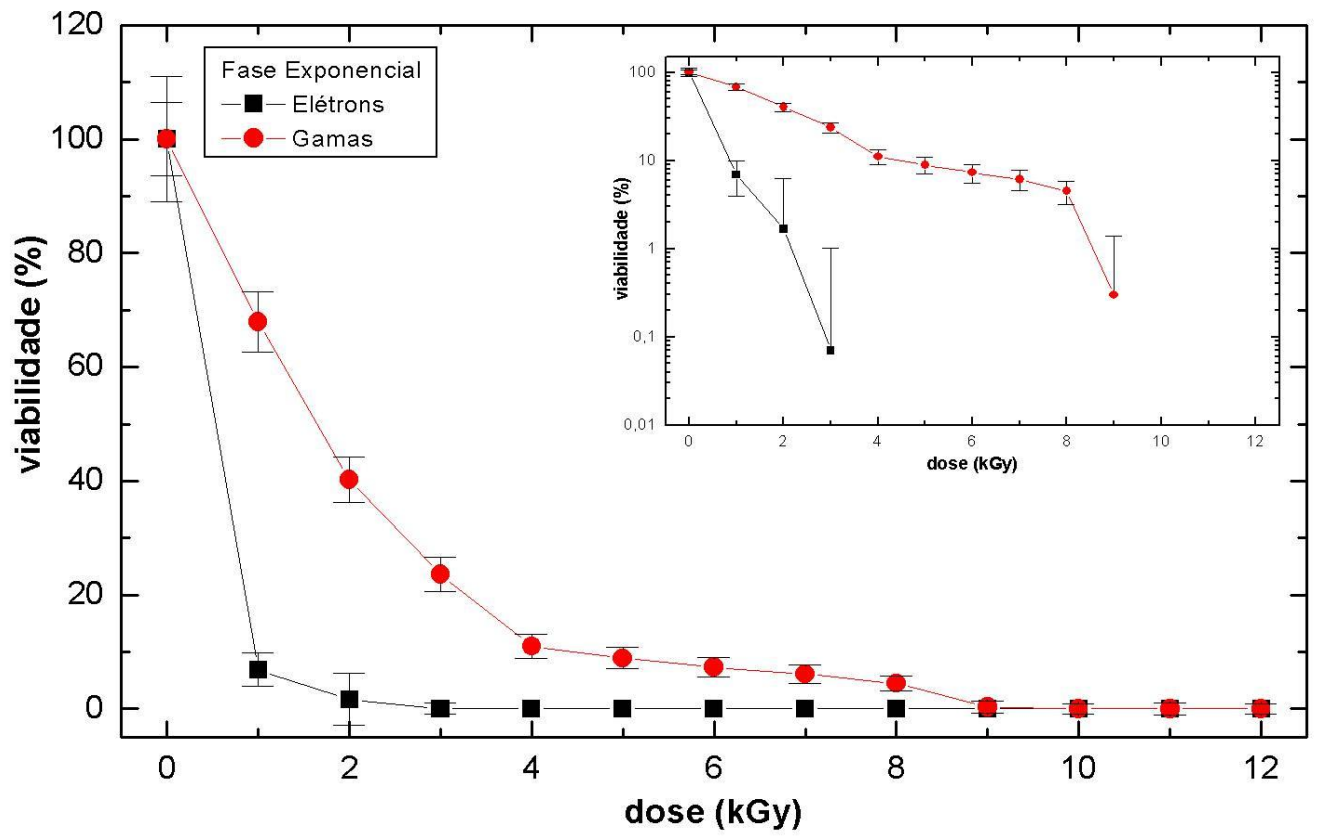

Figura 34: Curvas de sobrevivência da $D$. radiodurans na fase exponencial, sob a ação de gama e elétrons. Inserção: Curvas de sobrevivência da $D$. radiodurans na fase exponencial, sob a ação gama e elétrons, escala linear-log.

$\mathrm{Na}$ inserção da figura 35 observa-se melhor que a fase estacionária apresenta um ombro menor do que $1 \mathrm{kGy}$ com elétrons, enquanto que com gamas foi de 8 kGy. 


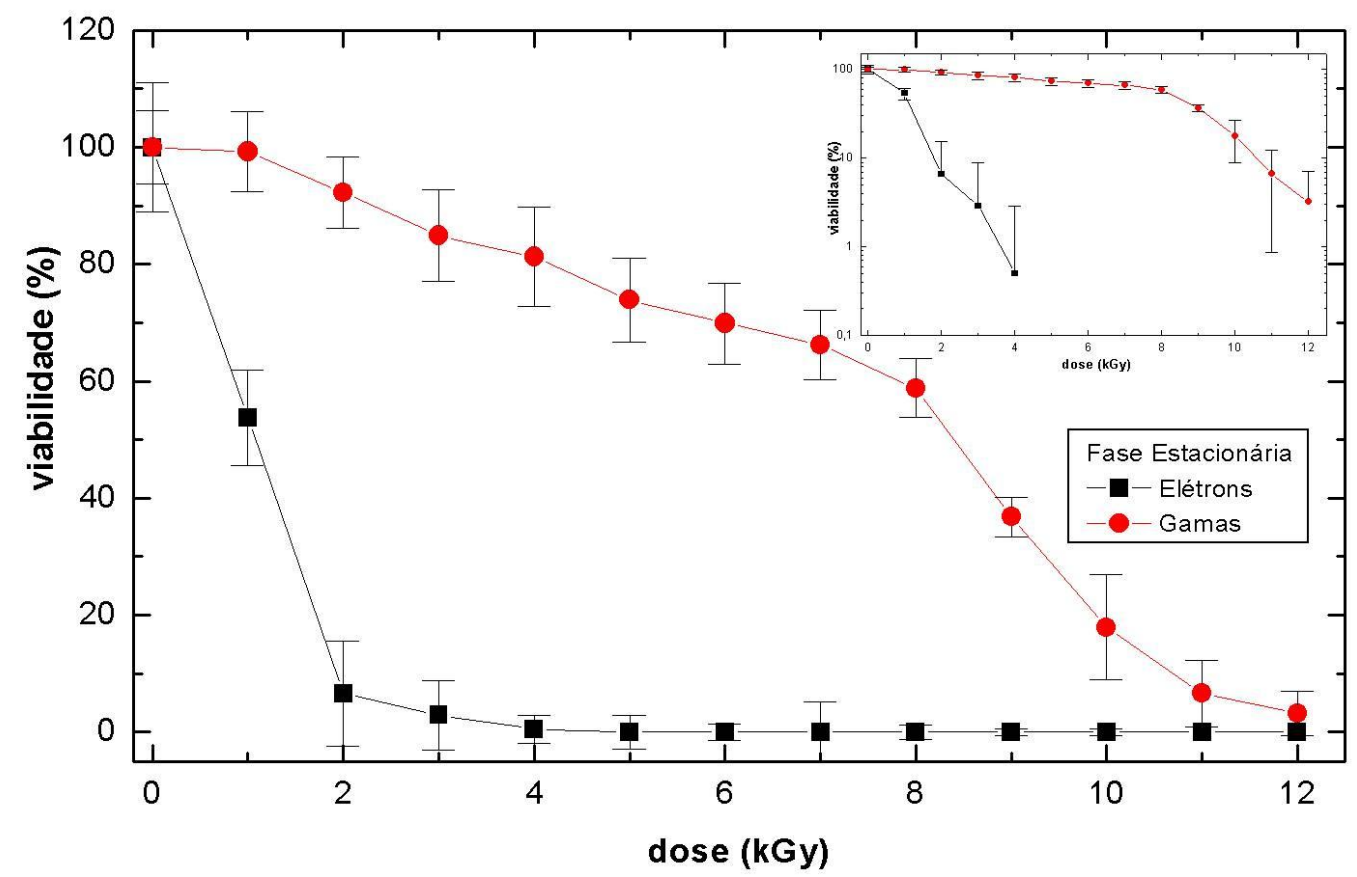

Figura 35: Curvas de sobrevivência da $D$. radiodurans na fase estacionária, sob a ação de gama e elétrons. Inserção: Curvas de sobrevivência da $D$. radiodurans na fase estacionária, sob a ação gama e elétrons, escala linear-log.

Também pudemos observar que a $D$. radiodurans apresentou ser muito sensível a exposição de elétrons com taxas de dose como as utilizadas em nosso estudo. Com apenas $1 \mathrm{kGy}$ ocorreram mortes superiores a 50 e $90 \%$ nas fases estacionária e exponencial, respectivamente.

O dano biológico está relacionado com a quantidade de ionizações produzidas pela radiação no meio. Na passagem da radiação por um material, parte da energia se consome nas ionizações dos átomos que liberam elétrons com determinada energia cinética. A energia depositada é proporcional ao número de ionizações, e, portanto o dano biológico produzido fica diretamente relacionado com a dose. Radiações como gamas são considerados de baixo LET, ou, pouco ionizantes. Por outro lado, elétrons de baixa energia (entre $1 \mathrm{e}$ $2 \mathrm{MeV}$ ) apresentam LETs similares aos da radiação gama, mas por possuírem carga elétrica produzem maior quantidade dos denominados "elétrons inesperados" - são elétrons secundários gerados por um processo de autoionização ainda pouco conhecido e denominado Decaimento Coulômbico 
Intermolecular (TILMANN e PAUL, 2010). São produzidos cerca de $5 \times 10^{4}$ desses elétrons por $\mathrm{MeV}$ de energia transferida pela radiação. Dessa forma, 0 genoma da $D$. radiodurans seria intensamente "iluminado" em toda a sua extensão, produzindo maior fragmentação comparativamente à que seria produzida com a radiação gama (radiação com menor poder de frenagem stopping power). Essa circunstância foi verificada experimentalmente em irradiações de plasmídeos conforme comentado mais abaixo (figuras 37 e 38).

Os resultados com elétrons mostram que com apenas $2 \mathrm{kGy}$ tínhamos eliminado toda a população e praticamente com ausência de ombro de reparo. Portanto, qualquer exposição adicional a agentes citotóxicos seria irrelevante, razão pela qual deixamos de submeter às amostras de $D$. radiodurans aos campos elétrico e magnético. Os elétrons utilizados em altíssimas taxas de doses comportaram-se como uma radiação de alto LET, fato que não ocorre em taxas de doses moderadas. Essa constatação abre perspectiva para a possibilidade de se aumentar o LET das irradiações manipulando-se apenas as taxas de dose, sem a necessidade de recorrer-se a radiações de difícil manipulação (nêutrons e alfas, por exemplo).

A figura 36 apresenta a E. coli submetida a elétrons. A radiossensibilidade da $E$. coli para elétrons é maior que para gamas. Devido à grande radiossensibilidade, sua curva de sobrevivência não se estende acima de 3,5 kGy e não apresenta ombro de reparo (inserção da figura 36). Observamos também que com apenas 0,5 kGy houve uma queda de aproximadamente $100 \%$ da viabilidade celular. A resposta da $E$. coli a elétrons nas fases exponencial e estacionária é muito similar. 


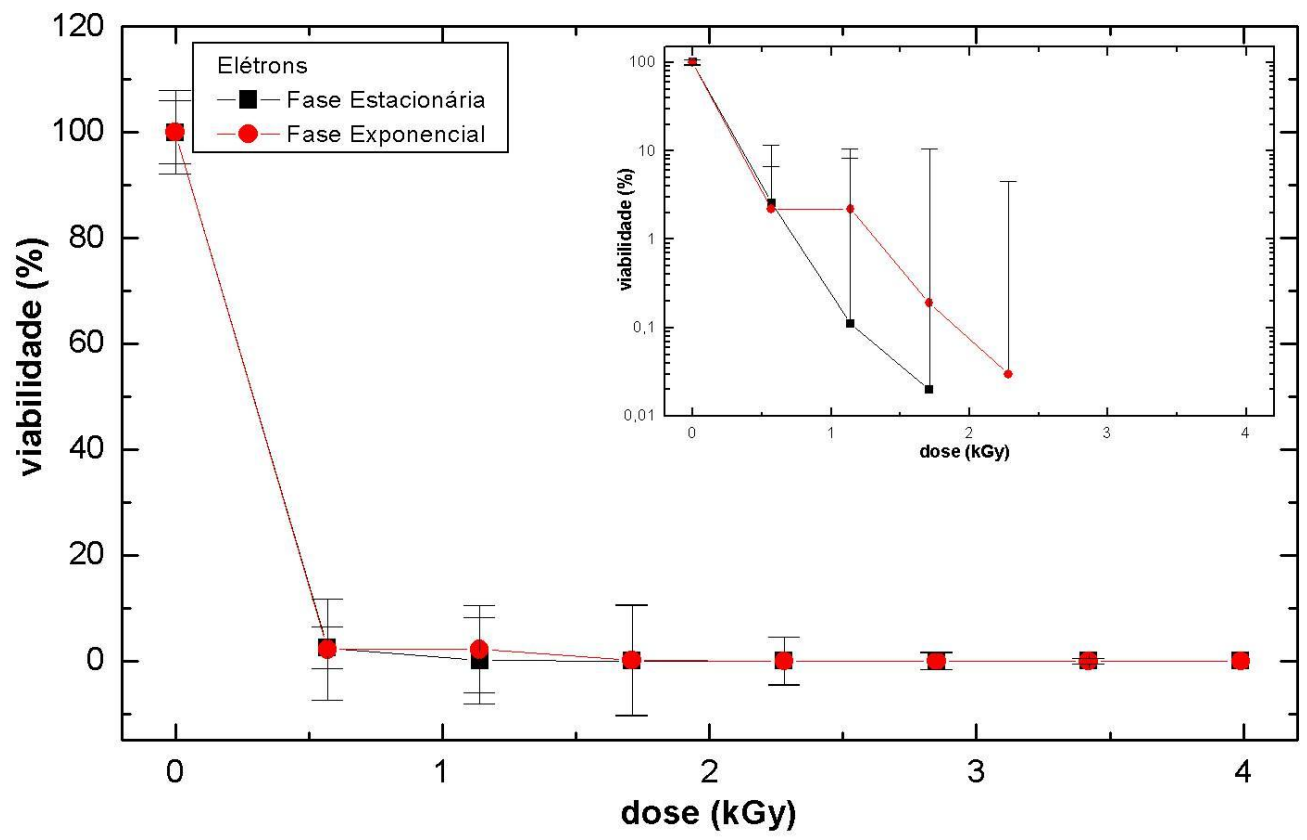

Figura 36: Curvas de sobrevivência de E. coli nas fases exponencial e estacionária sob ação combinada de elétrons. Inserção: Curvas de sobrevivência da $E$. coli nas fases exponencial e estacionária, sob a ação de elétrons, escala linear-log.

\subsubsection{Avaliação do Efeito de Altas Doses}

Para atingir uma dose de 2 kGy com gamas, foi necessário a exposição das amostras por $50 \mathrm{~min}$. A fonte de Cobalto-60, utilizada nesse estudo, eleva de forma lenta e contínua a energia depositada em cada amostra até atingir a dose de interesse.

Nas irradiações com elétrons foi necessário apenas 4 min para atingir a mesma dose. As amostras receberam uma dose de 0,5 kGy a cada passada e em $0,223 \mathrm{~s}$ toda essa energia foi depositada de uma só vez (item 3.19, tabela 10). A taxa de dose "média" com elétrons é aproximadamente 13 vezes maior do que para gamas, ou seja, cerca de $26 \mathrm{kGy} / \mathrm{h}$. Contudo, a taxa de dose "instantânea" é altíssima, maior do que $8 \times 10^{3} \mathrm{kGy} / \mathrm{h}$, quase 3 ordens de grandeza superior à de gamas. 
Os resultados obtidos com elétrons são, a nosso ver, muito importantes tanto do ponto de vista acadêmico quanto radiobiológico. $\mathrm{O}$ fato da taxa de dose com elétrons ser muito maior do que para gamas deve afetar grandemente o desempenho de reparo, ou seja, o timing do pool de proteínas de reparo da $D$. radiodurans. Assim, o "timing" do "pool" pode não ser suficiente para reparar uma produção tão elevada de danos ao DNA num espaço de tempo tão curto.

Também, a taxa de dose "instantânea" $\left(8 \times 10^{3} \mathrm{kGy} / \mathrm{h}\right.$, quase 3 ordens de grandeza superior à de gamas) poderia ser um fator determinante na diminuição da capacidade de reparo da $D$. radiodurans.

Evidências desse fato foram obtidas em outro estudo de nosso grupo (NIETO, 2011). O DNA plasmidial pBS foi irradiado com gamas e elétrons (os mesmos deste trabalho), e a distribuição de fragmentos foi determinada por AFS (Atomic Force Spectrometry - Microscopia de Força Atômica). Os resultados são mostrados nas figuras 37 e 38 para gamas e elétrons, respectivamente.

Na figura 37, a escala horizontal indica a posição dos pares de bases e, ao mesmo tempo, as medidas dos comprimentos dos fragmentos. Como pode se observar, a sobreposição destes dois conjuntos de dados é bastante evidente. É surpreendente e revelador o fato de que com gamas obtém-se uma distribuição "discreta" para os tamanhos dos fragmentos, enquanto que com elétrons (figura 38) o DNA plasmidial foi "picotado". Caso isso também ocorra com o DNA celular teríamos uma explicação para a total perda de viabilidade de $D$. radiodurans quando irradiada com elétrons. 


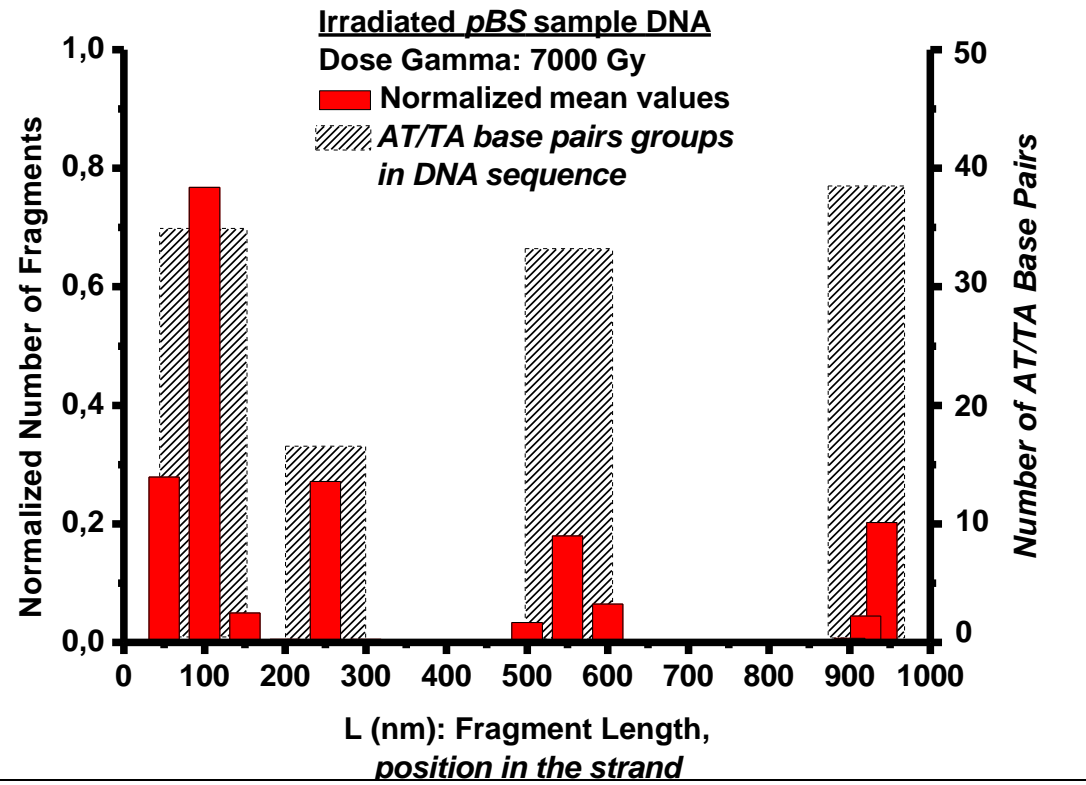

Figura 37: Distribuição de fragmentos de DNA por AFS a uma dose de 7kGy. Fonte: Gonzalez, 2011.

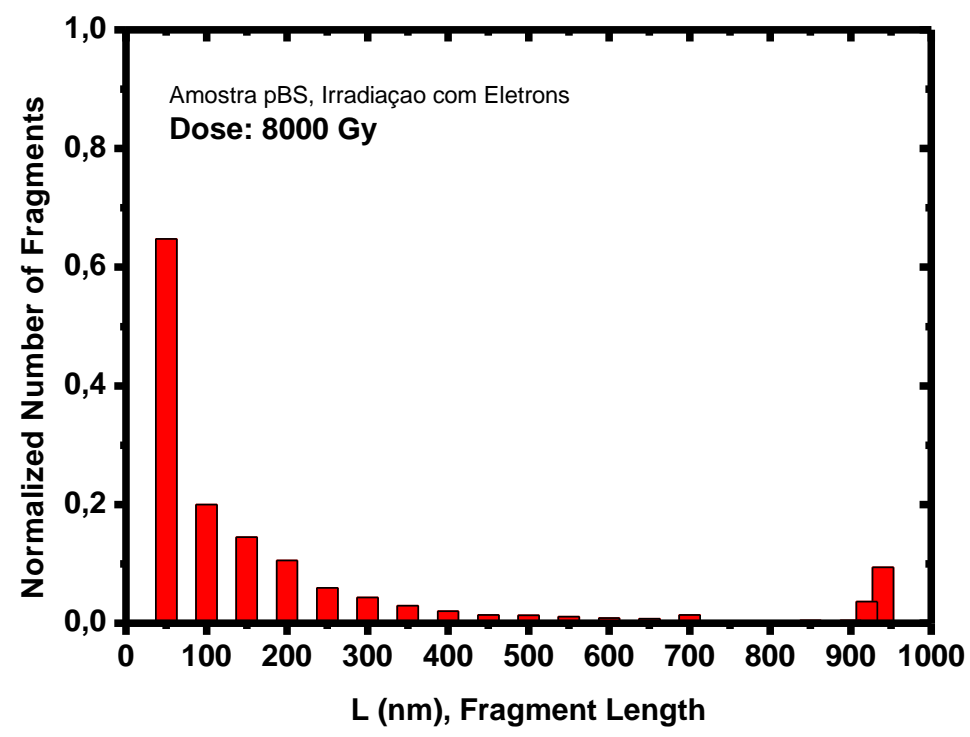

Figura 38: Distribuição de fragmentos de DNA por AFS a uma dose de 8kGy. Fonte: Gonzalez, 2011.

Este trabalho constitui a primeira tentativa de estudo da radioresistência e sensibilidade da $D$. radiodurans a exposições a feixes de elétrons e a associação de radiação gama a campos elétrico ou magnético exógenos. 
5 Conclusões 
1 A $D$. radiodurans apresentou radioresistência similar em ambas as fases de crescimento quando o número de células inicial foi ajustado.

2 A associação de radiação gama com exposição a campo elétrico reduziu o ombro de reparo de $D$. radiodurans em ambas as fases, demonstrando que essa combinação de estresses em muito aumenta sua radiossensibilidade. Efeito similar, mas em menor intensidade, também foi observado com exposição a campo magnético e apenas na fase estacionária. A regeneração provocada pelo campo magnético na fase exponencial merece um estudo mais aprofundado e provavelmente expirará muitas aplicações.

3 O estudo de $D$. radiodurans submetida a elétrons foi realizado pela primeira vez. A radiossensibilidade observada foi surpreendentemente muito maior do que em irradiações com gamas. Um modelo biofísico tentativo é proposto.

4 Em possíveis aplicações radioterápicas as doses deverão ser "normalizadas" (para Grays e Centigrays). Contudo, as respostas qualitativas aos estresses (redução e perda de ombro de reparo) devem permanecer iguais.

5 Estudo dos processos de reparação em $D$. radiodurans quando exposta a radiações muito ionizantes como feixes de prótons e alfas, de grande relevância para a emergente técnica de hádron terapia de câncer.

6 Utilização nesses estudos de técnicas moleculares, como por exemplo, a observação direta da síntese dos fragmentos via AFM, preferencialmente.

7 Condução de estudos similares com outros microrganismos 
radioresistentes como as bactérias $R$. xylanophilus e $R$. radiotolerans. 
Referências 


\section{REFERÊNCIAS ${ }^{1}$}

AHBOM, A.; DAY, N.; FEYHTING, M.; ROMAN, E.; SKINNER, J.; DOCKERTY, J.; LINET, M.; MCBRIDE, M.; MICHAELIS, J.; OLSEN, J. H.; TYNES, T.; VERKASALO, P. K. A pooled analysis of magnetic fields and childhood leukaemia. Brit. J. Cancer, v. 83, p. 692-698, 2000.

ANDERSON, A. W.; NORDAN, H. C.; CAIN, R. F.; PARRISH, G.; DUGGAN, D. Studies on a radio-resistant micrococcus. I. isolation, morphology, cultural characteristics, and resistance to gamma radiation. Food Technology, v. 10, p. 575-578, 1956.

ARRUDA-NETO, J. D. T. et al. Static electric fields interfere in the viability of cells exposed to ionizing radiation. Int. J. Radiat. Biol., v. 85, n. 4, p. 314-321, Apr. 2009.

ARRUDA-NETO, J. D. T. et al. Developing new radiotherapy techniques using Linac based gamma radiation sources. Proceedings of the 8th International Topical Meeting on Nuclear Applications and Utilization of Accelerators. American Nuclear Society, p. 398-404, 2009.

ARRUDA-NETO, J. D. T. et al., The role played by endogenous and exogenous electric fields in DNA signaling and repair. DNA Repair, v. 9, p. 356-357, 2010.

ARRUDA-NETO, J. D. T.; BITTENCOURT-OLIVEIRA, M. C.; FRIEDBERG, E. C.; SILVA, E. C.; SCHENBERG, A. C. G.; OLIVEIRA, M. C. C.; HEREMAN, T. C.; MESA, J.; RODRIGUES, T. E. ; SHTEJER, K.; GARCIA, C.; GARCIA, F.; LOUVISON, M.; PAULA, C. R. Electric Field Interference in DNA repair: Model Approach and Case Studies, v. 02, p. 2, Radiat. Res, 2010.

BATTISTA, J. R. Against All Odds: The Survival Strategies of Deinococcus radiodurans (Review). Annu. Rev. Microbiol., v. 51, p. 203-224, 1997.

BATTISTA, J. R.; EARL, A. M.; PARK, M. J. Why is Deinococcus radiodurans so resistant to ionizing radiation? Trends Microbiol., v. 7, p. 362-365, 1999.

BATTISTA, J. R.; PARK, M. J.; MCLEMORE, A. E. Inactivation of two homologues of proteins presumed to be involved in the desiccation tolerance of plants sensitizes Deinococcus radiodurans R1 to desiccation. Cryobiology, v. 43, n. 2, p. 133-139, 2001.

BATTISTA, J. R.; COX, M. M. Deinococcus radiodurans - the consummate survivor. Nature, v. 3, p. 882-892, Nov. 2005.

1 De acordo com: ASSOCIAÇÃO BRASILEIRA DE NORMAS TÉCNICAS. NBR 6023: informação e documentação: referências: elaboração. Rio de Janeiro, 2002. 
BELLI, M.; SAPORA, O.; TABOCCHINI, M. A. Molecular Targets in Cellular Response to lonizing Radiation and Implications in Space Radiation Protection. J. Radiat. Res., v. 43, p. 13-19, 2002.

BIRAL, A. R. Radiações ionizantes para médicos, físicos e leigos. São Paulo: Editora Insular, 2002.

BRASIL. Ministério da Saúde. Secretaria de Atenção à Saúde. Instituto Nacional do Câncer. Coordenação de Prevenção e Vigilância. Estimativas 2010: Incidência de câncer no Brasil. Rio de Janeiro: INCA, 2010. Disponível em: <http://www.inca.gov.br/estimativa/2010> Acesso em: 22 dez. 2010.

CAMERON, I. L.; SUN, LU-ZHE; SHORT, N.; HARDMAN, W. E.; WILLIAMS, C. D. Therapeutic electromagnetic fields (TEMF) and gamma irradiation on human breast cancer xenograft growth, angiogenesis and metastasis. Cancer Cell Int., v. 5, p. 1-23, 2005.

D'HONDT, S.; JORGENSEN, B. B.; MILLER, D. J.; BATZKE, A.; BLAKE, R.; CRAGG, B. A.; CYPIONKA, H.; DICKENS, G. R.; FERDELMAN, T.; HINRICHS, K. U.; HOLM, N. G.; MITTERER, R.; SPIVACK, A.; WANG, G. Z.; BEKINS, B.; ENGELEN, B.; FORD, K.; GETTEMY, G.; RUTHERFORD, S.; D. SASS, H.; SKILBECK, C. G.; AIELLO, I. W.; GUERIN, G.; HOUSE, C. H.; INAGAKI, F.; MEISTER, P.; NAEHR, T.; NIITSUMA, S.; PARKES, R. J.; SCHIPPERS, A.; SMITH, D. C.; TESKE, A.; WIEGEL, J.; PADILLA, C. N.; ACOSTA, J. L. S. Distributions of microbial activities in deep subseafloor sediments. Science, v. 306, n. 5705, p. 2216-2221, 2004.

DALY, M. J. LING, O. Y. FUCHS, P. MINTON, K. W. In-vivo damage and RecADependent Repair of plasmid and chromosomal DNA in the radiation-resistant bacterium Deinococcus radiodurans. Journal of Bacteriology, v. 176, n. 12, p. 3508-3517, Jun. 1994.

DALY, M. J. Engineering radiation-resistant bacteria for environmental biotechnology. Current Opinion in Biotechnology, v. 11, n. 3, p. 280-285, 2000.

DALY, M. J. GAIDAMAKOVA, E. K. MATROSOVA, V. Y. VASILENKO, A. ZHAI, $M$. VENKATESWARAN, A. HESS, M. OMELCHENKO, M. V. KOSTANDARITHES, H. M. MAKAROVA, K. S. WACKETT, L. P. FREDRICKSON, J. K. GHOSAL, D. Accumulation Of Mn(li) In, Deinococcus radiodurans facilitates gamma-radiation resistance. Science, v. 306, n. 5698, p. 1025-1028, 2004.

DEINHARD, G.; SAAR, J.; KRISCHKE, W.; PORALLA, K. Bacillus acidoterrestris sp. nov., a new thermotolerant isolated from different soils. Systematic Applied Microbiology, v. 10, n. 1, p. 47-53, Nov. 1987a.

FARIA, S. L.; LEME, L. H. S.; OLIVEIRA FILHO, J. A. Câncer de Mama: Diagnóstico e Tratamento. São Paulo: MEDSI, 1994. 
FERREIRA, A. C. et al. Characterization and radiation resistance of new isolates of Rubrobacter radiotolerans and Rubrobacter xylanophilus. Extremophiles, n. 3, p. 235-238, 1999.

FIECHETER, A.; KÄPPELI, O.; MEUSSDOERFFER, F. Batch and Continuous Culture. In: ROSE, A. H.; HARRISON, J. S. The Yeasts. 2nd ed. New York: Academic Press, 1987. v. 2, Cap. 5.

GELDOF, A. A. et al. Cell cycle perturbations and radiosensitization effects in a human prostate cancer cell line. J. Cancer Res. Clin. Oncol., v. 129, p. 175182, 2003.

GOODHEAD, D. T. Initial events in the cellular effects of ionizing radidtions: clustered damage in DNA. International Journal of Radiation Biology, v. 65, n. 1 , p. $7-17,1994$

DALY, M. J. How radiation kills cells: Survival of Deinococcus radiodurans and Shewanella oneidensis under oxidative stress. FEMS Microbiology Reviews, v. 29, n. 2, p. 361-375, 2005.

GREENLAND, S.; SHEPPARD, A. R.; KAUNE, W. T.; POOLE, C.; KELSH, M. A. A pooled analysis of magnetic fields, wire codes, and childhood leukemia. Epidemiology, v. 11, p. 624-634, 2000.

HALL, E. J. The Physics and Chemistry of Radiation Absorption. In:

Radiobiology for the Radiologist, $4^{\text {th }}$ ed. New York: J.B. Lippincott Company, 1994. Cap. 1.

HALL, E. J. Cell Survival Curves. In: Radiobiology for the Radiologist. 4th ed. New York: J.B. Lippincott Company, 1994. Cap. 3.

HE, Y. High cell density production of Deinococcus radiodurans under optimized conditions. Journal of Industrial Microbiology \& Biotechnology, v. 36, n. 4, p. 539-546, 2009.

HILL, M. A.; HERDMAN, M. T.; STEVENS, D. L.; JONES, N. J.; THAEKER J.; GOODHEAD, D. T. Relatives Sensitivities of Repair-Deficient Mammalian Cells for Clonogenic Survival after a-Particle Irradiation. Radiat. Res., v. 162, p. 667676, 2004.

HOBBIE, R. K. Intermediate Physics for Medicine and Biology. 3rd ed. New York: Springer-Verlag, 1997.

IMAMURA, M.; SAWADA, S.; KASAHARA-IMAMURA, M.; HARIMA, K.; HARADA, K. Synergistic cell-killing effect of a combination of hyperthermia and heavy ion beam irradiation: In expectation of a breakthough in the treatment of refractory cancers (Review). Int. J. Mol. Medicine, n. 9, p. 11-18, 2002.

JAY, I. M. Moderna Food Microbiology. 6th ed. New York: International Thomson Publishing, 2001. 
KAMIDA, A. et al. Effect of neutron capture therapy on the cell cycle of human squamous cell carcinoma cells. Int. J. Radiat. Biol.; v. 84, n. 3, p. 191-199, 2008.

KELLER, L. C.; MAXCY, R. B. Effect of physiological age on radiation resistance of some bacteria that are highly radiation resistant. Appl. Environ. Microb., v. 47, p. 915-918, 1984.

KERMANSHAHI, R. K.; SAILANI, M. R. Effect of static electric field treatment on multiple antibiotic-resitant pathogenic strains of Escherichia coli and Staphylococcus aureus. J. Microbiol. Immunol. Infect, v. 38, p. 394-398, 2005.

KIRSON, E.; GURVICH, Z.; SCHNEIDERMAN, R.; DEKEL, E.; ITZHAKI, A.; WASSERMAN, Y.; SCHATZBERGER, R.; PALTI, Y. Disruption of cancer cell replication by alternating electric fields. Cancer Res., v. 64, p. 3288-3295, 2004.

KIMURA, H.; ASADA, R.; MASTA, A.; NAGANUMA, T. Distribution of microorganisms in the subsurface of the manus basin hydrothermal vent field in Papua new guinea. Applied and Environmental Microbiology, v. 69, n. 1, p. 644-648, 2003.

KOPYLOV, V. M.; BONCHOSMOLOVSKAYA, E. A.; SVETLICHNYI, V. A.; MIROSHNICHENKO, M. L.; SKOBKIN, V. S. Gamma-irradiation resistance and UV-sensitivity of extremely thermophilic archebacteria and eubacteria. Microbiology, v. 62, n. 1, p. 63-67, 1993.

KOYAMA, S.; NAKAHARA, T.; SAKURAI, T.; KOMATSUBARA, Y.; ISOZUMI, Y.; MIYAKOSHI, J. Combined exposure of ELF magnetic fields and X-rays increased mutant yields compared with X-rays alone in pTN89 plasmids. J. Radiat. Res., v. 46, p. 257-262, 2005.

KUFE, D. W.; POLLOCK, R. E.; WEICHSELBAUM, R. R.; BAST, R. C. JR.; GANSLER, T. S.; HOLLAND, J. F.; FREI III, EMIL. Cancer Medicine. 6th ed. Canada: Hamilton, 2003. Cap. 17

LAMOSA, P.; SANTOS, H.; COSTA, M. S. Extremófilos: microrganismos à prova de agressões ambientais extremas. Biotecnologia Microbiana, n. 69, p. 2-10, ago. 2001.

LI, J.; HUANG, S.; ARMSTRONG, E. A.; FOWLER, J. F.; HARARI, P. M. Angiogenesis and Radiation response modulation after vascular endothelial growth factor receptor-2 (VEGFR2) blockade. Int. J. Radiat. Oncol. Biol. Phys., v. 62, p. 1477-1485, 2005.

LOUVISON, M. Efeitos da irradiação gama, e de campos elétricos e magnéticos sobre o crescimento, viabilidade, morfologia e produção de exoenzimas em Candida albicans. 2007. 86 f. Dissertação (Mestrado em Biotecnologia) - Instituto de Ciências Biomédicas, Universidade de São Paulo, 
São Paulo, 2007.

MADIGAN, B.; MICHAEL, T.; MARTINKO, J. M.; PARKER, J. Microbiologia de Brock. São Paulo: Prentice Hall, 2004.

MAHRHOFER, H.; BÜRGER, S.; OPPITZ, U.; FLENTJE, M.; DJUZENOVA C. $S$. Radiation induced DNA damage and damage repair in human tumor and fibroblast cell lines assessed by histone H2AX phosphorylation. Int. J. Radiat. Oncol. Biol. Phys., v. 64, p. 573- 580, 2006.

MAKAROVA, K. S.; ARAVIND, L.; WOLF, Y. I.; TATUSOV, R. L.; MINTON, K. W.; KOONIN, E. V.; DALY, M. J. Genome of the extremely radiation-resistant bacterium Deinococcus radiodurans viewed from the perspective of comparative genomics. Microbiology and Molecular Biology Reviews, v. 65, n. 1, p. 44-79, 2001.

MAKAROVA, K. S.; OMELCHENKO, M. V.; GAIDAMAKOVA, E. K.; MATROSOVA, V. Y.; VASILENKO, A.; ZHAI, M.; LAPIDUS, A.; COPELAND, A.; KIM, E.; LAND, M.; MAVROMATIS, K.; PITLUCK, S.; RICHARDSON, P. M.; DETTER, C.; BRETTIN, T.; SAUNDERS, E.; LAI, B.; RAVEL, B.; KEMNER, K. M.; WOLF, Y. I.; SOROKIN, A.; GERASIMOVA, A. V.; GELFAND, M. S.; FREDRICKSON, J. K.; KOONIN, E. V.; DALY, M. J. Deinococcus geothermalis: The pool of extreme radiation resistance genes shrinks. Plos One, v. 2, n. 9, p. 1-12, 2007.

MATTIMORE, V.; BATTISTA, J. R. Radioresistance of Deinococcus radiodurans: Functions necessary to survive ionizing radiation are also necessary to survive prolonged desiccation. Journal of Bacteriology, v. 178, n. 3, p. 633-637, 1996.

MCBRIDE, W. H.; WITHERS, H. R. Biologic basis of radiation therapy. In: PEREZ, C. A. et al. Principles and pratice of radiation oncology. 4th ed. Philadelphia: Lippincott Williams \& Wilkins, 2004.

MILIAN, F. M. Estudo in vitro dos efeitos radiobiológicos no DNA plamidial com radiações ionizantes de baixo LET. 2006. $158 \mathrm{f}$. Tese (Doutorado em Física) - Instituto de Física, Universidade de São Paulo, São Paulo, 2006.

MILLER, J. H. A Short Course in Bacterial Genetics. A Laboratory Manual and Handbook for Escherichia coli and Related Bacteria. New York: Cold Spring Harbor Laboratory Press, 1992.

MIYAKOSHI, J.; YOSHIDA, M.; SHIBUYA, K.; HIRAOKA, M. Exposure to strong magnetic fields at power frequency potentiates $\mathrm{X}$-rays-induced DNA strand breaks. J. Radiat. Res., v. 41, p. 293-302, 2000.

MORON, M. M. Efeito da ação combinada de radiação gama e campo elétricoestático em células humanas. 2008. 98 f. Dissertação (Mestrado em Biotecnologia) - Instituto de Ciências Biomédicas, Universidade de São Paulo, 
São Paulo, 2008.

NAIR, C. K. K.; PARIDA, D. K.; NOMURA, T. Radioprotectors in Radiotherapy. J. Radiat. Res., v. 42, p. 21-37, 2001.

NIETO, L.; ARRUDA-NETO J. D. T.; COTTA, M. A.; CARRER, H.; GARCIA, F.; SILVA, R. A. S.; MOREAU, L. D.; RIGHI, H.. Study of DNA fragmentation by gamma radiation and electron beams using Atomic Force Microscopy. Journal of Biophysics Biology, 2011. In press.

NIKJOO, H.; O'NEILL, P.; TERRISSOL, M.; GOODHEAD, D. T. Modelling of radiationinduced DNA damage: the early physical and chemical event. Int. J. Radiat. Biol., v. 66, p. 453-457, 1994.

OKUNO, Emico et al. Física para Ciências Biológicas e Biomédicas. São Paulo: Harper \& Row Brasil, 1982.

OKUNO, Emico et al. Radiação: Efeitos, Riscos e Benefícios. São Paulo: Editora Harbra, 1988.

OKUNO, Emico et al. Física das Radiações. São Paulo: Editora Oficina de Texto, 2010.

PAULINO-LIMA, I. G. Investigação das condições de sobrevivência de microrganismos extremófilos em ambientes extraterrestres simulados. 2010. 256 f. Tese (Doutorado em Ciências Biomédicas) - Instituto de Ciências Biomédicas, Universidade Federal do Rio de Janeiro, Rio de Janeiro, 2010.

PELCZAR JÚNIOR, M. J.; CHAN, E. C. S.; KRIEG, N. R. Microbiologia: conceitos e aplicações. São Paulo: Makron Books, v. 1, p. 542, 1996.

POTERA, C. What is radiation's true target? Environmental Health Perspectives. v. 115, n. 8, p. 402A, 2007.

RAMSAY, J.; BIRRELL, G. Normal tissue radiosensitivity in breast cancer patients. Int. J. Radiat. Oncol. Biol. Phys., v. 31, p. 339-344, 1995.

REPACHOLI, M. H.; GREENEBAUM, B. Interaction of Static and Extremely Low Frequency Electric and Magnetic Fields with Living Sytems: Health Effects and Research Needs. Bioelectromagnetics, v. 20, p. 133-160, 1999.

ROTHSCHILD, L. J.; MANCINELLI, R. L. Life in extreme environments. Nature, v. 409, n. 6823, p. 1092-1101, 2001.

SAMBROOK, J.; RUSSELL, D. W. Molecular Cloning a laboratory manual. New York: Cold Spring Harbor Laboratory Press, 2001. 
SILVA, E. C. Controle Populacional de Microcystis panniformis (Cyanobacteria) utilizando radiações ionizantes e outros agentes físicos exogenous. 2006. 84 f. Dissertação (Mestrado em Biotecnologia) - Instituto de Ciências Biomédicas, Universidade de São Paulo, São Paulo, 2006.

SGHAIER, H.; NARUMI, I.; SATOH, K.; OHBA, H.; MITOMO, H. Problems with the current deinococcal hypothesis: An alternative theory. Theory in Biosciences, v. 126, p. 43-45, 2007.

SUKHI, S. S.; SHASHIDHAR, R.; SANJUKTA, L., KUMAR, A.; BANDEKAR, J. $\mathrm{R}$. Radiation resistance of Deinococcus radiodurans R1with respect to growth phase. Food Technology Division, Bhabha Atomic Research Centre, Trombay, Mumbai, India; and 2Analytical Chemistry Division, Bhabha Atomic Research Centre, Trombay, Mumbai, India. FEMS Microbiol. Lett., v. 297, p. 49-53, 2009.

TAKASHIMA, Y.; IKEHATA, M.; MIYAKOSHI, J.; KOANA, T. Inhibition of UVinduced $\mathrm{G} 1$ arrest by exposure to $50 \mathrm{~Hz}$ magnetic fields in repair-proficient and -deficient yeast strains. Int. J. Radiat. Biol., v. 79, p. 919-924, 2003.

TELLÓ, M.; RAIZER, A.; BUZAID, A. C.; DOMENGE, C.; DIAS, G. A. D.; ALMAGUER, H. D.; OLIVEIRA, L. O.; FARBER, P. L.; OLIVEIRA, R. T.; SILVA, V. D. O uso da corrente elétrica no tratamento do câncer. Porto Alegre: Edipucrs, 2004.

TILMANN, D. M.; PAUL, S. Unexpected electrons. Nature Physics, v. 6, Feb, pp. 82 e 83, 2010.

TORTORA, G. J. F.; BERDELL, R. C.; CHISTINE, L. Microbiologia. 6th ed. Porto Alegre: Artmed, 2000.

TUITE, M. F.; OLIVER, S. G. Culture Systems. In: MATHEWS, T. M.; WEBB, C. Saccharomyces - Biotechnology Handbooks. 4th ed. New York: Plenum Press, 1991. Cap. 8.

WALLECZEK, J.; SHIU, E. C.; HAHN, G. M. Increase in radiation-induced HPRT gene mutation frequency after nonthermal exposure to nonionizing $60 \mathrm{~Hz}$ electromagnetic fields. Radiat. Res., v. 151, p. 489-497, 1999.

WERTHEIMER, N.; LEEPER, E. Electrical wiring configurations and childhood cancer. Am. J. Epidemiol., v. 109, p. 273-284, 1979.

WHITE, O. et al. Genoma Sequence of the Radioresistant Bacterium Deinococcus radiodurans R1. Science, v. 286, p. 1571, 1999.

PEREZ, C. A.; BRADY, L. W. Principles and practice of radiation oncology. Philadelphia: J. B. Lippincott, 1997. 
ZAHRADKA, K.; SLADE, D.; BAILONE, A.; SOMMER, S.; AVERBECK, D.; PETRANOVIC, M.; LINDNER, A. B.; RADMAN, M. Reassembly of shattered chromosomes in Deinococcus radiodurans. Nature, v. 443, p. 569-573, n. 5, Oct. 2006. 
Apêndíces 


\section{APÊNDICE A - Tabelas de Dados das Figuras}

\section{Tabelas}

Abaixo seguem as tabelas correspondentes às figuras apresentados no corpo desta tese. O número e texto da legenda de cada tabela correspondem ao que foi utilizado nas figuras acima.

\subsection{Tabelas das Curvas de Crescimento}

Tabela da Figura 19: Curvas de crescimento de D. radiodurans e E. coli, obtidas por medidas de DO e incerteza de $0,0001 \%$.

\begin{tabular}{c|c|c}
\cline { 2 - 3 } & D. radiodurans & E. coli \\
\hline TEMPO (h) & DO (600nm) & DO (600nm) \\
\hline 0 & 0,454 & 0,694 \\
\hline 1 & 0,624 & 1,345 \\
\hline 2 & 1,009 & 2,149 \\
\hline 3 & 1,362 & 2,912 \\
\hline 4 & 1,926 & 3,631 \\
\hline 5 & 2,088 & 4,232 \\
\hline 6 & 3,404 & 4,707 \\
\hline 7 & 5,963 & 5,770 \\
\hline 8 & 8,410 & 6,447 \\
\hline 9 & 11,919 & 6,402 \\
\hline 10 & 11,975 & 6,312 \\
\hline 11 & 11,986 & 6,212 \\
\hline 12 & 11,995 & 5,452 \\
\hline 14 & 14,351 & 3,752 \\
\hline 16 & 14,474 & 2,503 \\
\hline 18 & 14,431 & 1,734 \\
\hline 20 & 12,124 & 1,013 \\
\hline
\end{tabular}


Tabela da Figura 20: Curvas de crescimento da D. radiodurans e E. coli, obtidas por medidas de UFC/ml.

\begin{tabular}{|c|c|c|c|c|c|c|}
\hline & \multicolumn{3}{|c|}{ D. radiodurans } & \multicolumn{3}{|c|}{ E. coli } \\
\hline TEMPO (h) & $\mathrm{UFC} / \mathrm{ml}$ & $\begin{array}{c}\text { Qui- } \\
\text { Quadrado }\end{array}$ & $\begin{array}{c}\text { Desvio } \\
\text { da Média }\end{array}$ & $\mathrm{UFC} / \mathrm{ml}$ & $\begin{array}{c}\text { Qui- } \\
\text { Quadrado }\end{array}$ & $\begin{array}{c}\text { Desvio } \\
\text { da Média }\end{array}$ \\
\hline 0 & $0,0 \mathrm{E}+00$ & 1,00 & 0,47 & $0,0 \mathrm{E}+00$ & 2,72 & 6,00 \\
\hline 1 & $4,0 \mathrm{E}+07$ & 0,00 & 0,82 & $1,0 \mathrm{E}+08$ & 1,58 & 5,22 \\
\hline 2 & $7,0 \mathrm{E}+07$ & 0,00 & 1,15 & $2,5 \mathrm{E}+08$ & 1,75 & 4,96 \\
\hline 3 & $1,5 \mathrm{E}+08$ & 0,31 & 2,94 & $3,5 \mathrm{E}+08$ & 1,22 & 2,26 \\
\hline 4 & $2,7 \mathrm{E}+08$ & 0,27 & 7,21 & $5,5 \mathrm{E}+08$ & 1,03 & 7,63 \\
\hline 5 & $4,5 \mathrm{E}+08$ & 0,39 & 4,69 & $7,5 \mathrm{E}+08$ & 1,66 & 2,56 \\
\hline 6 & $7,5 \mathrm{E}+08$ & 0,22 & 10,44 & $1,0 \mathrm{E}+09$ & 0,05 & 2,21 \\
\hline 7 & - & - & - & $1,2 \mathrm{E}+09$ & 6,00 & 0,58 \\
\hline 8 & $1,5 \mathrm{E}+09$ & 1,75 & 3,40 & $1,3 \mathrm{E}+09$ & 0,08 & 2,83 \\
\hline 9 & - & & & $1,4 \mathrm{E}+09$ & 0,20 & 1,83 \\
\hline 10 & $2,0 \mathrm{E}+09$ & 0,98 & 4,12 & $1,3 \mathrm{E}+09$ & 2,29 & 2,16 \\
\hline 11 & - & - & - & $1,3 \mathrm{E}+09$ & 3,80 & 2,11 \\
\hline 12 & $2,2 \mathrm{E}+09$ & 0,98 & 4,12 & $1,2 \mathrm{E}+09$ & 0,67 & 2,00 \\
\hline 14 & $2,2 \mathrm{E}+09$ & 1,75 & 3,40 & $8,5 \mathrm{E}+08$ & 3,15 & 5,33 \\
\hline 16 & $2,2 \mathrm{E}+09$ & 0,98 & 4,12 & $6,0 \mathrm{E}+08$ & 2,70 & 4,47 \\
\hline 18 & $1,6 \mathrm{E}+09$ & 0,98 & 4,12 & $4,5 \mathrm{E}+08$ & 2,18 & 3,87 \\
\hline 20 & $1,2 \mathrm{E}+09$ & 1,75 & 3,40 & $3,6 \mathrm{E}+08$ & 1,22 & 3,50 \\
\hline & & 11,36 & & & 28,34 & \\
\hline
\end{tabular}

\subsection{Tabelas das Curvas de Sobrevivência}

Tabela da Figura 21: Curvas de sobrevivência da $D$. radiodurans nas fases estacionária e exponencial sob a ação de radiação gama.

\begin{tabular}{|c|c|c|c|c|c|c|c|c|}
\hline \multirow[b]{2}{*}{$\begin{array}{l}\text { DOSE } \\
\text { (kGy) }\end{array}$} & \multicolumn{4}{|c|}{ Fase Estacionária } & \multicolumn{4}{|c|}{ Fase Exponencial } \\
\hline & UFC/mL & $\%$ & $\begin{array}{c}\text { Qui- } \\
\text { Quadrado }\end{array}$ & $\begin{array}{c}\text { Desvio } \\
\text { da } \\
\text { Média }\end{array}$ & UFC/mL & $\%$ & $\begin{array}{c}\text { Qui- } \\
\text { Quadrado }\end{array}$ & $\begin{array}{c}\text { Desvio } \\
\text { da } \\
\text { Média }\end{array}$ \\
\hline 0 & $1,4 \mathrm{E}+09$ & 100,0 & 2,92 & 6,24 & $1,2 \mathrm{E}+08$ & 100,0 & 1,05 & 6,39 \\
\hline 1 & $1,4 \mathrm{E}+09$ & 99,3 & 2,20 & 6,88 & $8,4 \mathrm{E}+07$ & 67,9 & 2,17 & 5,27 \\
\hline 2 & $1,3 \mathrm{E}+09$ & 92,3 & 1,19 & 6,14 & $5,0 \mathrm{E}+07$ & 40,2 & 1,27 & 4,04 \\
\hline 3 & $1,2 \mathrm{E}+09$ & 84,9 & 1,38 & 7,82 & $2,9 \mathrm{E}+07$ & 23,6 & 1,49 & 3,02 \\
\hline 4 & $1,1 \mathrm{E}+09$ & 81,3 & 2,13 & 8,49 & $1,4 \mathrm{E}+07$ & 11,0 & 1,08 & 2,08 \\
\hline 5 & $1,0 \mathrm{E}+09$ & 73,9 & 2,41 & 7,18 & $1,1 \mathrm{E}+07$ & 8,9 & 1,19 & 1,89 \\
\hline 6 & $9,5 \mathrm{E}+08$ & 69,9 & 1,29 & 6,91 & $9,0 \mathrm{E}+06$ & 7,3 & 1,56 & 1,73 \\
\hline 7 & $9,0 \mathrm{E}+08$ & 66,2 & 1,24 & 5,93 & $7,5 \mathrm{E}+06$ & 6,1 & 1,65 & 1,60 \\
\hline 8 & $8,0 \mathrm{E}+08$ & 58,8 & 1,29 & 5,03 & $5,5 \mathrm{E}+06$ & 4,5 & 1,63 & 1,33 \\
\hline 9 & $5,0 \mathrm{E}+08$ & 36,8 & 1,18 & 3,38 & $3,5 \mathrm{E}+05$ & 0,3 & 1,27 & 1,11 \\
\hline 10 & $2,4 \mathrm{E}+08$ & 17,9 & 1,21 & 8,98 & $2,5 \mathrm{E}+04$ & 0,0 & 1,00 & 0,94 \\
\hline 11 & $9,00 \mathrm{E}+07$ & 6,6 & 1,11 & 5,73 & $2,50 E+03$ & 0,0 & 2,00 & 1,00 \\
\hline 12 & $4,40 \mathrm{E}+07$ & 3,2 & 1,14 & 3,84 & $2,00 E+03$ & 0,0 & 2,00 & 0,88 \\
\hline & & & 20,69 & & & & 19,34 & \\
\hline
\end{tabular}


Tabela da Figura 22: Curvas de sobrevivência da E. coli nas fases estacionária e exponencial sob a ação de radiação gama.

\begin{tabular}{|c|c|c|c|c|c|c|c|c|}
\hline \multirow[b]{2}{*}{$\begin{array}{l}\text { DOSE } \\
\text { (kGy) }\end{array}$} & \multicolumn{4}{|c|}{ Fase Estacionária } & \multicolumn{4}{|c|}{ Fase Exponencial } \\
\hline & $\mathrm{UFC} / \mathrm{mL}$ & $\%$ & $\begin{array}{c}\text { Qui- } \\
\text { Quadrado }\end{array}$ & $\begin{array}{l}\text { Desvio } \\
\text { da } \\
\text { Média }\end{array}$ & $\mathrm{UFC} / \mathrm{mL}$ & $\%$ & $\begin{array}{c}\text { Qui- } \\
\text { Quadrado }\end{array}$ & $\begin{array}{c}\text { Desvio } \\
\text { da } \\
\text { Média }\end{array}$ \\
\hline 0 & $1,8 \mathrm{E}+09$ & 100,0 & 1,24 & 7,72 & $1,3 \mathrm{E}+08$ & 100,00 & 2,29 & 6,60 \\
\hline 0,5 & $4,7 \mathrm{E}+06$ & 0,3 & 2,42 & 3,97 & $4,0 \mathrm{E}+04$ & 0,03 & 1,53 & 3,64 \\
\hline 1 & $2,0 \mathrm{E}+05$ & 0,0 & 1,46 & 8,19 & $5,5 \mathrm{E}+04$ & 0,00 & 1,35 & 4,29 \\
\hline 1,5 & $3,3 \mathrm{E}+04$ & 0,0 & 2,01 & 10,45 & $1,7 \mathrm{E}+03$ & 0,00 & 1,88 & 7,49 \\
\hline 2 & $6,0 \mathrm{E}+02$ & 0,0 & 1,01 & 4,48 & $1,4 \mathrm{E}+02$ & 0,00 & 1,51 & 2,13 \\
\hline 2,5 & $7,0 \mathrm{E}+01$ & 0,0 & 1,14 & 1,53 & $1,3 \mathrm{E}+01$ & 0,00 & 2,00 & 0,67 \\
\hline 3 & $1,0 \mathrm{E}+01$ & 0,0 & 2,00 & 0,58 & $0,0 \mathrm{E}+00$ & 0,00 & - & 0,00 \\
\hline 3,5 & $0,0 \mathrm{E}+00$ & 0,0 & - & 0,00 & $0,0 \mathrm{E}+00$ & 0,00 & - & 0,00 \\
\hline 4 & $0,0 \mathrm{E}+00$ & 0,0 & - & 0,00 & $0,0 \mathrm{E}+00$ & 0,00 & - & 0,00 \\
\hline & & & 11,29 & & & & 10,56 & \\
\hline
\end{tabular}

Tabela da Figura 23: Curvas de sobrevivência da $D$. radiodurans nas fases estacionária e exponencial sob a ação de radiação gama com ajuste na suspensão celular.

\begin{tabular}{c|c|c|c|c|c|c|c|c}
\cline { 2 - 9 } & \multicolumn{4}{|c|}{ Fase Estacionária } & \multicolumn{4}{c}{ Fase Exponencial } \\
\hline $\begin{array}{c}\text { DOSE } \\
\text { (kGy) }\end{array}$ & UFC/mL & $\%$ & $\begin{array}{c}\text { Qui- } \\
\text { Quadrado }\end{array}$ & $\begin{array}{c}\text { Desvio } \\
\text { da } \\
\text { Média }\end{array}$ & UFC/mL & $\%$ & $\begin{array}{c}\text { Qui- } \\
\text { Quadrado }\end{array}$ & $\begin{array}{c}\text { Desvio } \\
\text { da } \\
\text { Média }\end{array}$ \\
\hline 0 & $7,0 \mathrm{E}+08$ & 100,0 & 1,14 & 1,53 & $4,7 \mathrm{E}+08$ & 100,0 & 1,00 & 1,25 \\
\hline 2 & $6,7 \mathrm{E}+08$ & 95,2 & 1,30 & 1,49 & $4,3 \mathrm{E}+08$ & 92,9 & 1,86 & 3,80 \\
\hline 4 & $6,1 \mathrm{E}+08$ & 87,1 & 1,87 & 4,51 & $4,4 \mathrm{E}+08$ & 94,3 & 1,23 & 3,83 \\
\hline 6 & $6,0 \mathrm{E}+08$ & 86,2 & 2,30 & 4,48 & $3,8 \mathrm{E}+08$ & 81,4 & 2,53 & 3,56 \\
\hline 8 & $2,9 \mathrm{E}+08$ & 41,9 & 1,52 & 3,13 & $9,0 \mathrm{E}+08$ & 19,4 & 1,78 & 5,49 \\
\hline & & & 8,13 & & & & 8,39 & \multicolumn{1}{c}{}
\end{tabular}


Tabela da Figura 24: Curvas de sobrevivência de $D$. radidourans na fase estacionária, sob a ação de radiação gama e radiação gama + campo elétrico de $10 \mathrm{~h}$. Inserção: Gráfico Relativo $(y+C E / y)$ de $D$. radiodurans na fase estacionária, sob a ação de radiação gama e radiação gama + campo elétrico de $10 \mathrm{~h}$.

\begin{tabular}{|c|c|c|c|c|c|c|c|c|c|}
\hline & \multicolumn{4}{|c|}{ Gamas } & \multicolumn{4}{|c|}{ Gamas + CE } & \multirow{2}{*}{$\begin{array}{c}\text { Inserção } \\
R= \\
S(V+C E) / S(V)\end{array}$} \\
\hline $\begin{array}{c}\text { DOSE(k } \\
\text { Gy) }\end{array}$ & $\mathrm{UFC} / \mathrm{mL}$ & $\%$ & $\begin{array}{c}\text { Qui- } \\
\text { Quadrado }\end{array}$ & $\begin{array}{c}\text { Desvio } \\
\text { da Média }\end{array}$ & $\mathrm{UFC} / \mathrm{mL}$ & $\%$ & $\begin{array}{c}\text { Qui- } \\
\text { Quadrado }\end{array}$ & $\begin{array}{c}\text { Desvio } \\
\text { da Média }\end{array}$ & \\
\hline 0 & $1,4 \mathrm{E}+09$ & 100,0 & 2,92 & 6,24 & $5,6 \mathrm{E}+09$ & 100,0 & 2,89 & 4,32 & 1,00 \\
\hline 1 & $1,4 \mathrm{E}+09$ & 99,3 & 2,20 & 6,88 & & & & & - \\
\hline 2 & $1,3 \mathrm{E}+09$ & 92,3 & 1,19 & 6,14 & $4,7 E+09$ & 83,9 & 2,09 & 3,96 & 0,91 \\
\hline 3 & $1,2 \mathrm{E}+09$ & 84,9 & 1,38 & 7,82 & & & & & - \\
\hline 4 & $1,1 \mathrm{E}+09$ & 81,3 & 2,13 & 8,49 & $3,5 E+09$ & 62,5 & 1,43 & 3,42 & 0,77 \\
\hline 5 & $1,0 \mathrm{E}+09$ & 73,9 & 2,41 & 7,18 & & & & & - \\
\hline 6 & $9,5 \mathrm{E}+08$ & 69,9 & 1,29 & 6,91 & $1,6 \mathrm{E}+09$ & 27,9 & 2,19 & 7,21 & 0,40 \\
\hline 7 & $9,0 E+08$ & 66,2 & 1,24 & 5,93 & & & & & - \\
\hline 8 & $8,0 \mathrm{E}+08$ & 58,8 & 1,29 & 5,03 & $7,3 \mathrm{E}+08$ & 13,1 & 1,18 & 1.56 & 0,20 \\
\hline 9 & $5,0 \mathrm{E}+08$ & 36,8 & 1,18 & 3,38 & & & & & \\
\hline 10 & $2,4 \mathrm{E}+08$ & 17,9 & 1,21 & 8,98 & & & & & \\
\hline 11 & $9,00 \mathrm{E}+07$ & 6,6 & 1,11 & 5,73 & & & & & \\
\hline 12 & $4,40 \mathrm{E}+07$ & 3,2 & 1,14 & 3,84 & & & & & \\
\hline & & & 20,69 & & & & 9,78 & & \\
\hline
\end{tabular}

Tabela da Figura 25: Curvas de sobrevivência da $D$. radiodurans na fase exponencial, sob a ação de radiação gama e radiação gama + campo elétrico de $10 \mathrm{~h}$.

\begin{tabular}{|c|c|c|c|c|c|c|c|c|}
\hline \multirow[b]{3}{*}{$\begin{array}{l}\text { DOSE } \\
\text { (kGy) }\end{array}$} & \multicolumn{8}{|c|}{ Fase Exponencial } \\
\hline & \multicolumn{4}{|c|}{ Gamas } & \multicolumn{4}{|c|}{ Gamas + CE (10h) } \\
\hline & UFC/mL & $\%$ & $\begin{array}{c}\text { Qui- } \\
\text { Quadrado }\end{array}$ & $\begin{array}{c}\text { Desvio } \\
\text { da } \\
\text { Média }\end{array}$ & $\mathrm{UFC} / \mathrm{mL}$ & $\%$ & $\begin{array}{c}\text { Qui- } \\
\text { Quadrado }\end{array}$ & $\begin{array}{c}\text { Desvio } \\
\text { da } \\
\text { Média }\end{array}$ \\
\hline 0 & $1,2 \mathrm{E}+08$ & 100,0 & 1,05 & 6,39 & $5,4 \mathrm{E}+08$ & 100,0 & 1,33 & 4,24 \\
\hline 1 & $8,4 \mathrm{E}+07$ & 67,9 & 2,17 & 5,27 & & & & \\
\hline 2 & $5,0 \mathrm{E}+07$ & 40,2 & 1,27 & 4,04 & $2,3 E+08$ & 42,6 & 1,13 & 2,77 \\
\hline 3 & $2,9 \mathrm{E}+07$ & 23,6 & 1,49 & 3,02 & & & & \\
\hline 4 & $1,4 \mathrm{E}+07$ & 11,0 & 1,08 & 2,08 & $2,8 \mathrm{E}+07$ & 5,1 & 2,19 & 3,04 \\
\hline 5 & $1,1 \mathrm{E}+07$ & 8,9 & 1,19 & 1,89 & & & & \\
\hline 6 & $9,0 \mathrm{E}+06$ & 7,3 & 1,56 & 1,73 & $1,1 \mathrm{E}+07$ & 1,9 & 2,31 & 1,89 \\
\hline 7 & $7,5 \mathrm{E}+06$ & 6,1 & 1,65 & 1,60 & & & & \\
\hline 8 & $5,5 \mathrm{E}+06$ & 4,5 & 1,63 & 1,33 & $8,5 \mathrm{E}+05$ & 0,2 & 2,85 & 1,70 \\
\hline 9 & $3,5 \mathrm{E}+05$ & 0,3 & 1,27 & 1,11 & & & & \\
\hline 10 & $2,5 \mathrm{E}+04$ & 0,0 & 1,00 & 0,94 & & & & \\
\hline 11 & $2,50 \mathrm{E}+03$ & 0,0 & 2,00 & 1,00 & & & & \\
\hline 12 & $2,00 \mathrm{E}+03$ & 0,0 & 2,00 & 0,88 & & & & \\
\hline & & & 19,34 & & & & 9,82 & \\
\hline
\end{tabular}


Tabela da Figura 26: Curvas de sobrevivência da $D$. radiodurans nas fases estacionária e exponencial, sob a ação de radiação gama combinada com campo elétrico de $10 \mathrm{~h}$.

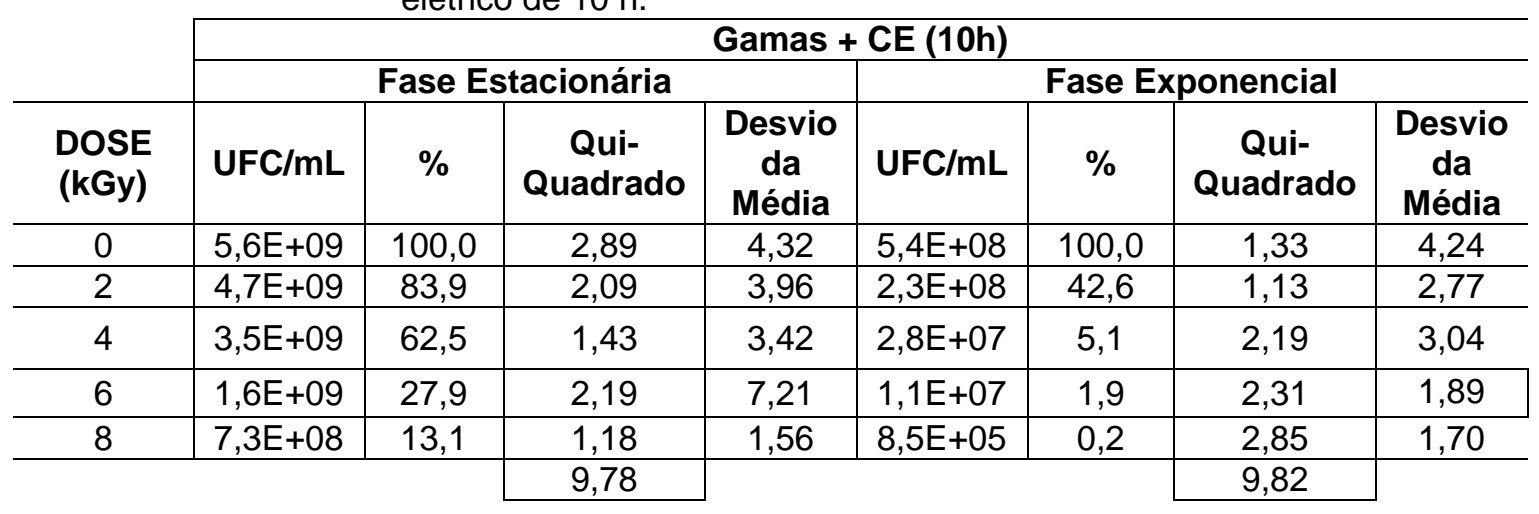

Tabela da Figura 30: Curvas de sobrevivência da $D$. radiodurans na fase exponencial, sob a ação de radiação gama e radiação gama combinada com campo magnético por $10 \mathrm{~h}$.

\begin{tabular}{|c|c|c|c|c|c|c|c|c|}
\hline \multirow[b]{3}{*}{$\begin{array}{l}\text { DOSE } \\
\text { (kGy) }\end{array}$} & \multicolumn{8}{|c|}{ Fase Exponencial } \\
\hline & \multicolumn{4}{|c|}{ Gamas } & \multicolumn{4}{|c|}{ Gamas + CM (10h) } \\
\hline & $\mathrm{UFC} / \mathrm{mL}$ & $\%$ & $\begin{array}{c}\text { Qui- } \\
\text { Quadrado }\end{array}$ & $\begin{array}{c}\text { Desvio } \\
\text { da } \\
\text { Média }\end{array}$ & $\mathrm{UFC} / \mathrm{mL}$ & $\%$ & $\begin{array}{c}\text { Qui- } \\
\text { Quadrado }\end{array}$ & $\begin{array}{c}\text { Desvio } \\
\text { da } \\
\text { Média }\end{array}$ \\
\hline 0 & $1,2 \mathrm{E}+08$ & 100,0 & 1,05 & 6,39 & 0 & $5,4 \mathrm{E}+08$ & 100,0 & 1,63 \\
\hline 1 & $8,4 \mathrm{E}+07$ & 67,9 & 2,17 & 5,27 & & & & \\
\hline 2 & $5,0 \mathrm{E}+07$ & 40,2 & 1,27 & 4,04 & 2 & $4,2 \mathrm{E}+08$ & 76,7 & 2,51 \\
\hline 3 & $2,9 \mathrm{E}+07$ & 23,6 & 1,49 & 3,02 & & & & \\
\hline 4 & $1,4 \mathrm{E}+07$ & 11,0 & 1,08 & 2,08 & 4 & $3,8 \mathrm{E}+08$ & 69,9 & 1,42 \\
\hline 5 & $1,1 \mathrm{E}+07$ & 8,9 & 1,19 & 1,89 & & & & \\
\hline 6 & $9,0 \mathrm{E}+06$ & 7,3 & 1,56 & 1,73 & 6 & $2,2 \mathrm{E}+08$ & 41,1 & 2,18 \\
\hline 7 & $7,5 \mathrm{E}+06$ & 6,1 & 1,65 & 1,60 & & & & \\
\hline 8 & $5,5 \mathrm{E}+06$ & 4,5 & 1,63 & 1,33 & 8 & $1,3 \mathrm{E}+08$ & 24,2 & 1,86 \\
\hline 9 & $3,5 \mathrm{E}+05$ & 0,3 & 1,27 & 1,11 & & & & \\
\hline 10 & $2,5 \mathrm{E}+04$ & 0,0 & 1,00 & 0,94 & & & & \\
\hline 11 & $2,50 \mathrm{E}+03$ & 0,0 & 2,00 & 1,00 & & & & \\
\hline 12 & $2,00 \mathrm{E}+03$ & 0,0 & 2,00 & 0,88 & & & & \\
\hline & & & 19,34 & & & & 9,61 & \\
\hline
\end{tabular}


Tabela da Figura 31: Curvas de sobrevivência de $D$. radidourans na fase estacionária, sob a ação de radiação gama e radiação gama + campo magnético de $10 \mathrm{~h}$. Inserção: Gráfico Relativo $(\gamma+\mathrm{CM} / \mathrm{\gamma})$ de $D$. radiodurans na fase estacionária, sob a ação de radiação gama e radiação gama + campo magnético de $10 \mathrm{~h}$.

\begin{tabular}{|c|c|c|c|c|c|c|c|c|c|}
\hline \multirow[b]{2}{*}{ DOSE(kGy) } & \multicolumn{4}{|c|}{ Gamas } & \multicolumn{4}{|c|}{ Gamas + CM } & \multirow{2}{*}{$\begin{array}{c}\text { Inserção } \\
R= \\
S(V+C E) / S(V)\end{array}$} \\
\hline & $\mathrm{UFC} / \mathrm{mL}$ & $\%$ & $\begin{array}{c}\text { Qui- } \\
\text { Quadrado }\end{array}$ & $\begin{array}{c}\text { Desvio } \\
\text { da Média }\end{array}$ & $\mathrm{UFC} / \mathrm{mL}$ & $\%$ & $\begin{array}{c}\text { Qui- } \\
\text { Quadrado }\end{array}$ & $\begin{array}{c}\text { Desvio } \\
\text { da Média }\end{array}$ & \\
\hline 0 & $1,4 \mathrm{E}+09$ & 100,0 & 2,92 & 6,24 & $5,6 \mathrm{E}+09$ & 100,0 & 2,89 & 4,32 & 1,00 \\
\hline 1 & $1,4 \mathrm{E}+09$ & 99,3 & 2,20 & 6,88 & & & & & \\
\hline 2 & $1,3 E+09$ & 92,3 & 1,19 & 6,14 & $4,0 \mathrm{E}+09$ & 72,0 & 1,70 & 3,67 & 0,77 \\
\hline 3 & $1,2 \mathrm{E}+09$ & 84,9 & 1,38 & 7,82 & & & & & \\
\hline 4 & $1,1 \mathrm{E}+09$ & 81,3 & 2,13 & 8,49 & $3,5 \mathrm{E}+09$ & 63,1 & 1,26 & 3,43 & 0,77 \\
\hline 5 & $1,0 \mathrm{E}+09$ & 73,9 & 2,41 & 7,18 & & & & & \\
\hline 6 & $9,5 \mathrm{E}+08$ & 69,9 & 1,29 & 6,91 & $3,3 \mathrm{E}+09$ & 59,5 & 1,34 & 3,33 & 0,83 \\
\hline 7 & $9,0 \mathrm{E}+08$ & 66,2 & 1,24 & 5,93 & & & & & \\
\hline 8 & $8,0 \mathrm{E}+08$ & 58,8 & 1,29 & 5,03 & $1,3 \mathrm{E}+09$ & 23,5 & 1,86 & 6,62 & 0,40 \\
\hline 9 & $5,0 \mathrm{E}+08$ & 36,8 & 1,18 & 3,38 & & & & & \\
\hline 10 & $2,4 \mathrm{E}+08$ & 17,9 & 1,21 & 8,98 & & & & & \\
\hline 11 & $9,00 E+07$ & 6,6 & 1,11 & 5,73 & & & & & \\
\hline 12 & $4,40 E+07$ & 3,2 & 1,14 & 3,84 & & & & & \\
\hline & & & 20,69 & & & & 9,06 & & \\
\hline
\end{tabular}

Tabela da Figura 33: Curvas de sobrevivência da $D$. radiodurans na fase exponencial e estacionária, sob a ação de elétrons.

\begin{tabular}{|c|c|c|c|c|c|c|c|c|}
\hline \multirow[b]{2}{*}{$\begin{array}{l}\text { DOSE } \\
\text { (kGy) }\end{array}$} & \multicolumn{4}{|c|}{ Fase Estacionária } & \multicolumn{4}{|c|}{ Fase Exponencial } \\
\hline & UFC/mL & $\%$ & $\begin{array}{c}\text { Qui- } \\
\text { Quadrado }\end{array}$ & $\begin{array}{c}\text { Desvio } \\
\text { da } \\
\text { Média }\end{array}$ & UFC/mL & $\%$ & $\begin{array}{c}\text { Qui- } \\
\text { Quadrado }\end{array}$ & $\begin{array}{c}\text { Desvio } \\
\text { da } \\
\text { Média }\end{array}$ \\
\hline 0 & $3,7 E+09$ & 100,0 & 2,22 & 11,10 & $3,8 \mathrm{E}+08$ & 100,00 & 1,49 & 11,07 \\
\hline 1 & $2,0 E+09$ & 53,7 & 2,61 & 8,13 & $2,6 \mathrm{E}+07$ & 6,88 & 2,15 & 2,94 \\
\hline 2 & $2,4 \mathrm{E}+08$ & 6,6 & 1,39 & 9,00 & $6,3 E+06$ & 1,67 & 3,87 & 4,57 \\
\hline 3 & $1,1 \mathrm{E}+08$ & 2,9 & 2,93 & 5,93 & $2,5 \mathrm{E}+05$ & 0,07 & 1,75 & 0,94 \\
\hline 4 & $1,7 \mathrm{E}+07$ & 0,5 & 1,06 & 2,38 & $1,0 \mathrm{E}+00$ & 0,00 & - & 0,00 \\
\hline 5 & $2,5 \mathrm{E}+05$ & 0,0 & 3,03 & 2,87 & $1,0 \mathrm{E}+00$ & 0,00 & - & 0,00 \\
\hline 6 & $5,7 E+03$ & 0,0 & 0,82 & 1,37 & $1,0 \mathrm{E}+00$ & 0,00 & - & 0,00 \\
\hline 7 & $7,8 \mathrm{E}+02$ & 0,0 & 1,86 & 5,09 & $1,0 \mathrm{E}+00$ & 0,00 & - & 0,00 \\
\hline 8 & $4,7 \mathrm{E}+01$ & 0,0 & 1,00 & 1,25 & $1,0 \mathrm{E}+00$ & 0,00 & - & 0,00 \\
\hline 9 & $1,0 \mathrm{E}+01$ & 0,0 & 2,00 & 0,58 & $1,0 \mathrm{E}+00$ & 0,00 & - & 0,00 \\
\hline 10 & $1,0 \mathrm{E}+01$ & 0,0 & 2,00 & 0,58 & $1,0 \mathrm{E}+00$ & 0,00 & - & 0,00 \\
\hline 11 & $0,0 \mathrm{E}+00$ & 0,0 & - & 0,00 & $1,0 \mathrm{E}+00$ & 0,00 & - & 0,00 \\
\hline 12 & $0,0 \mathrm{E}+00$ & 0,0 & - & 0,00 & $1,0 \mathrm{E}+00$ & 0,00 & - & 0,00 \\
\hline & & & 20,92 & & & & 9,27 & \\
\hline
\end{tabular}


Tabela da Figura 34: Curvas de sobrevivência da $D$. radiodurans na fase exponencial, sob a ação de gama e elétrons.

\begin{tabular}{|c|c|c|c|c|c|c|c|c|}
\hline \multirow[b]{2}{*}{$\begin{array}{l}\text { DOSE } \\
\text { (kGy) }\end{array}$} & \multicolumn{4}{|c|}{ Elétrons } & \multicolumn{4}{|c|}{ Gamas } \\
\hline & UFC/mL & $\%$ & $\begin{array}{c}\text { Qui- } \\
\text { Quadrado }\end{array}$ & $\begin{array}{l}\text { Desvio } \\
\text { da } \\
\text { Média } \\
(\%)\end{array}$ & UFC/mL & $\%$ & $\begin{array}{c}\text { Qui- } \\
\text { Quadrado }\end{array}$ & $\begin{array}{l}\text { Desvio } \\
\text { da } \\
\text { Média } \\
(\%)\end{array}$ \\
\hline 0 & $3,8 \mathrm{E}+08$ & 100,00 & 1,49 & 11,07 & $1,2 \mathrm{E}+08$ & 100,0 & 1,05 & 6,39 \\
\hline 1 & $2,6 \mathrm{E}+07$ & 6,88 & 2,15 & 2,94 & $8,4 \mathrm{E}+07$ & 67,9 & 2,17 & 5,27 \\
\hline 2 & $6,3 \mathrm{E}+06$ & 1,67 & 3,87 & 4,57 & $5,0 \mathrm{E}+07$ & 40,2 & 1,27 & 4,04 \\
\hline 3 & $2,5 \mathrm{E}+05$ & 0,07 & 1,75 & 0,94 & $2,9 \mathrm{E}+07$ & 23,6 & 1,49 & 3,02 \\
\hline 4 & $1,0 \mathrm{E}+00$ & 0,00 & - & 0,00 & $1,4 \mathrm{E}+07$ & 11,0 & 1,08 & 2,08 \\
\hline 5 & $1,0 \mathrm{E}+00$ & 0,00 & - & 0,00 & $1,1 \mathrm{E}+07$ & 8,9 & 1,19 & 1,89 \\
\hline 6 & $1,0 \mathrm{E}+00$ & 0,00 & - & 0,00 & $9,0 \mathrm{E}+06$ & 7,3 & 1,56 & 1,73 \\
\hline 7 & $1,0 \mathrm{E}+00$ & 0,00 & - & 0,00 & $7,5 \mathrm{E}+06$ & 6,1 & 1,65 & 1,60 \\
\hline 8 & $1,0 \mathrm{E}+00$ & 0,00 & - & 0,00 & $5,5 \mathrm{E}+06$ & 4,5 & 1,63 & 1,33 \\
\hline 9 & $1,0 \mathrm{E}+00$ & 0,00 & - & 0,00 & $3,5 \mathrm{E}+05$ & 0,3 & 1,27 & 1,11 \\
\hline 10 & $1,0 \mathrm{E}+00$ & 0,00 & - & 0,00 & $2,5 \mathrm{E}+04$ & 0,0 & 1,00 & 0,94 \\
\hline 11 & $1,0 \mathrm{E}+00$ & 0,00 & - & 0,00 & $2,50 \mathrm{E}+03$ & 0,0 & 2,00 & 1,00 \\
\hline 12 & $1,0 \mathrm{E}+00$ & 0,00 & - & 0,00 & $2,00 E+03$ & 0,0 & 2,00 & 0,88 \\
\hline & & & 9,27 & & & & 19,34 & \\
\hline
\end{tabular}

Tabela da Figura 35: Curvas de sobrevivência da $D$. radiodurans na fase estacionária, sob a ação de gama e elétrons.

\begin{tabular}{|c|c|c|c|c|c|c|c|c|}
\hline \multirow[b]{2}{*}{$\begin{array}{l}\text { DOSE } \\
\text { (kGy) }\end{array}$} & \multicolumn{4}{|c|}{ Elétrons } & \multicolumn{4}{|c|}{ Gamas } \\
\hline & $\mathrm{UFC} / \mathrm{mL}$ & $\%$ & $\begin{array}{c}\text { Qui- } \\
\text { Quadrado }\end{array}$ & $\begin{array}{l}\text { Desvio } \\
\text { da } \\
\text { Média } \\
(\%)\end{array}$ & UFC/mL & $\%$ & $\begin{array}{c}\text { Qui- } \\
\text { Quadrado }\end{array}$ & $\begin{array}{l}\text { Desvio } \\
\text { da } \\
\text { Média } \\
(\%)\end{array}$ \\
\hline 0 & $3,7 \mathrm{E}+09$ & 100,0 & 2,22 & 11,10 & $1,4 \mathrm{E}+09$ & 100,0 & 2,92 & 6,24 \\
\hline 1 & $2,0 \mathrm{E}+09$ & 53,7 & 2,61 & 8,13 & $1,4 \mathrm{E}+09$ & 99,3 & 2,20 & 6,88 \\
\hline 2 & $2,4 \mathrm{E}+08$ & 6,6 & 1,39 & 9,00 & $1,3 \mathrm{E}+09$ & 92,3 & 1,19 & 6,14 \\
\hline 3 & $1,1 \mathrm{E}+08$ & 2,9 & 2,93 & 5,93 & $1,2 \mathrm{E}+09$ & 84,9 & 1,38 & 7,82 \\
\hline 4 & $1,7 \mathrm{E}+07$ & 0,5 & 1,06 & 2,38 & $1,1 \mathrm{E}+09$ & 81,3 & 2,13 & 8,49 \\
\hline 5 & $2,5 \mathrm{E}+05$ & 0,0 & 3,03 & 2,87 & $1,0 \mathrm{E}+09$ & 73,9 & 2,41 & 7,18 \\
\hline 6 & $5,7 \mathrm{E}+03$ & 0,0 & 0,82 & 1,37 & $9,5 \mathrm{E}+08$ & 69,9 & 1,29 & 6,91 \\
\hline 7 & $7,8 \mathrm{E}+02$ & 0,0 & 1,86 & 5,09 & $9,0 E+08$ & 66,2 & 1,24 & 5,93 \\
\hline 8 & $4,7 \mathrm{E}+01$ & 0,0 & 1,00 & 1,25 & $8,0 \mathrm{E}+08$ & 58,8 & 1,29 & 5,03 \\
\hline 9 & $1,0 \mathrm{E}+01$ & 0,0 & 2,00 & 0,58 & $5,0 \mathrm{E}+08$ & 36,8 & 1,18 & 3,38 \\
\hline 10 & $1,0 \mathrm{E}+01$ & 0,0 & 2,00 & 0,58 & $2,4 \mathrm{E}+08$ & 17,9 & 1,21 & 8,98 \\
\hline 11 & $0,0 \mathrm{E}+00$ & 0,0 & - & 0,00 & $9,0 \mathrm{E}+07$ & 6,6 & 1,11 & 5,73 \\
\hline 12 & $0,0 \mathrm{E}+00$ & 0,0 & - & 0,00 & $4,4 \mathrm{E}+07$ & 3,2 & 1,14 & 3,84 \\
\hline & & & 20,92 & & & & 20,69 & \\
\hline
\end{tabular}


Tabela da Figura 36: Curvas de sobrevivência de E. coli nas fases exponencial e estacionária sob ação combinada de elétrons. Inserção: Curvas de sobrevivência da $E$. coli nas fases exponencial e estacionária, sob a ação de elétrons, escala linear-log.

\begin{tabular}{c|c|c|c|c|c|c|c|c}
\hline & \multicolumn{4}{|c|}{ Fase Estacionaria } & \multicolumn{5}{c}{ Fase Exponencial } \\
\hline DOSE & UFC/mL & $\%$ & $\begin{array}{c}\text { Qui- } \\
\text { Qua }\end{array}$ & $\begin{array}{c}\text { Desvio } \\
\text { da } \\
\text { Média } \\
(\%)\end{array}$ & UFC/mL & $\%$ & $\begin{array}{c}\text { Qui- } \\
\text { Qua }\end{array}$ & $\begin{array}{c}\text { Desvio } \\
\text { da } \\
\text { Média } \\
\text { (\%) }\end{array}$ \\
\hline 0 & $1,9 \mathrm{E}+08$ & 100,00 & 2,05 & 7,91 & $1,1 \mathrm{E}+08$ & 100,00 & 2,16 & 5,99 \\
\hline 0,57 & $4,8 \mathrm{E}+06$ & 2,58 & 1,92 & 4,01 & $2,4 \mathrm{E}+06$ & 2,20 & 1,83 & 9,48 \\
\hline 1,14 & $2,0 \mathrm{E}+05$ & 0,11 & 2,37 & 8,16 & $2,4 \mathrm{E}+06$ & 2,20 & 2,68 & 8,25 \\
\hline 1,71 & $3,3 \mathrm{E}+04$ & 0,02 & 2,36 & 10,45 & $2,0 \mathrm{E}+05$ & 0,19 & 3,52 & 10,44 \\
\hline 2,28 & $6,2 \mathrm{E}+02$ & 0,00 & 2,10 & 4,56 & $3,3 \mathrm{E}+04$ & 0,03 & 2,34 & 4,45 \\
\hline 2,85 & $8,3 \mathrm{E}+01$ & 0,00 & 2,24 & 1,67 & $6,1 \mathrm{E}+02$ & 0,00 & 1,14 & 1,53 \\
\hline 3,42 & $1,0 \mathrm{E}+01$ & 0,00 & 2,00 & 0,58 & $7,0 \mathrm{E}+01$ & 0,00 & 2,00 & 0,58 \\
\hline 3,99 & $0,0 \mathrm{E}+00$ & 0,00 & - & 0,00 & $7,0 \mathrm{E}+01$ & 0,00 & - & 0,00 \\
\hline
\end{tabular}

